
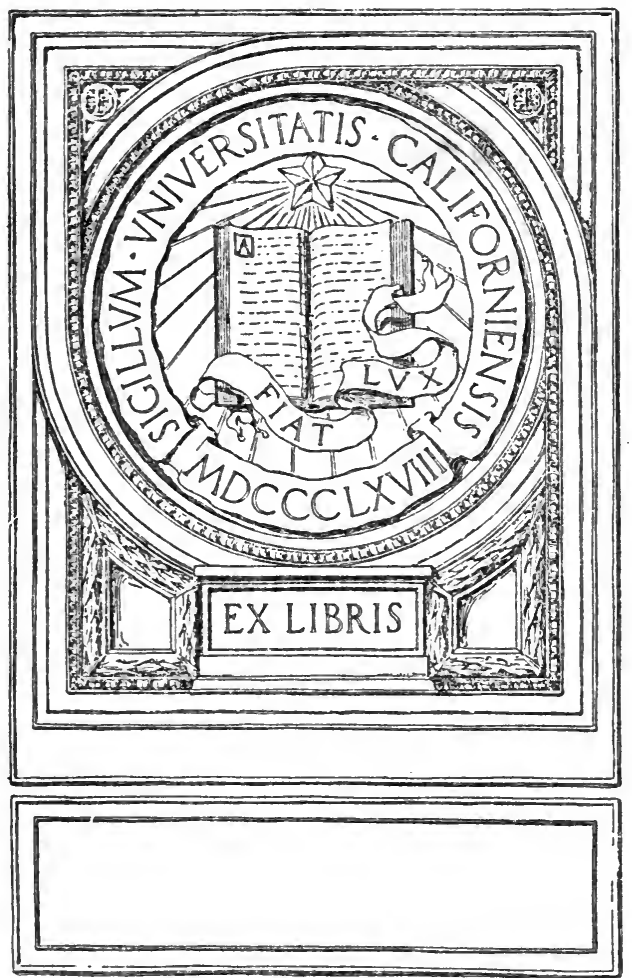

Digitized by the Internet Archive in 2007 with funding from Microsoft Corporation 
PERSONAL REMINISCENCES OF PRINCE BISMARCK 



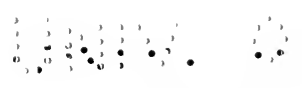




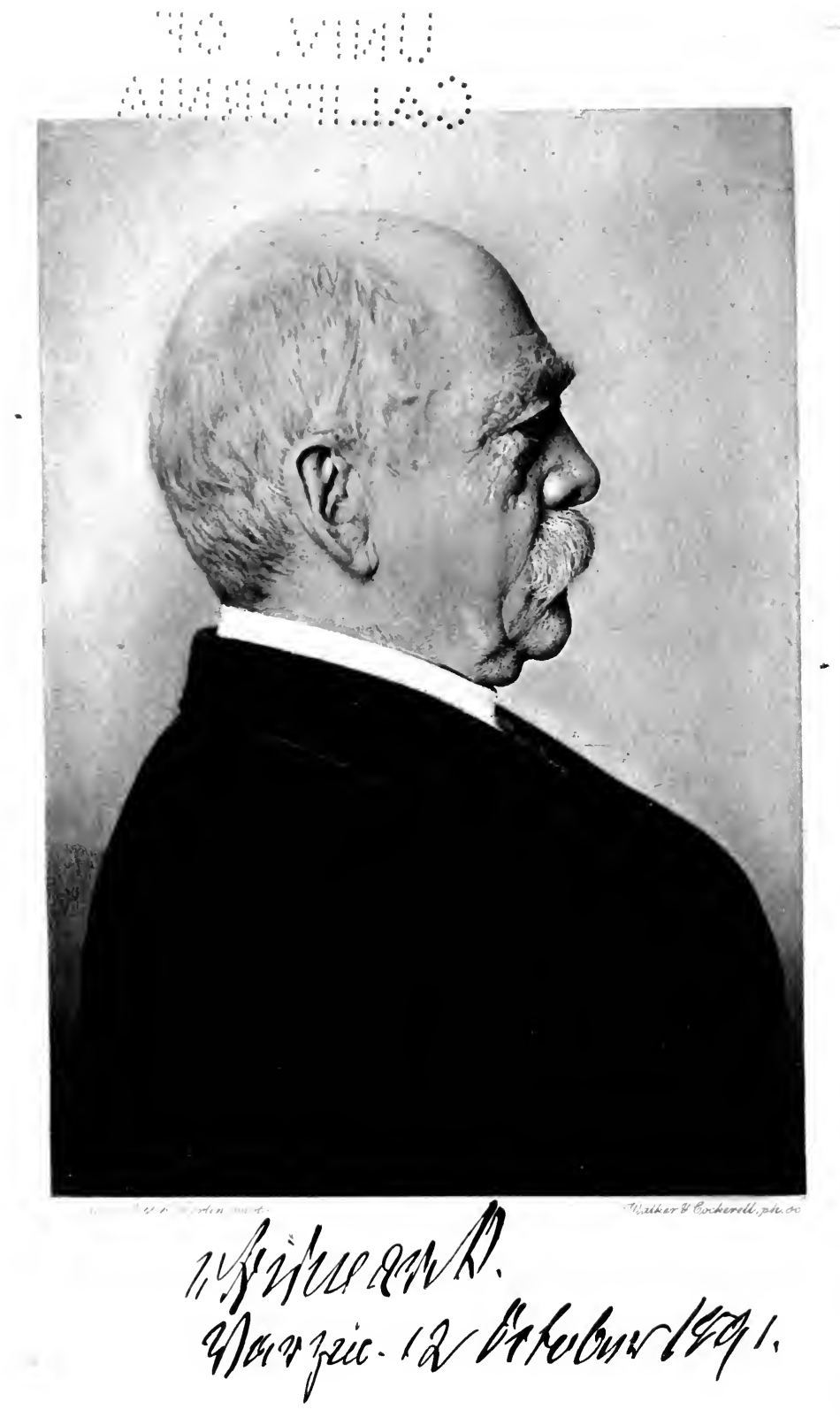




\section{PERSONAL REVINISCENCES OF PRINCE BISMARCK}

BY SIDNEY WHITMAN

\footnotetext{
"In his composition there was something of the tenderness of the woman, much of the naïveté of the child, and all the qualities of the man."
}

WITH A PORTRAIT

LONDON

JOHN MURRAY, ALBEMARLE STREET, W. 


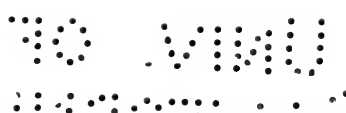

$$
12^{218}
$$


MY FRIEND

FRANZ VON ' LENBACH 


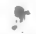

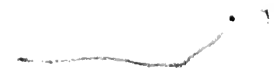

n.
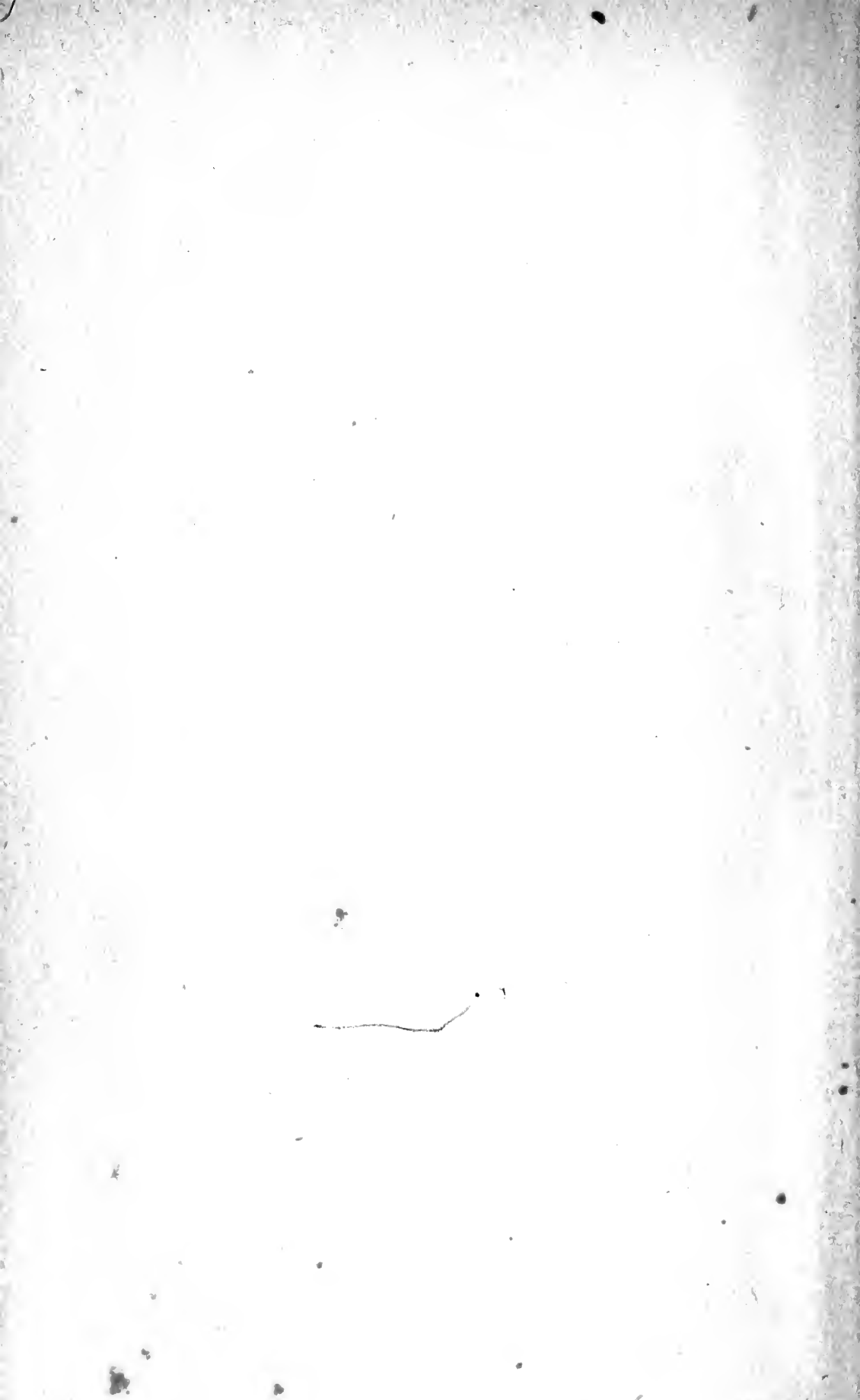

it

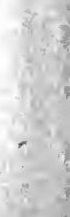




\section{PREFACE}

GHORTLY after Prince Bismarck's death a $\sim$ distinguished German Parliamentarian wrote a series of essays dealing with the personality and career of the deceased statesman. In the course of these he declared that nothing concerning Prince Bismarck is too trivial to be worth knowing and preserving. The man who expressed this view was not a partisan of the Unifier of Germany; on the contrary, he was an unsparing, even ungenerous critic. Such an opinion from such a source affords me some justification for the belief that my recollections of Prince ${ }^{\star}$ Bismarck may prove of interest.

In view of the fragmentary character of such compilations, I have added a short Introduction of a personal nature. It may assist the reader to enter into my train of thought, and thus to judge fairly of my standpoint.

LONDON

S. W.

Sept., 1902 



\section{CONTENTS}

CHAPTER I.

INTRODUCTION-PERSONAL . . . PAGE

CHAPTER II.

First Visit to Prince Bismarck (APril, i89I) . . 9

CHAPTER III.

First Visit to FriedrichsRuh (continued) • $\quad$ • 29

CHAPTER IV.

Visit to Schoenhausen (August, I891) . . . 43

CHAPTER V.

VISIT to VARzIN (OCTOBER, I89I) • * . . 62

CHAPTER VI.

VISIT TO VARzIN (continued) . . . . . . . $80^{\circ}$

CHAPTER VII.

VISIT TO VARzIN (concluded) . $\quad . \quad \ldots \quad . \quad$. $\quad . \quad$ IO8

CHAPTER VIII.

VISIT TO FRIEDRICHSRUH (JANUARY, 1892) . . . . 133

CHAPTER IX.

VISIT TO FRIEDRICHSRUH (MAY, I892) . . . 155 
CHAPTER $\mathrm{X}$.

Visit to Prince Bismarck at Kissingen (JUly, 1892) . 168

CHAPTER XI.

BISMARCK'S BIRTHDAY, (APRIL IST, I893) . . . 182

CHAPTER XII.

PRINCESS BISMARCK.

205

CHAPTER XIII.

BismarCK'S EIghtieth BIRTHDAY (APRIL IST, I895) . . 219

CHAPTER XIV.

VISIT TO FRIEDRICHSRUH (JUNE, I896)

CHAPTER XV.

BismaRCK'S Death (JUly 30Th, I898)

- 256

CHAPTER XVI.

FRIEDRICHSRUH (JULY, 1899)

. 270

CHAPTER XVII.

EPILEGOMENA

276

CHAPTER XVIII.

Conclusion

. $\quad$. $\quad . \quad 299$

INDEX 


\title{
PERSONAL REMINISCENCES OF PRINCE BISMARCK
}

\author{
CHAPTER I \\ INTRODUCTION-PERSONAL
}

W $\mathrm{Y}$ parents wished their children to learn VI German-a language of which nobody in our family-except my father, who was of German extraction-knew a word. I was therefore sent to Germany to school, where I remained four years -from 1859-63-part of which I spent at the Vitzthum Gymnasium in Dresden.

It is, I am sure, an error to suppose that we necessarily look back upon our school-days as the happiest period of our life. Both Prince Bismarck and Count Moltke, for instance, as is well known, recalled their school-days with repulsion. However, I am glad to say that in my own case it was otherwise, at least as far as my stay in Germany is concerned. For when arrived at manhood and business un a somewhat extensive scale brought me now and again back to that country, I used to love to spend 
my spare time: :vosifing. and lingering round the scenes of my boyhood. Gradually, in the course of years, a partiality for these youthful reminiscences grew into a deeper and more thoughtful appreciation of the people as well as the institutions of the country. It was no longer business alone, but many ties of friendship in different places and among various classes of the community which attracted me. I numbered among my friends and acquaintances the manufacturer, the artisan, the trader, the man of learning, the soldier, the noble in town and country, the diplomatist, the priest, the cardinal. I got to know them all, and to discover something human and congenial in each.

Again and again I visited Germany in the north and in the south, in the east and in the west, particularly in the dead centre, among the sombre forests of Thuringia. I climbed to the Wartburg, breathed the atmosphere of Tannhäuser and the Minnesänger as well as of the Reformation, culling memories on the spot of Dr. Martinus Luther. Standing in the little cell on the hill in which the reformer lived for years and translated the Bible, it was not difficult to conjure up the words of the renowned landsknecht leader, Georg von Frundsberg, to Luther at the Diet of Worms: "Little monk, little monk, thou goest on an errand such as neither I nor many a captain-even in the grimmest battleline-has ever undertaken. If, however, thou art in thy right mind and sure of thy case, go forward in God's name and be of good cheer; God will not 
desert thee." These very words might have been addressed to the political reformer of Germany as well. For they embody the "Categorical Imperative" in both cases, in both ages-for all time in the affairs of man: the free and full stake of a strong personality in the service of a great cause.

My German experiences extended through many years and increased my predilection, not so much perhaps for the individual as for the simple social life, and above all, the comparatively high standard of humanising culture and conduct, what the Germans themselves call "Sitte und Bildung," to be found even under a rough exterior, more or less wherever the German tongue is spoken. The poet was pointed out to me who had declined the pension of a king; I met the historian who had refused to collaborate with an emperor; as also the soldier who had led a million armed men to victory, and who had yet remained a simple-hearted man, content in old age to claim, like Goethe's Faust, the status of a peasant.

It was more particularly the epoch-making events of our time which stirred the blood and called forth my admiration for the eminent men who had directed them and thereby safe-guarded for all measurable time the independence, the dignity of the country. And here I may say that this was also the case with many Englishmen, a few of whom knew at least something about Germany without necessarily having, like myself, any German blood in their veins. This was at all times a 
poor guarantee for harbouring German sympathies. They saw, as I humbly thought I did, in the rise of Germany and her emancipation from outside influences, a crowning instance of the Nemesis of history; a tardy justice towards the country which has done much, and suffered even more, in the cause of human progress. They anticipated no disadvantage to England in this, but rather, if properly understood, a positive gain; as also that the auspicious development of the Teutonic race could only have the effect of enlarging the area of peace, the rule of equity, the respect for international law: being thus productive of an increase of the sum total of human happiness and well-being in the world.

Thomas Carlyle was foremost among Englishmen of this opinion: and the experience of a lifetime since those days, notwithstanding the frenzy of envy, jealousy, and misrepresentation which, for the moment, seems to have seized upon the less responsible elements of both countries, has, in the main, not proved them to have been mistaken. At least the fact speaks for them that Germany is the only one of the Great Powers which has consistently kept the peace from 187 I down to close upon the end of the nineteenth century. Her victories during that eventful period of thirty years have been those of peaceful work-in science, industry, and commerce.

Carlyle openly gloried in the German successes of 1870 as destined to ensure the future of that 
Teuton "Tapferkeit" and "Biederkeit,"* which he had many years previously declared in his History of the French Revolution must not be allowed to perish.

Of well-known Englishmen with whom I have since come into personal contact who were of a similar opinion to Thomas Carlyle, I may cite the eminent Scottish Hellenist, the late Professor John Stuart Blackie, Professor James Anthony Froude, the historian, and Professor Goldwin Smith, of Toronto, who is still alive. Each of these last two distinguished men had at different times been Regius Professor of History at the University of Oxford and thus, independently of their distinction as writers, held positions of representative importance. Although belonging to opposite English political parties, they both welcomed the unification of Germany as a boon. Froude, in a letter to me dated June, I 894 , says :-

"My own age is passing away. Another is coming on with its own views. It will not go very far wrong if it learns to hold in honour Bismarck and such as Bismarck, whatever it may please to think of ..."

Goldwin Smith is even more explicit in his championship of Germany and her great statesman, as the following, which I publish with his permission, may tend to show. As testimonies of goodwill towards Germany and appreciation of the founder of her unity they speak for themselves whilst coming from one who wields considerable

* "Honour to you, O kinsman; and may the old Deutsch Biederkeit and Tapferkeit, and valour which is Worth and Truth, be they Swiss, be they Saxon, fail in no age."-Thomas CarLyLe, History of the French Revolution, vol. ii. book v. p. 255 . 
influence with political thinkers on both sides of the Atlantic they possess a distinct interest :-

$$
\begin{aligned}
& \text { "The Grange, Toronto, } \\
& \text { "March } 15 \text { th, } 1889 .
\end{aligned}
$$

"SIR,-I hope it is not presumptuous in a stranger to express to you the pleasure with which he has read your Imperial Germany, especially that part of it in which you do justice to Bismarck. Bismarck has faults, no doubt, but they are only the almost inseparable concomitants of qualities, without which his wonderful work could not have been done. This work, unless weakness and want of patriotism wreck it, will be the great man's enduring monument when petty criticism has died away. . . .

"Yours faithfully,

"Goldwin SMITH."

Again, under date of May 7th, I889, Professor Goldwin Smith wrote me the following concerning Bismarck and Germany :-

"Bismarck was a fortunate combination of Liberalism and Militarism-tendencies usually discordant.

"This made him the man to eject Austria, overturn the Hanoverian Dynasty, unite Germany, save United Germany from France, and Europe from French ambition. I do not pretend to be a diplomatist ; but it has always seemed to me that in the German Alliance lay the diplomatic salvation of England ; . . The friendship of Germany in Europe brings with it to England the sympathy of that German element which is a very potent factor in the politics of the United States."

Among my German friends during a quarter of a century I may mention the late Dr. Ernst Engel. $\mathrm{He}$ was the founder of the Prussian Statistical Seminary, for many years the head of the model 
Statistical Bureau at Berlin, and took rank as the most distinguished of German-perhaps of European-statisticians.

Dr. Engel was ultimately forced to retire into private life in consequence of a difference with Prince Bismarck, of whom, as a staunch Radical, he had been a life-long opponent, and by whom, to his own thinking, he had been harshly treated. With a truly amiable and refined nature, Dr. Engel yet combined a distinct German vein of uncompromising contradiction. Thus, as we often held opposite views - as far as my diffidence may have ever allowed me to hold a decided view against so weighty an authority - we invariably found ample food for discussion, on his side sometimes of a rather choleric nature.

One day he said to me in a temper, "If you think so much of Bismarck and Germany in general, why don't you sit down and write a book on the subject? But that you will never do. You have not got the grit to begin a task and to finish it, which, let me tell you, is a very different thing from talking glibly about it."

In the summer of 1888 I took advantage of a holiday in the Black Forest to write a series of essays based upon my desultory knowledge of Germany, to which when published in book form, I gave the rather ambitious title of Imperial Germany. The book met with a success I could not have anticipated, and was shortly afterwards translated into German and French. 
Some personal friends of the Bismarck family, resident in London, with whom I happened to be acquainted, suggested that I should send the Prince a copy of my book. I did so, and in return received an invitation from Count Herbert Bismarck to come and pay his father a visit. This I lost no time in doing. My first visit ended with an invitation to come again; my second brought the expression of a hope that I should not return to Germany without knocking at the Schloss door of Friedrichsruh. In short, between the years I 89 I-6 I was the guest of Prince Bismarck on no less than ten different occasions. On the 3oth July, I 898, I again started for Friedrichsruh, in the hope of seeing him once more, but was destined, alas! to find on my arrival that he had passed away during the preceding night. A year afterwards I made a pilgrimage to his grave. 


\section{CHAPTER II}

\section{FIRST VISIT TO PRINCE BISMARCK}

APRIL, I89I

$\int \begin{gathered}\mathrm{HE} \text { express trains running between Berlin and } \\ \text { Hamburg are among the fastest in Europe, }\end{gathered}$ and do not stop at Friedrichsruh. But as long as Prince Bismarck lived they drew up at that little country station whenever anybody was travelling on a visit to the Prince. This privilege, however, was only accorded to a visitor who came at the Prince's express invitation, and was in a position to prove as much to the satisfaction of the stationmaster at the starting-point.

When the train approached the Saxon Forest and began to slow down many inquisitive heads were craned out of the windows to see who it might be that was privileged to visit the great German Hermit, and thus for a short moment to become himself a notability to be envied.

On alighting at Friedrichsruh I noticed a carriage and pair drawn up outside the station. One of the Prince's servants was on the platform evidently on the look-out for a visitor. $\mathrm{He}$ came 
IO FIRST VISI'T TO PRINCE BISMARCK

up to me, and I had hardly handed him my bag and turned my steps towards the carriage, when I saw two tall, imposing-looking men dressed in black coming along the road towards the station, who proved to be Prince Bismarck and his son Count Herbert. They bade me a warm welcome in perfect English. The Prince's carriage drove past us freighted with the "belongings" of an obscure citizen of the world, whilst Bismarck led the way on foot towards the Schloss, which is situated only about two or three minutes from the station along the carriage road.

The Prince wore the familiar black felt hat and a double-breasted black frock coat. He certainly looked more robust than eleven years before, when I had last seen him, on the way to Kissingen, alighting from a railway carriage, stooping as he walked with the support of a stick. His complexion in particular had a rosy freshness. An elderly military-looking man, whose erect gait might well have vouched for many years passed in active service, was walking by my side, apparently in the best of health and spirits. I was surprised at the great difference between the impression Prince Bismarck made upon me and what I had been led to expect from the mendacious reports circulated at the time concerning him.

As we entered the grounds and stood facing the Schloss, I gleaned from a chance word that it was the Prince's usual hour for a morning stroll. $\mathrm{He}$ asked me whether I would like to accompany 


\section{A WALK WITH BISMARCK}

him even before going indoors to take possession of my quarters. I was only too glad to do so, while Count Herbert disappeared within the house.

Prince Bismarck led the way by a narrow path, skirted on one side by a running brook. We were soon out of sight of the Schloss, sauntering in the peaceful solitude of his woody domain. The birds were chirping merrily overhead, a kind of music which was one of Bismarck's delights. As we were walking along the Prince said that he had read my book on Germany with interest, and wondered where I had got my knowledge from. I told him I had been educated in Germany and that national character had long been my favourite study. Bismarck alluded to one chapter in particular, which he said showed a special knowledge of the envious, ill-natured side of the German character; so much so, he humorously added, as to give him the impression that the author must have lived in his own immediate vicinity, and been witness of all the envy and uncharitableness which were to be found rampant among his neighbours. They could not forgive him for having " got on" in life, and, worst of all, for having become, what they considered him to be, "a rich man."

Our walk brought us to a meadow intersected by a stream, on which a swan was watching the movements of a foal feeding close by. The Prince drew my attention to this, remarking that the swan was evidently jealous. 
"Do you see," he said, "how that bird draws itself up? It knows that we are watching it, and wants to show itself off to the best advantageGearly a female. Animals have a language of their own, you know; it is only the conceit of man that bids him fancy he has the monopoly of speech."

Prince Bismarck seemed particularly anxious to show me his tree plantations. They were full of all sorts of firs in all stages of growth, and apparently from all parts of the world. The Levant, Japan, North and South America, he had laid all of them under contribution and had collected an assortment together of over thirty varieties, some of which he cited by the Linnæan designation. I learnt subsequently that a gentleman of English extraction, who owns large tree plantations near by, had assisted the Prince in the gratification of this taste for fir trees. It was a revelation to find in one whose whole life had been devoted to the exciting struggles of men, this rare power of concentration directed towards the slow, peaceful products of nature. I could understand that he should care little for artistic gardening. Carefully laid out plots of turf would not be at all to his taste. He would prefer broad woodland landscape, what the Germans call "Der Hain," the grove, the natural grouping of the glade, which, with its depth and shading, the free and wild development of nature, leaves scope to the imagination. I gleaned, indeed, from his conversation that to the Prince 
trees possessed more than the common interest of inanimate things. He loved to watch their growth, and when they attained maturity he was loth to have them cut down. His rich imagination endowed them with a life he was unwilling to shorten.

We now came upon a bench ensconced in the shady corner of a meadow backed by thick bushes and sat down.

"This used to be one of my favourite seats," he said, "but a stupid gardener of mine has planted these young shoots in front of it-they will soon spoil the view; but I shall have them taken out and placed elsewhere."

In our further wanderings we passed a lake, on the opposite shore of which a target was visible.

"It is the only place in which I can keep up my pistol practice without fear of accidents," he said.

I remarked that it seemed a long range for a pistol. It must have been over a hundred yards.

"Oh, my revolver carries that distance easily. And though I am not so young as I used to be, my hand is still fairly steady. I can now and then manage to bring down a squirrel.'

By this time we had come back to the house, and Prince Bismarck accompanied me to my room on the first floor. It was a large apartment with the bed divided by a screen from the rest of the room -thus sitting-room and bedroom in one, with two large windows giving a charming view of the park. On coming down into the drawing-room I was 


\section{I4 FIRST VISIT TO PRINCE BISMARCK}

presented to Princess Bismarck and her daughter Marie, Countess Rantzau, whose husband was absent at the Hague, where at that time he filled the post of German Ambassador. Princess Bismarck's face wore a sad expression, as of one suffering from ill-health; this was all the more noticeable when her features momentarily lit up with a ray of kindly interest for what was going on around her. She was already at that time sorely tried with asthma, the complaint which so painfully affected her during the last years of her life.

Everybody rose as Prince Bismarck came into the room accompanied by his secretary, Dr. Chrysander, and we immediately passed into the dining-room for luncheon. It was about thirty feet long by about eighteen wide, a room in which thirty to forty people could have comfortably found place at table. The walls were painted a plain grey colour with no other ornaments than a couple of landscapes in oil, which hung in black and gold frames on either side of two oak sideboards, on which stood a number of old silver centre-pieces, tankards, mugs, and beakers. Three large windows afforded an extensive view of the park. Looking out of the window one could easily imagine oneself in further Pomerania, such was the seclusion of an extensive woodland scenery; and this lent a peculiar airy character to the room.

Prince Bismarck took his seat at the head of an oblong table. I was placed by his side. Both he and the Princess evinced a keen interest for what 
was going on in the outside world, and as I had brought kindly messages from their friends in London, there was at once a subject to start conversation, in which Princess Bismarck, notwithstanding her bad state of health, took a lively part. With a sly touch of humour she said she hoped I liked my room, for it was the one the Emperor had occupied when he had been at Friedrichsruh. It was a family meal in the patriarchal sense. No family gathering could have been less conventional and, consequently, more genial. The cuisine was evidently a great feature, and I noticed how a new idea of the chef met with general recognition. The Bismarcks-both father and son-were keen judges of wines; though since Dr. Schweninger had somewhat restricted the Prince's diet the choice of the wines devolved upon Count Herbert.

Towards the end of lunch letters and newspapers, which had just arrived, were brought in, and also Prince Bismarck's long pipe, cigars being handed round to the rest of the company. A tray with a tobacco-jar and a variety of peculiar rods and knives was also placed upon the table, and the Prince proceeded to use them with a view of securing a good draught through his pipe.

After lunch Prince Bismarck invited me to take a drive with him, whilst the other guests, led by Count Herbert, followed us some distance on horseback. On passing through the gate of the Schloss a loud cheer greeted us from the crowd of people standing bareheaded in the road: "Long life to 


\section{I6 FIRST VISIT TO PRINCE BISMARCK}

His Serene Highness Prince Bismarck, the Unifier of Germany."

Once in the Forest, the carriage left the high road and threaded its way through the lofty beeches and firs regardless of any path. The Prince was anxious that I should get a sight of as many deer and wild boar as possible, to effect which we drove round, so as to advance with the wind in our favour. We only saw the deer scamper off in the distance, but we got a closer view of some magnificent wild boar, a whole herd of which leisurely crossed our path within a few yards of the horses.

We had now got far from the road, amid the tangled underwood in front of a shallow brook which impeded our progress. The coachman was obliged to dismount in order to find the way back to the main road. Bismarck pointed to two stately pine trees in front of us.

"There, up in mid-air, between those trees, I should like to find rest, where the sunlight and fresh air can still get at me. The idea of being shut down, suffocated in a 'band-box,' has its terrors." The Maoris, he had probably heard, hoist their dead chieftains up between the boughs of two tall firs in the solitude of the forest, and leave them there to the buffets of the wind and weather.

We regained the open, and several large farmyards were close at had. The Prince discussed his system of farming the land. He spoke in 
English, and, to my surprise, was thoroughly acquainted with many of our technical agricultural terms. He wanted to show me one of the typical old Saxon farmhouses-low, brick buildings, in which the owners shared the ground floor with their cattle. Their chief peculiarity is the absence of any chimney, the smoke from the hearth finding egress above the door.

We alighted and entered. The peasant and his wife came forward to welcome us and kiss the Prince's hand. We sat down in their little sittingroom at the back, which was scrupulously clean, for the cattle were herded in separate pens on each side of the entrance. Coloured prints of the Emperor, Moltke, and of Bismarck were on the walls. The Prince was evidently a kind landlord, to judge by the brightness and a visible affection with which the old couple greeted him. He asked their age, whilst the woman seemed instinctively to retain her hold upon his coat.

"Ach, Lieber Fürst, I was eighty last birthday and my husband is eighty-two."

"Oh, surely that is not so bad; why, you see, we are not far apart. We have both life before us yet."

When we reached home it was nearly six o'clock and close upon the dinner-hour, which in the Bismarck family was an unusually early one for West European ideas. The guests, as well as the ladies of the family, were soon assembled in the drawingroom-among the former a very pretty woman, 
Baroness von Merck, a neighbour, and, as I subsequently learnt, a great friend of the family. Nobody was expected to "dress" for dinner. The ladies did not wear low dresses, and the conventional "swallow tails" were tabooed. The double-breasted, black frock-coat was de rigueur, except on one solitary occasion in the yearBismarck's birthday, when full evening dress was worn.

The conversation at table turned upon Bismarck's old friend Motley, of whom he spoke with a tenderness which would have surprised those who only knew the iron statesman.

"Yes, Motley's was a singularly ideal and lofty character," he said.

"But was he not of rather delicate physique?" I ventured to ask, struck by the contrast between the giant at my side and my own impression of Motley's stature.

"Oh no, scarcely delicate; but his was a sensitively nervous organisation. A few glasses of wine soon made him lively. And then he would lean back in his chair and, with his hands under his coat behind his back, he would recall his favourite song of the student days we spent together at Göttingen :-

" 'In good old colony times,

When we lived under a king,

Three roguish chaps

Fell into mishaps

Because they could not sing," "etc. 
I expressed my surprise that $H$ is Highness should have remembered these lines-in a foreign language too-all these years. I addressed myself specially to Countess Rantzau, who had joined her father with great zest in repeating "In good old colony times," as well as a second couplet belonging to the same curious ditty.

"Oh," she said, "my father remembers many more English rhymes which he learnt from his English and American fellow-students at Göttingen. For instance," and the Countess recited the following, Prince Bismarck joining in to assist her at every halt she made :-

" 'God made bees, bees made honey;

God made men, men made money;

God made Satan, Satan made sin;

God made a little hole to put Satan in.

" 'Satan said he wouldn't go ;

God said he should;

Satan said, If I go

D-n my blood!'”

Both Prince Bismarck and his daughter seemed to derive satisfaction in conjuring up the dreadful plight of Satan. It was quite comical to watch his face as he repeated the lines, his eyes twinkling with fun. These nursery rhymes evidently appealed to his keen sense of humour.*

* Some years later I had another opportunity of testing Bisnarck's appreciation of English humour in the form of nursery rhymes. The Minister of a great Power had just made a speech containing a somewhat provocative reference to another great Power. Bismarck on reading it exclaimed in English: "Whoever dares these boots displace must meet Bombastes face to face." 
20 FIRST VISIT TO PRINCE BISMARCK

Recalling Motley's lively spirits under the influence of a glass of wine, I remarked that it was a strange fact that the population of wine-growing countries were usually moderate drinkers.

"Yes," Bismarck said, "this is indeed a wonderful dispensation of Providence. For where wines grow the people are usually 'half-seas over' by nature; and if they were given to drink as well, they would soon be perfectly mad."

Asked how he accounted for this, he replied that he concluded that the power of the sun must be partly accountable for it. To this I added that there was plenty of sunshine in Palestine, and that I wondered whether the Jews, who were ever reputed a cool-headed race, grew vines.

"Yes, to be sure," replied Bismarck, "wine and olive oil were their staple trades. And they must have been stout drinkers too at times. Don't you remember the marriage at Cana of Galilee? We are told they drank hard on that occasion, or at least led to infer as much from the remark that the good wine was first consumed, and the inferior reserved until the company had lost all sense of discrimination."

Towards the end of dinner, Bismarck turned to give a bone to his dogs, who were his constant companions, when somebody mentioned the wellknown incident during the Berlin episode of Prince Gortschakoff's rencontre with Tyras.

"That affair," said Bismarck, "has been totally misrepresented. Gortschakoff was sitting in con- 
versation with me, when, in rising from his chair, he seemed to stumble, and I sprang towards him fearing he might fall. Tyras evidently imagining that we were wrestling, made a bound towards us from the other side of the room. I called to the dog in a loud voice, but Gortschakoff, possibly surprised at the tone of my voice (my mouth was close to his ear), ejaculated: 'J'étais venu dans les meilleures intentions.' I fancy it must have been some sudden fit of faintness on his part, and that it was my voice, and not the $\operatorname{dog}$ at all, that startled him."

Dinner over, the company moved to the drawingroom, the latest guest leading Princess Bismarck. There, according to homely German custom, the children kissed their parents, and Prince Bismarck bent down and kissed his wife's forehead. A wave of warm sentiment rolled in upon me as I watched this stately figure-a benevolent smile on his lips and the glow of kindliness in his eyes. There was, indeed, something majestic in his repose, and yet with all one saw the homely father, the devoted husband as well. I could understand how it was that round this man there should circle a devotion which was more than love, for it included reverence.

I glanced round the room, and my attention was attracted by two pictures on the wall. They were family groups of father, mother, and children in the dress of the Reformation. They were ancestors of Prince Bismarck, and they reminded me of a picture of Dr. Martin Luther and his 
wife Katherine von Bora and their children. The man, perhaps, least of all, for he wore a beard; but the boys-evidently young Bismarcks of the period-had something of the redoubtable Saxon monk's broad features and all the pugnacity we associate with his name.

The newspapers were now brought in-an endless collection. Not that Prince Bismarck subscribed to many; they were sent to him from far and wide by known and unknown hands. $\mathrm{He}$ sat in his easy-chair, and I lighted his long china pipe, which he had smoked after lunch. The family and visitors sat or stood in groups around.

The Geestemünde election, for which the Prince had just been put forward as a candidate, was about to take place, and a French paper-L'Autoritehad a leading article entitled "The End of the Ogre," written, if I remember rightly, by Paul de Cassagnac. Bismarck read a short passage of it aloud, puffing at his pipe between the sentences. The grossness of the abuse evidently amused him exceedingly-the "cruel mouth," the "wicked eyes," the "fierce, bushy eyebrows," and he remarked facetiously, "It is really wonderful how they will hang on to my poor eyebrows."

I had brought a printed cartoon, a parody of the well-known old German woodcut, "Der Löwe Kommt," which humorously illustrates the effect of the breaking loose of a lion during a country fair. It was entitled "Bismarck is Coming," and represented 
the Chancellor entering the Reichstag during a debate upon the Commercial Treaty with Austria. $\mathrm{He}$ is portrayed as an old gamekeeper, smoking his pipe, and the effect of his coming on the members is similar to that produced by the appearance of the lion. His dog Tyras is already at the tribune "dealing with" the "nether garments" of Bismarck's special aversion, Eugen Richter, the well-known Radical Parliamentarian. Many members of the Reichstag are flying in all directions, whilst others rally round Bismarck. "Ah, that is all very fine," he said, peering over the cartoon as it was spread out on the table before him, "but if I went there I should stand quite alone."

Somebody made a remark not very complimentary to Bismarck's enemies, to which he replied in a playful tone-

"Believe me, there is nothing some of my enemies find so difficult to forgive me as the crime of having become a rich man. Well, I suppose I must admit that I have been fairly successful in a material sense; I even wonder at it myself sometimes. For when I look back it seems to me that my wants were not extravagant. So long as I have a chair, and a table, and something overhead to keep the rain off, I am sure I could be happy."

And in saying this he turned his face upwards and made a gesture-simulating an attitude of seeking protection from a threatened rainfall. 
24 FIRST VISIT TO PRINCE BISMARCK

Bismarck had been cruelly slandered by his foes, and there was an element of tragic pathos in the situation; yet it would have taken a bold man to offer condolence to one who, in his day, had so often smitten his enemies hip and thigh. At least, it is certain that nobody big enough to dare to pity him ever came to Friedrichsruh. The old Emperor William - the only one whose sympathy would have appealed to him-lay in his grave. Kind as was the expression of Bismarck's face when he was comfortably seated at his own fireside, there were yet moments when his large, expressive eyes lit up with a threatening gleam. It was like sheet lightning shot across a landscape of a summer's eve, just sufficient to remind us amidst an idyll that there are forces ever latent in men as in nature that need only to be called into play to terrify us.

To an inquiry what his course of action would be in case he should be elected for Geestemünde, he replied that it was his present intention to appear in the Reichstag only if a question of exceptional importance should come up for discussion, in connection with which he might deem it his duty to give the country the benefit of his experience. Regular attendance on his part was out of the question. The thought of being obliged to stay even for one night in Berlin, or to take lodgings there, was obnoxious. "I find it difficult enough to sleep sufficiently in my own house, let alone in a strange place," he said. Prince 
Bismarck never saw the Reichstag again, although he was elected one of its members within a few days of the above conversation.

Among other subjects touched upon was a statement in the Paris Press, and thence copied into newspapers of various countries, that Prince Napoleon had recently had an interview with Prince Bismarck at Friedrichsruh. Bismarck dismissed it with a derisive smile and a shrug of the shoulders. The recent attempts in the French as well as in some English papers to emphasise the pernicious effects resulting to Italy from the Triple Alliance, were mentioned. Prince Bismarck said that alliances, like other human arrangements, were subject to the influence of time and circumstances; but that the Triple Alliance was a natural one, a political necessity to Italy, although the armaments were perhaps greater than she really had need of, and might with safety be reduced.

It was in connection with the above topic that on my return to Berlin I was told the following story by a Privy Councillor, who had formerly been very intimate with Prince Bismarck.

Some years ago an article in an English review caused a stir by its insistence upon the idea that England's true policy would be to hold herself aloof from Continental politics, and that Italy would be well advised to retire from the Triple Alliance. The article was signed simply by the letter "G."; but it was generally attributed to Mr. Gladstone. Bismarck was reading it one day, 
when, looking up to a visitor (the Privy Councillor in question), he asked him whether the article did not recall any passage of Shakespeare to his memory? His visitor, although thoroughly familiar with Shakespeare, racked his brain in vain to find an analogy.

"But surely just think," said Bismarck, "don't you remember Richard the Third? Think of those words, 'England, beware of Gloucester.'"

In further conversation on the present occasion the name of Signor Crispi cropped up, and Bismarck spoke very highly of his political sagacity and trustworthiness. He further characterised the aims of the Triestine Irredentists as chimerical, and, even if realisable, as of questionable utility for Italy.

Thus the evening passed most pleasantly. At about half-past ten o'clock Bismarck rose to retire, and wished good-night all round. But his leaving was not in any way a signal for a general breakup. The company re-formed, and one or two fresh guests looked in, one of whom had arrived by the night train. He was a member of the South German branch of the family- "Graf von Bismarck, Major à la Suite des Isten Garde Dragoner Regiments Königin von Gross-Britannien und Irland." $\mathrm{He}$ was a most sympathetic representative of a class of people whose lot in life had been cast in pleasant places.

The Count had just come from Berlin, and in the course of conversation one or two instances 
were mentioned of the offensive behaviour of some obscure official personages towards members of the Bismarck family. Count August Bismarck related an incident in pleasant contrast-his own experience at a dinner he had recently attended at Count Schouvaloff's, the Russian Ambassador. Although one of the youngest guests present, he had been designated to go in first. On his hesitating to accept the place of honour at the table assigned to him, Count Schouvaloff had insisted with the words that anybody bearing the name of Bismarck would always have le pas in his house. Count Schouvaloff had also said that people were very much mistaken if they imagined that the fall of a minister must necessarily imply the eclipse of a great name.

Refreshments were now brought in. Count Herbert Bismarck looked after the wants of the company, and soon conversation on current topics became general. But for one like myself, to whom a day spent in intercourse with the master mind of his age was an event in a lifetime, it was not easy to take a share in it. The more lively it became, the more my imagination seemed to seek refuge amid the thousand and one memories of Prince Bismarck's extraordinary career, which took new and warmer colour from my recent intercourse with the man. It is more than a mere fanciful assertion that great men are invariably endowed with the power, figuratively speaking, of magnetising or hypnotising those who are brought into personal 
28 FIRST VISIT TO PRINCE BISMARCK

contact with them, and this dæmonic gift has rarely been possessed in a greater degree than by Prince , Bismarck.

My first day at Friedrichsruh had been a full one, and I retired to my room whilst conviviality was still at its height. 


\section{CHAPTER III}

\section{FIRST VISIT TO FRIEDRICHSRUH}

(CONTINUED)

T $\mathrm{T}$ was evident that the Bismarck family were in 1 the habit of remaining up late; I was therefore not surprised next morning to find that they were not early-risers. So after partaking of an excellent breakfast in my room I started on a little exploring expedition through the house, out into the grounds, and through the village.

The Schloss was originally built for a country "Luftkurort"-something like our English hydropathic establishments. The plan of the building is still more or less in accordance with such a purpose; although since the property came into Prince Bismarck's possession many alterations and additions have been made. The first floor consists of a number of visitors' rooms, the only small one of which was occupied by Count Herbert. The others are large and lofty. They were plainly, but cosily furnished. Photographs of eminent persons who had been on friendly terms with Prince Bismarck hung there and here, without 
any attempt at arrangement, on the walls. Among them I noticed several American notabilities-one of General Grant, another of Mr. Phelps, at one time United States Ambassador at Berlin, an engraved portrait of Bancroft, the American historian, and another of Lord Beaconsfield. A reprint woodcut of Sir John Tenniel's famous cartoon, "Dropping the Pilot," was also in one of the rooms-not, as is often stated, the original drawing, which is in Lord Rosebery's house in London. Everything bore a comfortable homely stamp, even down to the old white and blue Dresden moderator lamps which were lit every evening, and cast their soft light on a writing-table upon which pens and papers were regularly placed for the convenience of the guests.

There were two staircases of a somewhat labyrinthian character at opposite wings of the house: the one by which I descended necessitated my traversing several rooms on the ground floor in order to reach the front door. Not a soul was to be seen-except a servant or two as I came down. In passing one of the rooms on the ground floor an oil painting caught my eye, which I had not noticed the day before. It was a portrait of Prince Bismarck, apparently taken in the "Fifties" during his residence in Frankfort. He wore a black dress-coat with the insignia of the order of St. John hanging from the neck and affixed to the coat. A peculiar Cagliostro-like expression gleamed from the eyes. I thought they looked at me sus- 
piciously, as much as to ask, "What dost thou here at such an hour?"

The artist had evidently been quite incapable of seizing the intellectual cast of Bismarck's features. He had given them a sly, foxy look. This, however, may well have been about the intellectual level the artist would look for, and probably have found, in a regular attendant at the soul-killing Frankfort Diet of somnolent memory. The art of portraiture in those days was as much in need of a rejuvenating Lenbach as politics of a Bismarck.

I took a glance round the rooms and was struck by the lack of arrangement in the furniture. A certain Bohemian, though by no means uncongenial, disorder prevailed. It was, however, as far removed from untidiness as it was from that painful precision which inspired Bismarck with one of his smart sayings. This was to the effect that when you find too much care bestowed upon the furniture of a house, the chances are that you will discover the cooking to be inferior.* The converse certainly held good in the Bismarck family, for the cooking was indeed excellent.

Some visitors to Friedrichsruh have affected astonishment at the unpretentious simplicity of the house, which, they say, did not convey to them the idea of what the Germans call a Schloss, or

* The pyschological truth underlying this observation of Bismarck is strikingly illustrated in one of Victor Cherbuliez's novels, Olivier Maugant. 
we English a castle. And to a certain extent this surprise is justified, though such comments are more interesting as revealing the frame of mind of the observer than from their bearing upon the subject. It is customary to call the building a Schloss, and for brevity's sake this may pass. But in reality the residence of Friedrichsruh, as of many a German noble family, is what we term a manor-house-be it big as a barn or small as an attic, in the form of a square, a parallelogram, or triangle-in short, the house of the lord of the manor-his mansion-and that lord was Prince Bismarck. The Germans do not possess the exact term, for which the only rendering would be "Das Herren Haus." As such, however, no building could have been better suited to Prince Bismarck. The house itself, let alone the princely estate, possessed the one sine qua non condition of distinction - the dignity of space. With the extensive view from the dining-room the possessor could indulge at will in the sense of the unlimited nature of his property, a feeling those can best appreciate who have lived much in broad scenery, far from the busy crowd of town life.

In curious contrast to the extent of the estate one side of the Schloss abutted upon the high road in direct touch with all the publicity of railroad and village life. This contiguity with the outer world was congenial to Bismarck, even though at times it had its inconveniences. Throughout the greater part of his life his official position had made it 
difficult for him to walk unobserved in town or country. He was able to do this more or less in Friedrichsruh, and he liked to mingle with the country folk round about him. $\mathrm{He}$ also enjoyed the contrast between the solitude of the wood and the bustle of the road. Had this been otherwise, he would never have decided that his last restingplace should be near a railway station, a vicinity which people of his caste and position usually affect to dislike. Perhaps the fact that the dignity and affluence of the family were not painfully contrasted by the dirt and poverty of humble villagers, as is often the case of noblemen's estates in some countries-notably, but not only in Bohemiathis possibly had something to do with Bismarck's liking for the village. Friedrichsruh is a favourable specimen of a German village; it reflects a high civilisation. I never once saw a pauper, a beggar, or a shabbily dressed person during all my visits to Friedrichsruh.

In the course of the morning Count Herbert asked me whether I would like to ride out with him and his cousin Count August Bismarck, and before long we were all three in the midst of the Saxon Forest careering at a gallop over "Stock und Stein." Count August Bismarck was something of a steeple-chase rider, and such a ride in his company was a thing to look back upon thankfully when once over and uninjured bones allow of our doing so.

On our return we met Prince Bismarck in the D 
grounds, and I accompanied him for a stroll through the village. He took me to see the "Försterei," the dwelling of the head forester, Lange. Bismarck told me that he himself had lived there for some time, and had received visits from ambassadors whilst there, when he first came to Friedrichsruh and his present residence was being altered to his taste. His head forester was a fine-looking man, with a long, black beard plentifully streaked with grey. Prince Bismarck told me that he was a gay fellow, who was a great favourite with the fair sex in the village.

Every day a crowd collected about the gates to catch a glimpse of the Prince as he left the Schloss for his afternoon drive. People came from all parts, and especially on holidays; Friedrichsruh even at that time had become a shrine for pilgrims. Sometimes they vented their feelings in loud cheers; at others they uncovered in silent reverence. This was only one of the many indications of the Prince's hold upon the heart and imagination of a vast section of the German people that I noticed during my first visit to Friedrichsruh. Whereas the foreign Press, and, more particularly, a part of the German Press, endeavoured to make the world believe that the sentiments of his countrymen towards him were of a totally different nature. Scarcely a day passed but telegrams arrived embodying good wishes and expressions of devotion from some social gathering throughout the country. When the train stopped at Fried- 
richsruh every head was put out of the carriage windows in the hope of catching a glimpse of the "retired" statesman. And should he happen to be on the platform to welcome a friend or bid adieu to a visitor, a forest of hats waved in deferential greeting.

One of the sincerest tributes of those days came from Bavaria, in the somewhat cumbersome shape of barrels of Bavarian beer. There was no end to them, sent by Bavarian brewers in the hope of receiving an autograph-letter in acknowledgment, expressing appreciation of the excellence of the brew. For whereas Prince Bismarck's closer countrymen had quietly acquiesced in him being put on the list of the "played out" ("Auf dem Aussterbe Etat") as one whose opinions were of no further consequence, the shrewd Bavarians had still the most implicit faith in his judgment on a matter of far more importance to them than politics or even religion-the quality of their beer.

The interior of the Schloss itself, however, supplied perhaps the most tangible proof of the place Prince Bismarck held in the hearts of his countrymen. The rooms were full of presents sent to him, and I was told that it was the same at Varzin and Schoenhausen, his other seats. Among them was a number of books dealing with his career, portraits, busts, illuminated addresses, presentation pieces of furniture sent to the Prince by Trades Guilds or other corporations and societies. A large oak chest stood against the wall of the morning-room. It 
was the gift of a paper manufacturer, and contained enough writing materials for generations to come. I also noticed an imposing oak chime clock, which might well sound the hours of joy and sadness in the family for many a year yet.

Two mammoth iron safes contained the recent presentation of the German manufacturers. It consisted of a silver dinner-service, said to represent a money value of about a quarter of a million marks. Whilst we were inspecting this, a servant brought two sets of massive gold drinking cups, gifts from the German residents of Moscow and Odessa.

I was rather struck by the small amount of attention bestowed upon these costly offerings. Princess Bismarck, for instance, seemed to think more of a telegram from an obscure but kindly well-wisher than of any of these tributes in gold or silver. As for the Prince, I do not think that he ever saw half the presents that were sent to him. He certainly never referred to them. Even Lenbach's beautiful portraits of him - two of which hung upon the walls, and called forth the admiration of every visitor-seemed hardly to exist for him.

On one occasion I mentioned this fact to Count Herbert Bismarck, and added that I felt his father was extremely indifferent towards the decorative side of life; that of all things decorations would be the least likely to possess much value in his eyes; that there were only two such which I could fancy him prizing. These were the medal for 
saving human life, "Die Rettungs-Medaille," aná the Prussian Order "Pour le Mérite."

"It is strange," he replied, "that you should mention this, for they were indeed the first and last distinctions conferred upon my father."

There were exceptions, however, to the Prince's indifference towards the offerings of his admirers. Among the treasures of Friedrichsruh I was shown a silver tankard - a so-called thalerbeaker - in which a number of old and new German coins were let in. It was a present from a publisher of Oldenburg of the name of Schwartz, who was also the proprietor of a periodical entitled the Volksboten. Bismarck was much impressed by this man's patriotic sentiments, and was pleased with his gift. When later.on most of the presents were sent to Schoenhausen, he insisted on keeping this particular one by him at Friedrichsruh. He cared not for things, but valued the sentiments they were intended to convey.

About three weeks had elapsed since Prince Bismarck's birthday, but Princess Bismarck was still full of the gratifying marks of attachment he had received on that occasion-many of them from quite unexpected quarters. Never a word crossed his lips with regard to such matters either at the time or afterwards, but she had collected those messages which pleased her most and kept them in a portfolio. In the course of the second evening of my visit, she brought it in and read me several which had pleased her more particularly. They 
were not telegrams from the great of the world, although a goodly number of these had been received. The Princess took little heed of them; she thought more of quaint ideas in verse. She treasured these for the sentiments they conveyed, though some of the senders might be of humble position in life. Several of these she subsequently wrote out for me herself! They now lie before me in her handwriting. Among them are the following. From the poet Ernst von Wildenbruch :-

\section{Translation.}

"Thou goest from thy work,

But not thy work from thee;

For where thou art is Germany;

Thou wert: and thus were we.

All that through thee we grew

We know and every land;

What without thee we may become

We leave in God's own Hand."

Dr. Scheibler, Privy Councillor, professor in Berlin, probably risked official displeasure by sending Bismarck the following :-

\section{Translation.}

"Long may we thy presence hold, Growing older with the old, Yet thy power by age unwrung, Young for ever mid the young, Unforgotten by us, still

Ever unforgetable.

God's best gifts with thee be rife :

Love of work and joy of life." *

* These and the previous lines turned into English verse by Arthur Waugh. 
Carl Helmerding, the eminent Berlin comedian, long retired from the stage, was an especial favourite of the Bismarck family, and had sent a wittily-worded telegram to the Prince on the eve of his birthday.

The last contribution in the Princess's handwriting in my possession has no name of a sender; but the thought expressed especially endeared the lines to her. It was to the effect that the national yearning for Liberation and Unity, for which Theodor Körner, the patriot poet, laid down his life, had been at last realised by Bismarck.

I had come to Friedrichsruh among total strangers, but I had hardly been there thirty-six hours when I felt half inclined to believe that I must have been there in spirit on some former occasion. The kindly welcome had obliterated the shyness of coming for the first time among strangers, and, moreover, among such strongly accentuated natures as those which constituted the Bismarck family. For it was with no ordinary degree of curiosityI might almost say of trepidation-that I had looked forward to making the Prince's acquaintance. Hence it was with a certain amount of surprise that I found myself in the company of a country gentleman of the most charming manners imaginable, and of a kindly lady for whom the conventional formalities we expect to find in people of her station hardly existed. Had this been otherwise, it would have been impossible for a stranger, however kindly his welcome, to have felt himself at 
home in so short a time. That I had lived much in Germany and numbered among my acquaintance many well-known people whose names at least were familiar to the Bismarck family; that my literary efforts had betrayed a strong sympathy for Germany and her people-these may possibly have had something to do with speedily effacing the stranger in the eyes of my hosts; but whatever the cause it cannot detract from the pleasure of recalling the fact to memory.

It was the third morning of my stay, and I fain would have remained on another day or two. But I had enjoyed Prince Bismarck's company all to myself each day, both morning and afternoon. This, I felt, made it impossible for me to linger on without incurring the suspicion of indiscretion, although Princess Bismarck told me as a precedent of longer visits that an English painter, Mr. Xhad recently stayed a whole week in Friedrichsruh as a self-invited guest.

When I told Count Herbert that I was about to leave he said that he had got the copy of my book at Schoenhausen, which his father had read and wherein he had made a number of notes in pencil; that he would send it to me to London at an early opportunity, for he felt sure that I should like to keep it as a memento. This he subsequently did.

At lunch the visitors' book, which Princess Bismarck held in her keeping, was brought in, and I was asked to add my name to the list, which 
was headed by that of the German Emperor. This I did to the accompaniment of many kind words from Princess Bismarck urging me to come again soon and bring my wife with me. Prince Bismarck added that as I was only leaving between five and six in the afternoon there would still be ample time to take a last drive with him.

It was on this occasion that we met a man on the road who looked very ill. It was near a village, and he apparently belonged to it. Bismarck said to me, "Did you notice how ill that man looks? I wonder where he lives?" and the coachman was bidden to stop at several cottages to inquire: but no one knew of the sick man's whereabouts, and we in the meantime had lost sight of him. His looks seemed to worry the Prince far more than I should have expected. It struck me as a psychological mystery in the composition of one to whom the sight of suffering - of a perfect stranger too-might have been familiar enough to render him as callous thereto as an inhabitant of London.

It was getting late, and I looked at my watch, fearing our drive might make me miss my train. Bismarck turned to me and said facetiously, "You have got railway fever."

"Yes," I replied, "Prince, that is not the only malady we moderns are afflicted with which men of your stalwart generation did not know of."

Before leaving Friedrichsruh Prince Bismarck 
42 FIRST VISIT TO FRIEDRICHSRUH

was pleased to sign and date a portrait of himself for me. It thereby acquired a date of historical interest, for it was the 24th April, I89I, the very day on which Count Moltke passed away, as I learnt on my arrival at Berlin the same evening. 


\title{
CHAPTER IV
}

\section{VISIT TO SCHOENHAUSEN}

\author{
AUGUST, I89I
}

"Wär' nicht das Auge sonnenhaft,

Die Sonne könnt es nie erblicken." *-Goethe.

I $\mathrm{N}$ the following month I met Count Herbert Bismarck again in London, and on the 3 Ist August I paid a visit to Schoenhausen at his invitation. He had written to me that I should find the museum completed in which the presents his father had received during his career were exhibited. This museum is unique. It contains between two and three thousand different objects: gifts from kings, kaisers, and popes; testimonials from towns, corporations, and academies; the quaint offering of the artisan, as well as the modest handiwork of the widow. Most remarkable of their kind are several illuminated parchments : diplomas conferring the freedom of some city.

One executed by the renowned historical painter, A. von Menzel, is a gem. Nowhere else does such

* "Unless the eye be trained to light It ne'er could see the Sun." 
a rich variety of tributes to one man exist. But of greater interest than any imaginable collection of presents is the fact that Schoenhausen was Prince Bismarck's birthplace; that he chose the village of his birth to perpetuate his memory after death.

On the occasion of Bismarck's seventieth birthday the German nation collected a large sum of money by public subscription with which they bought back the estate which had once formed a part of the family property of Schoenhausen, and made him a present of it. A sum of $1,200,000$ marks beyond the amount required for that purpose remained in hand, and was placed at the Prince's free disposal to do with what he might deem fit. He decided to devote it to a fund to be named after his birthplace, and to be administered for all time to come from Schoenhausen. It was intended to provide assistance to deserving young Germans who had embraced the scholastic profession and might be in need of support prior to obtaining regular appointment; also to assist poor widows of German schoolmasters towards the education of their children. Thus has Prince Bismarck ensured his name being held permanently in honour by a hard-working and most deserving section of the community. But to the stranger the interest of this foundation is enhanced by the conditions under which it-in common with all similar dispositions in Prussia-is administered; they are indeed such as could hardly find a parallel 
outside the State of Frederick the Great. For instead of remaining an appanage of the Bismarck family, thus possibly latêr on becoming a source of favouritism, this trust is administered by Prussian law under the strict control of the State. The President of the House of Lords for the time being exercises supreme jurisdiction over its dispensation. Not even a Prince Bismarck, having once designated a sum of money for a purpose of public utility, is allowed in Prussia to influence its administration. He relinquishes all control over it. Hence, in perpetuating his memory in the village of his birth Prince Bismarck at the same time gave a striking illustration of the spirit of conscientious responsibility which underlies the administration of trust funds in the country he devoted his life to bring to glorious recognition.

There is a peculiar fascination about the birthplace of eminent men. If the greatest of composers could devote a Dead March to "La Morte d'un Eroë," there should be no reason why a Beethoven of the future might not dedicate a symphony to the Nascita d'un Genio, be he the enunciator of a moral idea or the political regenerator of his country. For music lends wings to the imagination and stimulates our sense of reverence, without which there is little to be done for good. We need not envy the man who stands unmoved at the startingpoint of a great life. It is natural to be impressed by that which is beyond to seek for-affinitybetween the surroundings of a great man's birth 
and his subsequent career. And there is justification for the belief that between them a connection exists.

Spinoza was born in a garret. From a garret he could gaze undisturbed at the stars, and become conscious that there is a divinity that "doth hedge them in." From a garret he could look down upon the crowd in the market-place and learn to despise its ideals and its pretensions. On the other hand, the spirit of Goethe could scarcely have risen amid such surroundings. His cradle stood in a home of ease and plenty. The first faces to meet his infant gaze were those of well-dressed men and pretty women. The Attic lyre is not an instrument to be strung to the groans of poverty, nor to the clank of marching hosts, nor yet in the cold blasts of northern latitudes. Goethe was born in the sunshine. The poet needs the sun. "I have drunk of the sun" ("J'ai bu du soleil") I once heard Alphonse Daudet say. And Frankfort-on-theMaine was a bright place when Goethe was born there on a summer's day exactly as the clock struck twelve, and Jupiter stood high in the heavens.

Very different the conditions of Bismarck's birth to that of the two men whose thoughts influenced him so much in life. He came forth from a dark background; for such, indeed, is furnished by the records of the village of Schoenhausen. Long centuries of strife and suffering had cast a shadow over the land. The old town of Tangermünde, the St. Stephen's spires of which are easily dis- 
cernible from Bismarck's ancestral home, was the scene of a fierce battle as far back as A.D. 983 . On this spot the Germans under the Margrave Dietrich of North Saxony, in league with the militant bishops of Magdeburg and of Halberstadt -the town from which after the lapse of a thousand years Bismarck's regiment of Cuirassiers took its name-broke the tide of Slavonic invasion. For centuries the tramp of armed hosts rarely ceased up and down the valley of the Elbe, from which Schoenhausen is scarcely two English miles away. During the Thirty Years' War Germany lost twothirds of her entire population. Whole townslet alone villages-vanished from the face of the blood-drenched earth. In many that remained no births or marriages were recorded for many years together. In Schoenhausen, for instance, only one peasant farm out of forty-six escaped annihilation. The church register of the neighbouring village of Fischbeck significantly states that in the year I645 no burials took place. The dead were thrown to the dogs or left to the carrion crows. Driven by the pangs of hunger, men fed on the bodies of their kin.

Schoenhausen was burnt to the ground. Even the foundations of many buildings were wrenched from their bed. An oven of ornamental Dutch tiles of the sixteenth century was recently dug out of the earth nine feet deep, presumably on the site of some house of which all traces have disappeared. The village, as it exists to-day, is laid out on an 
entirely different plan. The church and Schloss alone, though repeatedly pillaged and burnt, stand where they did. Half a century after the Thirty Years' War huge mounds of burnt ashes still lay many feet thick, untouched, in the farmyard ad. joining the Schloss.

Dark days again broke over Schoenhausen with the advent of Napoleon the First. Only nine years before Bismarck was born the village was plundered by the French. His parents had to fly for shelter to a wood hard by, where they passed the night. The neighbouring town of Tangermünde witnessed a scene of pathetic sorrow. Here Queen Louise of Prussia received the fatal news of the Battle of Jena:

"Here did she fall a tear, here, in this place I'll set a bank of rue sour herb of grace. Rue, even for ruth, here shortly shall be seen In the remembrance of a weeping queen."*

Seven years later a thrilling ceremony took place in the church of Schoenhausen. It was the benediction of the reconstituted Free Corps of Major von Lützow, which was composed of men who had come from all parts of Germany to fight for the emancipation of the country from the Napoleonic yoke. Conspicuous among them was young Theodor Körner, the poet, who by his patriotic songs proved to be the herald of German liberation. In looking through the church register

* Shakespeare, Richard II. 
he came across the following entry made by the village pastor shortly after the Battle of Jena :-

"Since the Thirty Years' War no enemy's foot has trodden this peaceful nook of the Elbe and the Havel. God protect our dwellings, our farmyards, and our cattle. Otherwise our plight will be pitiful. Oh, golden peace, blessed tranquillity which was ours, when will you return?"

In a vein of prophetic inspiration Körner wrote underneath :-

"Then when Prussia's noble warriors, fighting with God for King and Fatherland, shall enter Paris.

"TH. KÖRNER."

The Bismarcks of old must needs have been a truculent and pugnacious race. In this, however, they resembled the rest of the small Prussian nobility, concerning whom we learn from Johannes Scherr, Gustav Freytag, and other authorities, that fighting, gambling, and living in the fear of God were their alternate cares.

According to the register of the church, where many Bismarcks lie buried beneath the flagstones, there was hardly a country in Europe in which at some time a representative of the family did not do battle. A full record of fighting stands to their account during the seventeenth and eighteenth centuries-in Holland, in France, on the Rhine, in Hungary, and even far away down in Southern Russia. Strange to say, a Bismarck was serving under Bernhard von Weimar in alliance with the French in the very campaign 
which resulted in Alsace being torn away from Germany. At the Battle of Fehrbellin, under the Great Elector, a Bismarck was deputed to bring the captured Swedish standards to Berlin. Another of too choleric a temper killed his servant in a fit of passion and had to leave the country. He did his fighting in the Russian service, underwent a term of banishment in Siberia, and died at Pultawa, I750. Later on another scion of the family served with an Anglo-Hanoverian contingent, and got into trouble owing to his duelling propensities. He afterwards entered the Wurtemberg service, became a great admirer of the first Napoleon, and stood on the French side on many a hard-contested field. Two Bismarcks were officers in Major Schill's Free Corps, which still fought on against Napoleon after the peace of Tilsit. Eleven of Schill's officers were shot at Wesel by the French in 1809 . Finally seven scions of the Bismarck family took part in 1813 in the War of Liberation. Three of them were killed, the remaining four returned home with the prized decoration of the Iron Cross. Thirteen inhabitants of the Schoenhausen lost their lives in that same fateful struggle. Their memory is still honoured in the village church, where the blood-stained standard is deposited which they followed to the watchword_-_ Mit Gott Für König und Vaterland."

Schoenhausen was then, as in the present day, a village of about two thousand inhabitants, noted 
for its breed of horses, one of which, a Prussian prince, brother of the King, rode right through the campaign against Napoleon of $181_{3}-14$, as he himself once told Bismarck.

A huge boarhound came scampering towards us as, leaving a large farmyard on the left, we drove up in the shade of some enormous chestnut trees to the front door of the Schloss. It is a plain, grey-stone building with stout walls similar to other country residences of the North German titled squirearchy; partly farmhouse, partly castle -belonging to a class which for many generations past have been half soldiers, half farmers. The Schloss is somewhat above the average of such in style and size. According to the date on the wall over the doorway, the house as it stands was built in the year I 700 , but the foundations date back many centuries. The coat-of-arms over the doorway is the only outside indication that it is a nobleman's seat, and not a nondescript private residence. The Bismarck crest consists of a threeleafed clover in conjunction with a three-leafed ilex, and often has the number three been cited as an important one in Bismarck's life. The capacious hall is ornamented by a number of quaint antlers affixed to the walls. The ground floor consists of a large dining-room, a drawing-roommorning-room-each with unusually fine stucco ornament ceiling. A broad oak staircase leads up to the first floor, on which is situated the room where Bismarck was born, and also the library 
in which his mother sought refuge from French soldiers. The door of the latter still bears the marks of French bayonets when they tried to force their way in. Nor is this the only memento French soldiers have left here. A large genealogical family tree is hung up on the landing leading up to the second floor. Many French bayonet thrusts are still visible through the painted canvas. The room in which Bismarck was born, when for the first time in the history of the family genius was allied to pugnacity, is unchanged since his mother was brought to bed there. A plain wooden bed stands at the further end of the room, partly hidden by some cheap chintz curtains which reach across the room. A couple of wooden chairs, a washingstand, a small round table, and a sofa, all of the simplest, and a plain polished deal floor without a carpet; such are the surroundings which here and elsewhere in Northern Prussia, by the disdain they inculcate for the emollient luxuries of life, afford some excuse for that pride of birth so often to be found hand in hand with them. A certain dignity-an air of veracity impresses the visitor who has seen many lands and peoples.

To those who take note of astrological fancies in connection with the exact hour of the birth of great men, it may appeal that Bismarck was born at one o'clock in the afternoon-not at that most auspicious hour of midday, like Goethe, but one hour later. The horoscope expert would probably tell us that this difference of one hour foretold the 
shadow cast over the last eight years of Bismarck's life.

The library is lined with bookcases and cupboards. Here young Bismarck, both before and after his marriage, often sat up alone till late in the night poring over the well-stocked bookshelves. This was the solitude in which, as Goethe tells us, "a talent shapes itself," before merging into the current of the world, in battling with which "a character is steeled."

A number of cannon, taken from the French and presented to Prince Bismarck by the old Emperor after the war of 1870 , are drawn up in the garden. Four of them stand in a row to the left of the Schloss. They are on a level gravel space, spick and span, set off by plots of beech hedgerowsforming a bastion by themselves. They give the impression of being on guard. They came from Strassburg, where they fell into the hands of the Germans after the siege of that city in 1870 . Two of them date back from before the French Revolution, possibly they had already belched forth their thunder in the days of the Roi Soleil. They bear the Bourbon lily in their casting, though some of these, with true French vandalism, have been erased with a chisel.

As in the case of many German country-seats, the grounds of the Schoenhausen Schloss show traces of the influence of French fashions in Germany during the seventeenth and eighteenth century. The avenues of trees, the hedges and paths which 
intersect each other at right angles remind one of Watteau-all the more so as sundry mythological statues in stone peep unexpectedly here and there out of stray corners. I also noted a glass pavilion $\grave{a}$ la Trianon of somewhat deserted mien. It is surrounded by a narrow moat filled with stagnant water. Here, in all probability, the Bismarcks of the period in powdered wigs took light refreshment on a summer afternoon. A statue of Hercules blackened by exposure, moss-grown at the base, may well date from the same period. At least it seems strangely out of harmony in the lime grove -the tree sacred to the old German gods. This is probably what young Bismarck thought when, as we are told, he peppered it with small shot. We can fancy him coming from school, eager for mischief like most high-spirited boys, running up against this Frenchified demigod in the garden: "What are you doing here in these northern glades?" and young Bismarck marked him with the shot still visible to-day.

Not far away in a quiet nook behind bushes is an iron railing enclosing a plain grave. It is that of a brother of Prince Bismarck's, who died when a little boy and lies buried here. An inscription tells the stranger that the only sorrow the little fellow ever caused his parents was his having to leave them.

Bismarck settled down at Schoenhausen after his marriage; but only for a brief period. The newly wedded couple arrived one autumn evening in 
1847. They came home from their honeymoon unannounced, for they wished to avoid a demonstrative reception on the part of the villagers. Only the old housekeeper of the family, Frau Bellin, was in the secret, and she, in her enthusiasm, had caused the Schloss to be brilliantly lighted up. As nothing was publicly known, the inhabitants of the neighbouring villages perceiving the unusual light from afar, thought the Schloss of Schoenhausen must be on fire. So they hurried to the scene with the full equipment of fire-pumps and ladders-a premature alarm of the big bonfire Bismarck was ultimately to make of the old order of things in Germany.

In the Revolution of 1848 Bismarck organised a militia drawn from among the inhabitants of Schoenhausen, Fischbeck, and Kabelitz. When those loyal villagers heard of the insurrection in Berlin they-unlike the inhabitants of the neighbouring town, who were more or less in sympathy with the insurgents-longed to take a part in the fray on the side of their King. One day, after several hundred of them, riding their own steeds and armed with rusty swords and match-lock carbines, had been through their drill with the obligato accompaniment of drums and trumpets, one of their leaders-a yeoman of the name of Schelling-rode up to Herr von Bismarck and said, "Now, Herr Deichhauptmann,* just lead us

* The valley of the Elbe near Schoenhausen is protected from inundation by an elaborate system of dykes, the supervision of which 
on, and we will soon put an end to all this Berlin nonsense!" A distinct note of pugnacity is here well befitting those who looked to a Bismarck for leadership.

The villagers are naturally fond of the man who has brought such renown to the name of Schoenhausen; but it is a pride, an affection, which is compatible with dignity and self-respect. It is the attachment of free men, not of helots. Thus when Bismarck last came here, although it was a day of rejoicing, they did not take the horses out of his carriage and harness themselves to the shafts. Nor would they ever expect the Prince to give them money to spend on beer to drink his health. They have served in the Prussian Army, and when they come back to the village they come back as men; not necessarily, or at all likely, to lean towards Socialism, but, at any rate, too much of men to accept doles or harness themselves to carriages like animals.

This attachment of the villagers has, I believe, now descended to the present lord of the manor, for when I came to Schoenhausen I saw the village children come up to Count Herbert to shake hands with him. I also noticed the pleased expression in the mothers' faces when they curtseyed to the Count. They smiled and looked

was vested in Herr von Bismarck in 1847 with the title of Captain of the Dykes. In the year 1845 the inundations of the Elbe had extended as far as Schoenhausen, and did a deal of damage to the park, destroying some of the venerable old lime trees. 
GERMAN STANDARD OF COMFORT 57 at him as if to say that they would liked him "to bring home a comely bride," which, for all I knew to the contrary, may already have been his intention.

A brewery is in the village and some beer gardens, where the villagers meet of an evening. Thither come the Herr Post Vorsteher, the Herr Eisenbahn Vorsteher, the village doctor, the apothecary, the mayor, and sundry others. They bring their wives with them on a Sunday afternoon and discuss the news of the day. There is no great affluence among them, for not much money circulates in agricultural Germany in these latter days. Still, everybody has a competence, however small, and is able to give his children a good education and to lead a self-respecting life. There is a high tone among these people, for they are well educated themselves, and have a feeling of their own worth and independence. Nobody lives on charity, and there are no drunkards, no paupers, no beggars in the village.

Altogether Schoenhausen is a favourable representative of those North German villages from which the flower of the Prussian Army is still drawn. It reflects a high state of rural civilisation. An air of comfort and cleanliness about the place has a soothing effect on the nerves of the jaded traveller.

There is an element of dignity even in the rigid, straight outline of the church tower, more like the turret of an old fortress than part of a 
place of worship. The church is quite a sight in itself with its black oak carvings, its many memories of bygone days. The villagers, I am told, don their best black clothes of a Sunday when they go to church. Though so near to Berlin, they are still happy in the simple faith of their forefathers.

The main street is very broad, as if it were intended to allow of an army marching comfortably through. A handsome monument in memory of those who fell in the wars of 1866 and 1870-7 I stands opposite the post office, which, as in many Prussian villages, is like the school-a more important building than their counterparts in many full-fledged towns in other countries. You breathe freely here, for there is an impression of ample space being devoted to useful, common objects for the welfare of the inhabitants. The dwellings of the humblest are scrupulously clean and of far larger dimensions than those of the same class either in rural France or England. Building land has not yet come to be parcelled out by the sweater in these regions. Nor did I see a single noticeboard in the course of my ramblings that "trespassers are to beware for fear of being prosecuted." The grounds of the Schloss and the adjacent woods are free to those who care to stroll of an afternoon under their shady trees-at least as far as any visible sign could tell to the contrary.

It was a beautiful summer's eve, and I had wandered away into the country when I was roused 
from my reverie. A familiar refrain struck my ear from a field in front-

" Drum Brueder stosst die Glaeser an, Es lebe der Reservemann

Der treu gedient hat seine Zeit

Ihm sei ein volles Glas geweiht." *

- A man in a military cap was tilling the soil; probably his own, for there are still peasant proprietors in the neighbourhood of Schoenhausen. He had served his time with the colours and now formed part of the Reserve, and will in due course be relegated to the Landwehr. $\mathrm{He}$ and his class were old friends of mine, for I had come across their fathers a quarter of a century before, curiously enough, singing this or a similar song. They were returning home from the battlefields of Bohemia, marching through the lovely pine-clad defiles of the Giant Mountains which led them back into Prussian Silesia. Their dusty helmets, under which shone forth bronzed, fair-bearded, blue-eyed, honest countenances, . were encircled with sprigs of fir. The polished breech of their needle-guns glistened in the sun. When I saw this man in the field I at once recognised him-not only as an old acquaintance, but as belonging to the group of Bismarck mementoes I was in quest of. $\mathrm{He}$ was more to me than the full-length portraits of princes and

* "Brethren, let us clink our glassesLong life to the Reservist ;

A full glass to him

Who has faithfully served his time." 
potentates hard by, for he belonged to the story of Bismarck's career-as the main wheel belongs to the mechanism of a watch. Such as he were the cement of the great structure of German Unity, of which Bismarck, Moltke, and old William supplied plan, initiative, and execution. And such as he shall have a shrine all to themselves in the national Walhalla. No words of blatant glorification shall mark the spot; only the plain inscription that "he faithfully served his time," that he did his duty, shall tell posterity what it owes to the nameless Reservist, whose valour the Germans commemorate in silent yet deathless bronze leaves of oak and laurel in their public places. If Goethe taught the Germans how to live in order that they might know how to die, the Prussian soldier has shown them how to die in order that the country at large might live. He stands for the progress of civilisation of a century: from the days of Frederick the Great, with his army partly composed of mercenaries, drawn promiscuously from foreign countries, to those of a people in arms; an army in which it is reckoned a privilege to serve-a privilege which is forfeited along with other citizen rights by all those who have committed a crime: one of the greatest steps upwards in the morality of nations since the Reformation. It is an additional glory of the Unification of Germany that it was accomplished by such materials: a nation in arms, in which the highborn and the cultured do their duty in the ranks with the lowly. It took a century for the world to 
recognise the significance of the Reformation; it may take another century to do justice to the Prussian army system which made United Germany possible by force of arms. Let no stranger attempt again to come and burn Bismarck's old manorhouse, for he will "get hurt"-even if he is not taken prisoner in the process. In the meantime may the sturdy Reservist long continue to till his field on the peaceful banks of the Elbe. For a nation in arms is a peaceful nation.

On several subsequent occasions, in 1893,1896 , and I898, I came to Schoenhausen again. The Schloss has gained in comfort-it has even been transformed into an abode of luxury; for luxury is the dominant note of our time. The honours of the house are done by a kindly and cultivated hostess; the princely host has ever a warm welcome for his friends. Yet I gleaned no new features at the natal shrine of a hero. 


\section{CHAPTER V \\ VISIT TO VARZIN \\ OCTOBER, I89I}

G ROM Schoenhausen I went on a visit to some 1 friends in Silesia, and thence to Vienna, where an International Statistical Congress was to take place in the latter part of September. It was presided over by a friend of mine, the late Sir Rawson W. Rawson, с.в., who, when still in London, had invited me to act as his honorary secretary for the occasion.

Those acquainted with Vienna are aware that the Austrian capital has lost something of its former busy vitality during the last twenty years, part of which has gone to increase the gay life of its rival, Budapest. Vienna is also fast losing its old characteristic of being an essentially German city. It is gradually assuming a Slavonic character. But Vienna still practises some good old social virtues, among which that of offering hearty and refined hospitality to strangers who come with such credentials as the sixty to seventy statisticians possessed who gathered there in September, I89I. 
We were successively the guests of the Oberbürgermeister at the Rathhaus, of the Minister of Public Instruction, Herr von Gautsch, in his official residence, of the Emperor at a gala performance at the Imperial Opera House, and lastly of the Emperor officially at the Hofburg, where his brother, the Archduke Karl Ludwig, did the honours in his stead, in consequence of His Majesty's unavoidable detention in Bohemia.

There was a strong interest in Prince Bismarck among the German element in Vienna at the time. It was related that the Emperor Francis Joseph, in whose hearing a courtier had recently ventured to express the opinion that it was well for Austria that Bismarck had been dismissed, had said, "If only I had him!" ("Wan i ihn nur hätt'!")

But I came across an even more striking proof of interest in Prince Bismarck in the old Empire City. The Hamburger Nachrichten was taken in, both at the Grand Hotel and the Hotel Imperial, but it was almost impossible to get a sight of it at either place. The paper was always engaged, and thus supplied an unique instance of successful competition with that bible of the newspaper-loving Viennese-the Neue Freie Presse. Again the eagerness which the Neue Freie Presse showed to print my impressions of Friedrichsruh* supplied another proof of the strong interest the Austrians took in everything concerning one whose 1891.

* "Drei Tage in Friedrichsruh," Neue Freie Presse, 2oth September, 
own countrymen had already placed upon the list of the "Aged and Infirm."

Towards the end of a pleasant stay in Vienna I received a letter from Count Herbert Bismarck, from Varzin, saying that his parents would be pleased to see me there-though he regretted that he himself would not be present. He also mentioned that if I came I should probably find the renowned painter, Franz von Lenbach, staying at the house. Little did I anticipate that in Lenbach I should come to find a staunch friend, and also one whose insight into the personality of Prince Bismarck was perhaps deeper and more subtle than that of any other living person. An Austrian friend to whom I mentioned that I was going to Varzin on a visit to Prince Bismarck said, "How I envy you your visit to the sacred glades of Varzin!", ("Die heiligen Waelder").

One afternoon, in the second week in October, I was travelling in a corridor train on the road to Varzin-Prince Bismarck's Pomeranian estate. For many miles the landscape is flat and covered by an endless sequence of red pines of medium growth rising out of a sandy soil. Villages are few and far between, so that the country in some measure prepares one for the vast plains of Poland and Russia further east. To anybody accustomed to the life and variety of West European scenery it is a rather depressing part of the world-one of those regions in which, as they say in Germany, "the foxes bid each other good night." And yet from 
this remote region, in which, however, it is only fair to state that Varzin forms a bright oasis, Prince Bismarck had for months together during many years directed the destinies of the German Empire.

The train was nearing Hammermühle, the little station for Varzin, when, in peering out of the window, I perceived an unusually tall-looking horseman through the dusk. He wore the familiar broad-brimmed black felt hat and a black overcoat. $\mathrm{He}$ rose in the saddle and was riding at a sharp trot along a pathway under the trees-in the same direction as the train. The twilight, the towering figure, and its unexpected apparition, suggested a "Berserker" in these parts. It was indeed Prince Bismarck. This was the first and only time I ever saw him on horseback since that memorable day when he rode through the Brandenburg Gateabreast with Count Moltke and Count Roon in front of the Emperor William-in the victorious throng which entered into Berlin in June, I87 I.

Two elderly ladies were in the carriage, and it occurred to me that they were probably bent on the same errand as myself, and that Prince Bismarck had come to meet them. When the train stopped we found the Prince already alighted from horseback, on the platform awaiting us. $\mathrm{He}$ advanced in his usual courtly manner to greet the ladies, who, it appeared, were both relatives of Princess Bismarck, and coming to Varzin to visit her. Prince Bismarck saw them into a carriage, which was drawn up outside the station. He then asked me to accom- 
pany him and take a seat by his side in another carriage which was also in waiting.

During our drive Bismarck informed me that I would make the acquaintance of his son-in-law, Count Rantzau, but I should probably only see him in the morning, as he had gone out to shoot a roebuck overnight.

I replied that I had read of his own great partiality for this particular form of sport in days gone by, and I asked whether he took no more interest in it and had entirely given it up.

"Yes," he said, "I have long given that up, as well as almost every other form of relaxation. I prefer to see the deer alive to-day instead of drilling a hole in their pretty coat. Besides, politics are like a big trout-which eats up the little trout. For, you know, the trout belong to the predatory, ferox type of fish. Politics have eaten up every other hobby I had."

The Schloss at Varzin is, as far as I remember, about ten minutes' drive from the station; yet it was already quite dark, and the stars were out when we arrived. Twilight changes quickly into night at this time of the year. We were met in the lighted-up hall by Princess Bismarck, her daughter, her children, and Professor Lenbach. The group formed a pretty scene with its background of antlers hanging from the walls-the whole scene impressed me as being representative of a model German country family-gathering in the typical, old-fashioned German manor-house. 
There was a bright stove fire burning in my bedroom-in fact, there were stoves alight all over the house. It was evidently much colder in Varzin than further south, whence I had just come.

At dinner Prince Bismarck sat at the head of the table and Lenbach by his side, whilst I was placed next to Princess Bismarck opposite to them. Everybody was in bright spirits. I still remember that the menu included a succulent fish which is peculiar to the waters of Pomerania, "marena" (marana), and an excellent joint of wild boar shot in the woods of Varzin.

Prince Bismarck told us that the marena are also cured, and in that state exported. He said that people do not appreciate fish half enough as an article of diet, and he instanced several kinds for which he had a predilection. He liked, among fresh-water fish, carp, salmon, and trout, but we all agreed that salmon-trout was an overrated bastard fish, in which the taste of the salmon and that of the trout interfered with each other. Tench, a favourite fish in many parts of Germany, has a muddy taste which he disliked. We all praised the common herring, and it was agreed that if that plebeian fish, instead of being so common had happened to be scarce, people would willingly pay high prices for it, and vow that its flavour is unrivalled-as indeed it is. Another favourite fish of Bismarck's was the Russian sterlet; but more especially he liked Russian caviar. $\mathrm{He}$ told us that when he was ambassador at St. Petersburg 
he once sent the King of Prussia some of the best caviar, but His Majesty never got it; for, as he afterwards discovered, it was consumed by his courtiers.

Bismarck related the story of his well-known feat in oyster-eating. He was once in Liège, where he ordered some oysters in a restaurantfifty to begin with. He saw the lady behind the counter look up in surprise; so, when he had eaten them, wishing to see what effect it might have on her, he ordered another fifty, and so on until he had eaten one hundred and seventy-five oysters. However, it is only fair to remember that in all probability they were the small Ostend variety.

In the course of the dinner I was struck by the intimacy between the Bismarck family and Herr von Lenbach, who seemed to form part of the household. I had previously heard of the Prince's liking for Lenbach, that he was a regular visitor at Friedrichsruh at Christmas-when Germans usually only invite their own near relatives to their houses. I had met people who professed they were unable to understand the reason, since the Prince and Princess took little interest in portrait painting. When I sat with Lenbach at the table of Varzin the riddle solved itself. The gods had cast a rainbow o'er his cradle-the gift of humour. Among other stories Lenbach told the following: An Englishman used to meet the great philosopher Arthur Schopenhauer every morning walking with his ugly poodle along the 
Promenade in Frankfort-on-the-Maine. Schopenhauer's eccentric appearance, deeply immersed in thought, excited the Englishman's curiosity to such an extent that one day he could contain himself no longer, and walking up to the philosopher, addressed him abruptly thus: "Tell me, sir, who, in the name of fate, are you ?" "Ah!" Schopenhauer replied, "I only wish I knew that myself!"

The Prince inquired about my impressions of Vienna. He was rather surprised to find that the Neue Freie Presse had recently made a kindly reference to him, for he thought that the Austrians had taken his opposition to the projected Commercial Treaty very much amiss, and had nothing bad enough to say about him. I told him that, as far as I had been able to discover in Vienna, such was not the case; that he had many staunch friends and sympathisers there; that, particularly the Neue Freie Presse, through its editor, had assured me of its unbounded admiration for him personally, and had specially asked me to convey as much to His Highness.

After dinner we adjourned to an adjoining suite of capacious rooms, in one of which stood a French billiard table, and in another a grand Steinway piano. Princess Bismarck and her daughter joined in a game of "Patience" with the tutor of the Rantzau children, whilst Lenbach and I passed the evening conversing with the two lady visitors. Prince Bismarck as usual read the papers, and now and then looked up and joined in the general 
conversation for a few minutes. The ladies in question were Frau F. Barschall, née von Puttkamer, and Baroness Emma von Besser, also née von Puttkamer, as I am reminded by a note in Princess Bismarck's handwriting. But no handwriting is needed to remind me that they were two highly cultivated women, worthy representatives of the stock which has long furnished warrior sons to the Prussian Army, inculcating a strong sense of honour and duty, a healthy disdain for luxury into their offspring. They were unspoilt descendants of those who contributed their golden wedding-rings to the common fund in the War of Liberation, proud to wear such of iron which the Prussian Government gave them in return. There is still a pride of birth here which is out of fashion in many places, but in their own particular case it did not preclude a due appreciation of intellect and character in others, for both ladies were very proud of the fact that one of their nieces is a well-known authoress, who writes under the pseudonym of "Hans Werder."

After retiring for the night, I had not been many minutes in my room when, with a rap at the door, Professor Lenbach came in holding a sheet of cardboard in his hand. It was the cover of one of those bandboxes in which milliners pack ladies' dresses. Lenbach had given it a lasting value, for he had drawn upon it a pen-and-ink sketch of Prince Bismarck in a forester's cap. He said it was only a trifle; but such as it was 
he asked me to accept it as a memento of our first meeting. He added that if I would come to see him in Munich, he would give me something more worthy of acceptance. It was already past midnight, and in saying good night he told me that he was leaving Varzin next day. In the morning Count Rantzau and I drove to the station to see him off; they were old and intimate friends.

It was still early in the day when we returned, for no one was about. A roebuck which Count Rantzau had shot at dawn that very morning hung in the hall, prior to gracing the dinner-table for our benefit. I took a look round and was struck by the picturesque aspect of the place. The house itself, although by no means pretentious in style, was more in keeping with the character of a nobleman's seat than either Schoenhausen or Friedrichsruh. More particularly was this apparent when viewed from the side overlooking the park, with the handsome glass conservatory, the broad verandah emerging from the clustering creepers which covered the walls up to the first floor. The arrangement of the grounds reminded me somewhat of Schoenhausen. They probably dated from the same period; but they were much more extensive and elaborate. A wealth of limes, chestnuts, beech, pines, and oak trees in promiscuous propinquity gave a rich variety to the scene. The park with its lakes, its broad grass plots, its sombre, shaded groves, here and there relieved by a stone statue, forms a princely demesne, the laying out of which 
in this somewhat arid region must have originally cost a large sum of money.

The division of the day was very much the same at Varzin as at Friedrichsruh. Guests staying in the house were served with breakfast in their respective rooms, and left to their own devices until lunch time, unless asked by Prince Bismarck to join him in his morning walk. Lunch was taken between twelve and one o'clock, when the ladies of the house put in their first appearance. After lunch everybody retired for a short time. Later in the afternoon, about three o'clock, drives were indulged in or rides on horseback. The dinner hour was six o'clock, after which, as at Friedrichsruh, the evening was spent by the whole family together, including grandchildren and tutor, in the suite of apartments on the ground floor.

During my stay at Varzin no other visitorsbeyond the two elderly ladies already mentioned -were present; hence I had Prince Bismarck all to myself. Hence it came about that I saw more of him, and had more opportunities of being in his company than before or since. So much so that before leaving, Count Rantzau, with an amiable desire to make me appreciate my good fortune, said to me-

"I know it will afford you pleasure when I tell you that you have had more of my father-in-law's company during your stay here than I have had since I married his daughter."

Regularly every morning, between ten and eleven 
o'clock, during the five days of my stay a manservant came into my room with the stereotyped message -

"Seine Durchlaucht begs to inquire whether Mr. W. would like to join him in a walk?" Every afternoon about three o'clock the same message was again delivered with the only variation "whether Mr. W. would like to join His Highness in a drive."

In the morning we strolled through the park woods, taking an occasional rest on the benches which we came across in our wanderings. In the afternoon our drives extended some miles in all directions, and the evenings had invariably drawn in, and the stars appeared, when we returned in time for dinner.

Many were the topics Bismarck touched upon during these, to me, unforgettable hours of friendly communion. Some even at this distance of time are best buried in my memory; some again have already been given to the world through various sources; others I have reproduced in these pages. He usually addressed me in English, and I invariably replied in German, although in the course of our conversations we often changed from one language to the other. Very rarely did he use French, except to quote a sentence, although he spoke it perfectly without the faintest trace of a German accent. His French, like his English, reminded me of that of a well-bred Russian.

All Bismarck's utterances were marked by ex- 
treme frankness. I gained the impression at the time that, had I utilised the opportunities to the full which Prince Bismarck afforded me, I might have gathered a sheaf of sensational matter. But the feeling that I possessed his confidence prompted me to refrain from asking him indiscreet questions.

One morning I had just joined the Prince at the door to start upon our walk, when he asked me to come back with him for a moment to his room before we set out. He had apparently forgotten something. In passing through a corridor which led to the new wing of the building in which he slept, I noticed a framed address from some place in Scotland hanging on the wall. It was, as far as I could see at a glance, an illuminated address and testimonial of Scottish sympathy with Bismarck in his struggle with the Pope during the period of the Kultur-Kampf.

The Prince left me for a moment in his study whilst he went into the bedroom which adjoined it. He could not have been absent more than a couple of minutes, during which I looked round the room, taking stock of the various interesting things it contained. My eye fell upon his writing-table; a Bible lay wide open at the Book of Job, chapter xxix. Bismarck had evidently been reading it that very morning, for it lay open in front of his seat at the table. I had previously heard that Job and Isaiah were his favourite books in the Bible. The Old Testament formed part of his regular reading.

I was looking at an illuminated crest in the 
middle of the mantelpiece when the Prince came back into the room. The motto was the one which I had always understood to be that of the Bismarck family, "In Trinitate robur." But he told me that whereas the oak and trefoil leaves were part of the old family crest, the motto was of recent date. He himself had hit upon it. On some occasion, many years ago, when a high decoration had been conferred upon him by some potentate, he was called upon to designate a motto to go with the crest to be entered in the records of the said Order, and he chose that one.

In further conversation I mentioned that this particular part of the Schloss and its sumptuous decorative style reminded me of some rooms of Count Schaffgotsch's beautiful old Schloss at Warmbrunn, in Silesia, which had been renovated at great expense.

"Yes," he said, "I had originally intended to have the whole place rebuilt, but when I had finished this wing I discovered that it would cost too much. I could not afford the money to spend on it, for I lost a considerable sum years ago merely through a view I took of my official position quite independently of any consideration of profit or loss. I had invested what was a large amount for my circumstances in Russian State Bonds. Shortly afterwards our political relations with Russia became somewhat strained. Although I did not feel the slightest anxiety concerning the stability of Russian values-in which I have always 
had unabated confidence-I did not think it consonant with the etiquette of my position as German Chancellor to be personally interested in Russian Stocks at such a critical juncture. So I gave instructions to Bleichroeder to sell out my holding. He implored me not to sell, and I felt that he was right. However, I still adhered to my resolution, and it cost me a good round sum of money, for at that particular moment all Russian securities had gone down very much. That loss I never made up again."

In turning to leave the study we passed the door leading to the bedroom; Bismarck opened it to show me his sleeping quarters. The apartment contained a plain wooden bedstead, a bath tub, a weighing machine, and a gymnastic apparatus, which he used by Dr. Schweninger's orders. There was nothing of ornament or luxury ; extreme tidiness, an almost Spartan simplicity, marked the room. Pointing to the apparatus, I congratulated the Prince on his vigour that he could still take gymnastic exercise at his time of life. He replied that he did not think that meant much, and that he did not expect to live much longer. I instanced the age of the Emperor William and Moltke, and that he had as good a chance of long life as they.

"Oh, no," he said, "Moltke was a very moderate man all his life in everything, and I have always burnt the candle at both ends, particularly in my younger days." I thereupon related a well-known Scotch story of the uncertain connection between 
temperance and longevity and, per contra, self-indulgence and short life. This story seemed to amuse Bismarck. But he continued that he did not trouble himself much about his own chance of attaining a great age-he hardly cared when his life came to an end; that he was more anxious about his son William, who, he was afraid, would not live to be an old man. But what went nearest to his heart was the state of health of his wife. And he added in a sad undertone, as if to himself, "If she is called away, I do not wish to remain behind."

In the meantime we had walked out into the grounds, and, after a long stroll, sat down side by side on a bench shadowed by some trees.

Whilst still in Vienna I had bought a couple of plain natural-wood walking-sticks, each with a bent handle and a steel point, such as are typical of Alpine sticks. By their combined lightness and strength they made admirable walking-sticks. When making the purchase for a few kreutzers, I had already harboured the intention of offering one of them to Prince Bismarck, and had picked out the longest of its kind in the shop in the Opernring.

But how to offer the Prince such a trifle when I knew that he already had such a large assortment of walking-sticks, some costly ones mounted in gold, silver, and ivory among them! Besides, with all his affability, there was something about him which made one feel that it was almost an impertinence to offer him anything, whether a dukedom or a stick. 
There seemed only one way, and that was to see first whether I could interest him in the peculiar nature of the wood, for, as it happened, no one in Vienna could tell me what wood these sticks were made of. So, seeing my opportunity, I held the stick I had in my hand towards the Prince, and asked him whether he could tell me what wood it was. He looked at it, and familiar as he was with many kinds of wood, this peculiar sort seemed to puzzle him.

"They tell me it is a Hungarian variety of oak," I said.

"Well," he replied, taking it out of my hand and tracing some figure on the sandy soil, and then passing it back to me and then taking it from me again, "it seems to me that the wood combines the lightness of the vine with the solidity of the oak; but it has not the exact character of either the one or the other. It is a very nice stick, all the same," he added, continuing all the time alternately to examine its texture and to test its strength by placing both his hands upon the handle and leaning with his whole weight upon it. It was often the Prince's wont to sit thus when sunk in thought. His large blue eyes wandered far afield over the horizon, and an expression of intense sadness passed flash-like across his features. $\mathrm{He}$ reminded me of a caged eagle. There was something of lofty-yet unutterably pathetic-solitude about him.

"It is almost a piece of presumption on my part, 
Prince Bismarck," I said, "to ask you to accept such a trifle, especially as you possess already such a number of beautiful sticks. But, to tell you the truth, I really brought this particular one with me in the hope that you might take a fancy to it. It is so plain and yet so solid that I thought you would like it. I have bought another for my own use, and it would afford me very great pleasure if you would accept this one."

"Certainly," he replied, "I shall be very glad to have it and to use it, for it is one of the most sensible sticks I have seen."

Henceforth he regularly carried that stick, and as often as I saw him again in life, if out of doors, he usually had it in his hand, and more than once held it up to me with the words, "You see, I have still got your stick."

The other stick which I had with me was also, in a certain sense, identified with Prince Bismarck, for he now and then held it in his hands when in the course of our walks we occasionally exchanged sticks in the intervals of conversation and of drawing figures in the sand. On my return to England I had a silver band put round it with the word "Varzin" engraved upon it and presented it to the English historian, James Anthony Froude, with whom I was on friendly terms. $\mathrm{He}$ was a staunch admirer of Prince Bismarck and valued the gift. He used to carry that stick as long as he lived when he took his morning stroll through Onslow Gardens, South Kensington. 


\section{CHAPTER VI \\ VISIT TO VARZIN \\ (CONTINUED) \\ OCTOBER, I89I}

ISMARCK'S love of country life was familiar
to me from my previous visit to Friedrichsruh, but in Varzin I was struck by a deeper note of his attachment to the soil. Varzin, there could be no doubt, was his favourite abode. He seemed to take even greater pleasure in showing a visitor the sights in the neighbourhood than at Friedrichsruh. In walking through the park his eyes would wander from tree to tree, as they might do in a crowd among whom we instinctively expect to meet acquaintances. I fancy he knew some of his Varzin oaks and beeches by sight, and was glad to see them looking well and flourishing on a fine autumn afternoon. We were also ever on the look out for deer and wild boar. Some of the latter we encountered more than once.

On various occasions we inspected the fisheries, the farms, the saw-mills, the paper-mills, and even the village schools. We walked into a schoolroom 
one day-some miles from Varzin. It was empty; but the Prince wanted me to see it, if only for the sake of its spick-and-span tidiness. He took a great interest in these schools, for here in the Volksschule the Teuton idea was first taught to shoot, which has made such a stir in the world during the latter half of the nineteenth century. We also called on the pastor of some village, but everywhere we went I was struck by the absence of servility among all we encountered. Domestics, labourers, foresters, mechanics, pastor, or postmanin whose eyes Bismarck must have appeared a very great personage indeed-with all of them it struck me that attachment held the balance to the sentiment of awe which his appearance inspired.

One afternoon at sunset we stood on some rising ground, whence we obtained a clear view of the country around. Bismarck told me that the estate had once belonged to a family of the name of Zitzewitz. The Zitzewitzes, from being plain junkers in course of time, became counts, and subsequently died out. This same fate had befallen several other Pomeranian noble families after they had been made counts. Bismarck himself at one time had half harboured the fear that the like might befall his own house. Thus he said, if he were really inclined to be superstitious, he might deem it lucky that his family had since changed its status to that of a Prince. He pointed out a town in the distance, which he told me was Schlawe. He said that in the winter the crows and jackdaws 
from Varzin gathered together there, and for aught we knew to the contrary, carried on all sorts of games-indulged in courtship and marriage, went through rejoicing and sorrow, like any community of human beings.

Bismarck told me that for so many years he had never been able to go about without being noticed. Thus, when in Berlin, it would have been a distraction and beneficial to his health to have gone now and then to the theatre. One of the reasons why he never went was that he did not wish to provoke demonstrations, whether of popularity or the reverse. He would have liked, I think, to go about unnoticed, unseen, like Harun al Raschid.

Bismarck's story of King William's despondency in the early days of "Conflict-Zeit" is well known. In relating it to me one day he said-

"Yes, I found royalty in a bad way; it was too weak for what is required under our monarchical conditions. Now and then I fancy I have been the means of making it a little too powerful, at least for a time. Have you heard the story of the rider who could not get on his horse, and called upon his patron saint to help him into the saddle?"

I pleaded ignorance.

"Well," he continued, "the patron saint came to his assistance and gave him such a powerful 'lift-up' that he vaulted clean over the saddle on to the other side 'of his steed. 'Gently, don't be so vehement,' cried the rider. That, you see, was something like my action with regard to royalty. 
I now and then fancy I may have been too vehement" (heftig).

The Prince lapsed into thought for a few moments, and turning towards me slowly recited in faultless English the well-known passage in Shakespeare's Midsummer Night's Dream.

"Let me play the lion too: I will roar, that it will do any man's heart good to hear me: I will roar that I will make the Duke say, 'Let him roar again, let him roar again.' There was a touch of sarcasm in the tone of his voice which had scarcely left it, when in referring to an episode connected with his dismissal from office* he recited the two following lines:-

"Jussuf, der Neger aus Darfur

Reicht grüssend ihm die seidene Schnur." †

Bismarck deplored a lack of character among his countrymen, and said that sometimes he fancied he was partly to blame for it. The nature of his task in strengthening official and regal authority had, like every other earthly thing, brought disadvantages in its train. It was perhaps answerable for the deplorable lack of "backbone" in Germany, for the growth of the type of the Streber (striver, or time-server), the man whose only aim is selfadvancement at any cost, self-respect included.

* The peremptory message Bismarck received from the Emperor on the 17th March, 1890, asking for the immediate delivery of his request in writing to be relieved of his offices.

+ "Jussuf, the negro from Darfur, Hands him the silken cord with a smile." 
The restless trend of affairs, the admittance of irresponsible advisers in high places, the demonstrative publicity with which readiness to curry favour with those in power is recognised and effusively rewarded-all these things filled Bismarck with concern as tending to render honest service rare and to foster those qualities which are known under the designation of Byzantinism. Bismarck's intense dislike for German Liberalism was connected with his contempt for the Streber, a goodly number of which he had encountered among Liberals; more particularly the liberalising professors and privy councillors who had endeavoured to gain the ear of the Crown Prince and his wife in days gone by. $\mathrm{He}$ detested these pseudo-liberals. There was, however, nothing in the term or essence of Liberalism in the concrete that need have permanently aroused his enmity. For years the National Liberals had cordially worked with him-and he himself was more liberal in some senses than many of those who sailed under Liberal colours. His grievance against Liberalism was not so much its representing any particular set of ideas, but the insincerity of what it professed.

It was a similar connection of ideas which set him against Irish Home Rule-as much as he ever was against anything about which he knew little and cared less. For what little knowledge he may have possessed of the question he had gained second-hand. It was no business of his, and his interest was never more than lukewarm in things 
HIS OPINION OF MR. GLADSTONE 85 which did not concern him. He said to himself the English have certain traditional methods of dealing with other people. In the American colonies they were answerable for England losing the United States. Ireland being nearer and less capable of resistance, these methods have only resulted in creating a festering, running sore, and in Ireland being the only country in Europe, perhaps in the world, which has lost a third of its population in the course of the last hundred years, during which many others have increased theirs in proportion. But to believe that $\mathrm{Mr}$. Gladstone, who in his younger days had championed the slave trade, should suddenly have become converted to the wrongs of Ireland was asking too much of Bismarck's credulity. It seemed to him more likely that it was a party manœuvre, "baksheesh" for the Irish and in return a generation of Liberal victories at the polls; therefore a crowning instance of pseudo-Liberal trickery. He pleaded guilty to having in his day cajoled-bribed, if you willparliamentary parties in order to gain their support, but he had not stumped his country and tried to make it believe that in so doing he was carrying out a righteous mandate of heaven.

Bismarck told me that he used to admire the fearless independence of the typical English gentleman, and cited one or two historical instances which he thought illustrated this quality. But since he had heard that their land was going out of cultivation and that they have taken to drink water, he 
was afraid things had changed in that respect too. It was not that he believed any particular virtue per se to be inherent in alcoholic drink; more than once he told me that Bacchus and Venus do not go well together. But it took strong men to stand strong drink. He for one declined to believe that the renowned old English "three-bottle men" were inferior to their descendants. Bismarck had a suspicion that the fashion of drinking water arose more from a dread of the deleterious effects of alcohol than from any suddenly developed sense of sobriety, and that it meant a shrinkage in those dare-devil qualities of the English race which had made them what they were in the past, and for which he had always felt a sincere admiration.

I replied that with regard to the water-drinking proclivities of my countrymen, and more particularly my countrywomen, there was a deal of calumny connected with the story. Unhappily for the wine and spirit dealers, it is true that a certain section of English society has indeed taken to water as an habitual beverage. But to argue therefrom that the English people had become addicted to water would be to draw premature conclusions from insufficient data. It would, by analogy, be tantamount to argue that because the German Ocean is encroaching on certain parts of the English east coastline, therefore England is going to be drowned in salt water, whereas it is well known that at other parts of England the sea is being forced back by the rising of the shore. Water-drink- 
ing in England is no more than this. There are still millions of Englishmen who would resent being restricted to water, and among the most sturdy partisans of alcohol are many Englishwomen, as every medical practitioner and hospital nurse is in a position to prove. I also pointed out that for every water fanatic who holds a seat in the British Parliament there are a number of brewers and whisky distillers. The fact that several brewers are popular members of the House of Lords is in itself evidence sufficient to show the high esteem in which alcoholic drinks are held in England. Finally, in order to calm Prince Bismarck's fears with regard to what the future might bring forth, I added that although fifty years ago a considerable portion of Ireland had been perverted to drink water by the efforts of a Roman Catholic priest known under the name of Father Mathew, I was able to assure His Highness that things had since found a healthy level, and that to-day the Irish drink as hard again as ever.

Prince Bismarck smiled approvingly at the patriotic fervour with which I had sought to defend the bibulous propensities of my country, and our conversation reverted to the subject of royalty.

Bismarck knew something about royalty in general ; more particularly about that international royal freemasonry which is such an important feature of monarchical influence in our time and has produced so strong a feeling of trade solidarity among kings that their sympathies are often nearer 
to those of their class in other countries than to the most worthy among their own subjects. Never before has there been such a sense of trade-unionism, of identity of interests, among royalty, as now since the republican form of government, in Europe as well as in America, threatens their future more than ever.

I fancy Bismarck never emancipated himself from inherited tradition, which made him look upon the least distinguished representative of royalty as something different from common clay. A visit from an obscure scion of a royal house was still an honour in his eyes such as only royalty could confer. Needless to say that with him this traditional feeling never interfered with the exercise of his critical faculties when so inclined. Thus Bismarck had a distinct antipathy towards the royal houses of Orleans and Coburg, Not that this was called forth by or directed against any single member of either of those two august houses. It was aroused by certain qualities which Bismarck had observed in the course of time and which he had come to identify as characteristic of these two royal families ; more particularly that of Coburg, for the other concerned him less.

Taken all in all, Bismarck was agreeably surprised at the patriotic conduct of the German sovereigns under the new order of things. From their point of view, he said, they had made great sacrifices in consenting to the creation of the German Empire, and might naturally have been expected to feel that such 
was the case. But they had disappointed the fears he had harboured concerning them; and in the Federal Council, where a strong influence is reserved to them, they had invariably used it in a judicious and patriotic spirit. More particularly King Albert of Saxony had earned his high esteem ; for the royal house of Saxony had been the one with regard to which he had had most misgivings. The Grand Duke of Baden, however, was not latterly, I think, one of his favourites. For Bismarck believed that the Grand Duke had had a hand in the intrigues which culminated in his dismissal. "If anything, I feared the princes and trusted the people," he said. The growth of Socialism was to him the bitter outcome of his trust in the latter. A crowning instance of national ingratitude; more particularly after his strenuous efforts to secure more tolerable conditions for the mass of the people in their old age. Socialism was the one topic I was afraid to broach, for my reading of history had brought me to believe that, unless you are absolutely certain to be able to crush an idea by force-as, for instance, Pope Innocent the Third exterminated the Albigenses and Louis the Fourteenth effaced Protestantism from France by the revocation of the Edict of Nantes-it is a hopeless task, particularly in our time, to combat by repressive laws an idea which is held by millions of men in possession of vote by ballot. How are you going to treat them permanently as outlaws? In Friedrichsruh I had already once asked Bismarck whether he was still in 
favour of a continuance in force of the repressive Socialist law? He had replied that he was. In Varzin I again asked the same question, and he replied, "Of course I am. People who aim at the subversion of the State must be met with the full powers of self-assertion possessed by the State. The Socialists want what can never be conceded. You cannot rule a country from below. This is impossible, for it is against the natural order of things. Sometimes I wish that my successors would try an experiment with the Socialists, and they would soon find out the hopelessness of the task."

When I drew Prince Bismarck's attention to the impossibility of withdrawing the voting power the Socialists already possessed, he replied that constitutions were only the work of man (Menschenwerk), and as such were subject to human revision. $\mathrm{He}$ did not believe that the progress of mankind is always necessarily concurrent with an extension of privilege to the individual. $\mathrm{He}$ could well imagine progress harmonising with its curtailment - the yielding up of a part of the free disposition of the unit for the benefit of the aggregate; as is, for instance, exemplified in Germany by universal military service. This has secured peace and prosperity besides a number of other benefits to Germany.

I do not believe that Bismarck quite realised the ethical side of Socialism. The ethical side there needs must be in all great movements that affect the conduct of millions, and this notwithstanding 
his own deep interest in ethics from his early days as represented by Kant, Hegel, Spinoza, and, above all, Christ. Thus Herr von Vollmar, the Bavarian Socialist, was in Bismarck's eyes nothing but a standard-deserting renegade, a perjured scoundrel, who had broken his officer's oath of fealty to the King of Bavaria, and who, as a matter of policy as well as of sentiment, ought to be shot. The thought that a man such as Herr von Vollmar, who belonged to a good family, held the honoured position of an officer, of one, too, who had taken his part in the Great War of 1870, might not be playing the part of a vain charlatan-but in the same way as Bismarck himself, staking his full personality on what his conscience told him to be his duty towards his fellow-men, such an idea did not and could not enter Bismarck's head. The statesman was paramount, and was bound to be. He had no room for weighing theory or sentimental considerations in dealing with such phenomena. The narrow limits of human nature do not allow of such a figure as Bismarck was, who at the same time would have extended a tolerant hearing to an Arnold of Brescia. To a Bismarck of that time, and in this particular Bismarck was of a past time, such a man-yes, even a Christ or a Spinoza -would have appeared, and would have been bound to appear, the one a dangerous Socialist, the other a Jewish renegade- "ein Umstürzler." Not that Bismarck was intolerant-far from it. It was the politician in him that could not allow 
irresponsible theory or theorising, there where, according to his view, the very existence of the State was at stake. The archetype of the stern man of realistic action could not be expected to meet the other extreme of transcendent theory in a dispassionate spirit. Even as it was he had been obliged in other days to violate the spirit if not the letter of the Prussian Constitutionto act for a time as if his opponents, the parliamentary majority, had no legal status-if he was to achieve what he did. And yet without that daring stroke of statecraft it is doubtful whether Germany would be united to-day. Now if the industrial development of Germany had set in a generation earlier and Socialist power had already been in 1860 what it is to-day, who can say that even a Bismarck would have been able to carry out his plans in face of such opposition as he would certainly have encountered? Thus in Germany it was necessary to have a man who united genius with the toleration and culture of his time, which Bismarck did indeed possess, and yet with something in addition of the stern, uncompromising severity, in the face of political opposition, of another age. In the United States the marvellous stability of the political fabric has hitherto been able to allow free scope to every kind of political, social, or ethical propaganda; and this because the majority is certain to turn on the minority as if they were so many mad dogs as soon as they should become inconvenient. And this may yet 
come to pass. Or, again, in England, where formerly, strange to say, every kind of schism was ruthlessly persecuted, to-day the firmly rivetted social structure-some call it the stagnation of ideas-is such that the twelve apostles might safely be allowed to preach Socialism from the housetops with the certainty of shortly finding themselves in the workhouse for want of a living. In Germany political as well as social conditions are different. They do not possess the same cohesive homogeneity or stability.

Once convinced that Socialism is an enemy which it is impossible to conciliate, it only remained to be combated. Could Bismarck have believed that Socialism were harmless, or to be conciliated, he would have been pleased to conciliate it and so to cultivate personal relations with the Socialist leaders - several of whose records are of such a nature that Bismarck could not help respecting them. In fact, Bismarck's "objectivity," his superiority above the mere personal element, was such that he would have always welcomed the Socialist leaders had they been willing to come, as he welcomed Windhorst - perhaps a more dangerous enemy than any Socialist. As it is, Bismarck made a new departure in German political life by receiving his parliamentary opponents as welcome guests in his own house: hitherto a thing unheard of. I only know of one man against whom he harboured an antipathy which precluded personal intercourse, and that was because 
Bismarck did not consider him fit company for a gentleman. Unfortunately this personal contact with the Socialists never took place, nor could ever have taken place. I had met Bebel in Berlin and could understand why a meeting was impossibleit did not depend upon Bismarck, but upon the Socialist. Whereas it is not easy to imagine a living Englishman, born of an English mother, declining an invitation from Lord Salisbury - a Bebel was not to be cajoled or brow-beaten. Centuries of class hatred, of class oppression found fiery expression in that man. Such passionate resentment could not exist in the heart of an aristocrat whose ancestors had always held the "whiphand" of the social and political chariot. A Bismarck could afford to forget; it is the others who insist on remembering.

I never touched upon Socialism again in our conversations. My observation of the German national character, more particularly as far as Saxony is concerned-which is the most socialistic section of Germany-had gradually but irrevocably convinced me that Socialism is the inevitable outcome of German industrialism, in contact and interaction with the peculiar character and education of the German masses and more particularly the intellectual proletariate which largely permeates and influences the masses. In England the influence of a half-educated agitator is restricted to his capacity and opportunity for platform oratory. $\mathrm{He}$ gets little hearing or excites little personal interest 
THE FUTURE OF GERMAN SOCIALISM 95 among the masses in daily life. In Germany this is very different. The small official, who has probably passed through a gymnasium, is an authority looked up to in the beerhouse. He even organises the summer Sunday outing of the artisan and his family. Socialism would have come to the surface sooner or later in some form or other, even if Lassalle, Marx, Bebel, and Liebknecht had never lived. Socialism would become a real danger if its theories should ever secure the support of the great ethical forces of the country; in other words, claim the German Universities. This would mean a revolution of possibly more far-reaching consequences than that of 1789 . It might bring about the advent of a new era in the history of civilisation such as was the Reformation, and probably, as in that case, the running of rivers of German blood. This might in its turn lead to the political downfall of Germany as a Great Power, for she would be called upon to pay for the second time the tribute of blood nature always exacts for the progress of mankind. The hope of the future must lie in German Socialism gradually, as one generation gives way to another, modifying its extreme theoretical character in accordance with the possible conditions of German life, and that the Socialist party may come more and more to represent the legitimate aspirations of the labour party of the country. That the German Insurance Laws, of which Bismarck was the originator, should and will tend in that direction is, I think, a wide- 
spread conviction. But I instinctively shrank from challenging his opinion further on these points. I thought he might not like to discuss the subject with a foreigner; though now that ten years have elapsed, I am convinced that I was mistaken. There was indeed no political or personal topic, the discussion of which, if Bismarck happened to be in the humour, came amiss to him, and that without the faintest suspicion of sensitiveness of any kind, even when fraught with painful memories. On another occasion Bismarck mentioned the two attempts which had been made on his life. He told me of Cohen, who shot at him in 1866 Unter den Linden; that two shots from Cohen's revolver passed through his coat. After he had grappled with his assailant, a couple of soldiers who seized hold of the assassin were about to ill-treat him. Bismarck called out to them, "Don't hurt him ; we want him alive. He is of more use to us alive than dead."

Bismarck always remained convinced that Roman Catholic priests incited Kullmann to make his attempt at Kissingen, and were even present on that occasion to see he carried it out. He told me that there were several priests among the crowd, and that on seeing one he even called out, "Stop that priest!" but in vain. Kullmann fired five shots at him, two of which struck the back of the carriage.

After Hödel had made his attempt on the Emperor, the first words which old William uttered were, "Why, I don't even know the man!" 
Speaking of old King William, Bismarck told me that it was impossible to imagine a position, however trying, in which he did not look and indeed was every inch the King. Even in deshabille, in bed, old and worn out, when shot at by Nobiling and wounded by small-shot as if he were a pheasant, there was always something dignified about him, which differentiated him from other people. The King's gracious courtesy was indeed at all times remarkable-and, unlike that of some other monarchs, it was absolutely spontaneous and innate.

One morning I asked the Prince how he had slept the previous night.

"Indifferently," he replied, "but unfortunately this is nothing unusual with me. I have had bad nights for many years. Formerly, when I was in office the slightest thing assumed vast proportions at night and lay like a mountain on my chest. I used to lie awake for hours unable to shake it off. I would begin to think out parliamentary discussions and would get up and make notes of what, under certain circumstances, I should say. In the morning, however, I invariably found that my notes were of no use. Latterly neuralgia is the principal cause of my sleeplessness."

To my query whether he thought he had really tried every possible remedy, he smiled somewhat sadly and said-

"The Empress Frederick once told me-presumably to console me-that she was sure I should never get rid of my neuralgic pains, for she had H 
long suffered from them herself and she had tried every remedy in vain."

I remarked that I could not quite understand the point which people, both in Germany and in England, were so fond of making of the Empress Frederick's English nationality. She was almost entirely German by blood; the English Royal Family had been essentially German in their home life in her younger days, her father's influence having been decidedly German. German had been the language currently used in the English Royal Family, and I always understood that the Empress Frederick herself spoke English with a strong German accent. In fact, she was more German by family training, the impressions of the nursery, than many a thorough-bred German of my acquaintance who had been brought up by English governesses with a predilection for everything English.

"Yes, indeed," said Bismarck, "but there are Germans who are far more English than the English themselves. It was the Empress's misfortune that in her position she felt herself to be an Englishwoman."

The Crown Princess had brought up her daughters with a strong feeling of attachment for England, together with a conviction of the superiority of everything English. Thus, they always spoke English by preference, and when on a visit at German Courts would sign their names in the visitors' book in English as "Princess of Prussia." The story went that one day their brother William 
-the present German Emperor-heard his sisters exclaim that they longed to "go home." He asked them what they meant by "home." They said, "Home to England, to grandmama!" Prince William rebuked them thus: "Now let me tell you this, I am a Prussian Prince and you are a couple of geese." The Crown Princess now and then made disparaging remarks about German things, which ill-natured gossip eagerly laid hold of and enlarged upon. Thus during the illness of her husband at San Remo some British ships appeared in sight, and her expressions of delight were interpreted in an invidious sense. These and many other stories had been brought to Bismarck's knowledge. Although they could not be pleasant to him, he made no comment, but he regretted the frame of mind which called them forth as being an unfortunate one for all concerned.

In the course of conversation concerning foreign influence in Germany a pamphlet was mentioned between us entitled Mitregenten Und Fremde Hände in Deutschland.* It was published in Zurich in 1896 , and its authorship was commonly attributed to Duke Ernest of Coburg, although I am not aware whether it has ever been admitted. Bismarck was acquainted with the pamphlet in question, and told me that he believed the Duke was the author, but, whether he was so or not, the facts it contained were not what he was in the habit of terming "Coburg facts" (i.e. tortuous sophistries),

* Zurich, 1886. , Verlags-Magazin (J. Schabelitz). 
but a bona-fide statement of a condition of things existing in Germany.

A chance had put me in possession of the secret of the authorship of this particular pamphlet at the very time it first appeared-long before any outsiders could possibly have been aware of its real origin. In I886 I was in Dresden, when I received a telegram from a distinguished man of letters still living, who was a personal friend, and at that very moment a guest of Duke Ernest of Coburg. His message was to apprise me that he would arrive in Dresden that evening. We were old friends, and on his arrival he gave me a copy of the pamphlet Mitregenten to read, with the words, "The Duke gave me this at parting as his own work. $\mathrm{He}$ is very bitter about the family influence of Queen Victoria in German affairs."

Bismarck referred to the Duke of Coburg's antipathy towards Lord Palmerston, and the Duke's delight when, one day at Windsor at a meeting of the chapter of the Order of the Garter, the English statesman, who was then already an old man, stumbled and nearly fell. Lord Palmerston was extremely jealous of foreign influence in England, more particularly that of the Duke's brother, Prince Albert. Prince Bismarck said that the English, with their great national history, their strong insular feeling, were naturally sensitive with regard to foreign influence in their midst, and he only wished that the Germans were a little more like them in this respect. The Prince Consort had 
brought ideas of his princely prerogative with him from Germany which did not accord with those to which the English aristocracy were accustomed : the less so, since many English noblemen looked upon themselves as every bit "as good" as a German prince. The prominent part which the leading families of England had played in the making of the history of their country was quite sufficient to explain the sentiment. "On one occasion," said Bismarck, "Prince Albert was out pheasant shooting with some guests, when a pheasant fell to a shot in his immediate vicinity. The Prince Consort turned to one of his gentlemen-in-waiting and asked who had thus taken the liberty of firing before him. The guest in question was pointed out to him. Thereupon Prince Albert caused it to be intimated to him that he had been guilty of a gross breach of etiquette, and that he must retire at once from the shooting party. This incident got bruited about, and created bad blood at the time, for such treatment of a gentleman and a guest was unheard of in England. It was possibly in connection with, if not a direct consequence of, the above, Prince Bismarck added, that the Prince Consort once met with a severe rebuff at the hands of a member of the English aristocracy. One morning Prince Albert joined the meet of the Royal Buckhounds near Windsor, the members of which were only awaiting the arrival of the master of the hunt, a very big social personage in England, in order to start the hounds. However, as this 
functionary was late and had not yet arrived, the Prince Consort took upon himself to give the necessary order for the hunt to begin; and this was duly carried out. Shortly afterwards, whilst the hounds were still in full hue-and-cry, the master came galloping along, and hearing what had taken place, at once gave peremptory orders for the hounds to be called off and the hunt to be suspended for the rest of the day; and turning his back on the party, galloped off without further ado. Prince Albert was furious. He rode straight back to Windsor Castle and complained to the Queen, who shared her husband's indignation. She sent for Lord Palmerston, who was Prime Minister at the time. When he arrived at the Castle the Queen insisted that he should immediately call upon the Master of the Buckhounds to resign. Lord Palmerston could not very well refuse point-blank to comply with such a request, but he told the Queen that if this was indeed Her Majesty's pleasure, he saw no alternative but to place his own resignation, as well as that of all his ministerial colleagues, in her hands. The Queen was fairly taken aback at this turn of affairs. She shrank from what she was well aware would have caused a great commotion throughout the country had it become known that the Prime Minister had resigned from such a cause. She was, therefore, for the time being at least, obliged to condone the siight put upon her husband.

I told Prince Bismarck with what fascination I 
had studied some of the most dramatic and fateful episodes of his life-his refusal to join the Frankfort Princes' Congress; the critical diplomatic negotiations concerning Schleswig-Holstein; then again the story of Nikolsburg, and his "dilatory tactics" with Beneditti after I 866.

He said, "Yes, they were somewhat exciting times, more particularly for my nervous system, but there was also some fun connected with those days, now that I think of them." Bismarck said that the old King of Denmark, Frederick the Seventh, was subject to lapsus memoria in a similar way to George the Fourth of England, when the latter used to relate his prowess at the Battle of Waterloo to the Duke of Wellington. The King of Denmark told people that he had sworn to his father to maintain the Danish Constitution, which had no existence at that time, for it was only promulgated after the latter's death.

One of the Danish King's other stories was that he had worn his helmet for three days and three nights at the siege of Friedericia, in I849, at which he had not even been present.

In regard to events connected with the campaign of 1866 , Bismarck said, "My two great difficulties were first to get King Wilhelm into Bohemia and then to get him out again. Once the King had tasted the sweets of success, he became more difficult to manage, and was particularly averse to grant either to the Saxons or the Austrians the terms I proposed. He was also full of reactionary 
ideas.* Herr von Kleist-Retzow was his inspirer in this direction. On our way back from Prague to Berlin, I had all my work to bring him to my way of thinking. The Crown Prince was with us in the carriage, and tried to convert his father to my views, with which he agreed. Reactionary rule would have meant a hotbed of Austrian intrigue in every small German capital."

Among the petty German Courts which in 1866 had been most violently anti-Prussian was that of the Grand Duchy of Hesse-Darmstadt. After the outbreak of the war, when affairs were already going badly with the South Germans, the Grand Duke vented his pent-up feelings by kicking a Prussian helmet about the room, and vowing that things would not mend before the Red-Trousers (the French) were called into the country. Bismarck told me that a very disagreeable habit of rinsing the mouth at table was indulged in at the Grand Ducal Court; whereas those guests who did not belong to exalted rank were expected to look on with mouth unrinsed.

Bismarck said that when he went to the Paris Exhibition in the year 1867 , the impression he gained there tended to confirm his belief that a war between France and Germany was sooner or later inevitable. One day Marshal Vaillant, who was Minister of the Imperial Household, called to see

* I fancy this referred to Bismarck's proposal to seek indemnity from Prussian legislatures and the King's hesitation to adopt his view, but my notes do not show whether such was the case. 
him and expressed an opinion to the same effect. Bismarck, out of courtesy, endeavoured to dissuade him, but Vaillant replied-

"Non, non, croyez moi, nous autres, nous sommes comme le coq qui ne tolère pas d'autre coq près de lui. La Prusse est cet autre coq, et il faudra que nous croisions l'épée."

"Eh bien," replied Bismarck, "dans ce cas croisons."

I had long harboured an idea that the real hero of the Berlin Congress was neither Prince Bismarck nor Lord Beaconsfield, but the Chevalier de Blowitz. For whereas Bismarck had only played the uninteresting part of an "honest broker" and Lord Beaconsfield had been obliged to rest satisfied with a compromise with Russia, the gifted correspondent of the Times achieved next to the impossible; he surpassed himself. He beat his own record by sending the Berlin Treaty to the Times before the original draft was even signed. What Prince Bismarck told me at Varzin confirmed me in my surmise as to the prominent part played by this prince of journalists at the Congress. The Prince said it was urged in a certain quarter that the Chevalier should receive some mark of distinction from the Prussian Government. Bismarck suggested that the third class of the Order of the Crown would meet the case. In a certain quarter it was objected that the second class of that august Order would be more appropriate. Bismarck replied that hitherto no journalist had ever received so high a distinc- 
tion; on the other hand, it could not be gainsaid that there was only one de Blowitz in the world. So he decided to refer the matter to Lord Beaconsfield. "Give him the second class," said Beaconsfield coaxingly, and the Chevalier got it.

I drew Prince Bismarck's attention to the portraits of George Bancroft, General Grant, and other distinguished Americans, which I had seen either at Varzin, Schoenhausen, or Friedrichsruh. For there were apparently more portraits of Americans in his possession than of men of any other nationality. This struck me all the more forcibly since the only pictorial memento I had seen of the nationality he admired so much in early life-the English-was a portrait of Lord Beaconsfield. I gleaned that his personal relations with Americans he had met in the course of his career had invariably been of a most cordial nature. Nearly all of them were attracted to him by the charm of his manner. They admired his character. Bismarck's intimate friendship with Motley, the historian, is well known.* $\mathrm{He}$ was also particularly attached to George Bancroft, so that when it became a question of Bancroft being recalled from his post of United States Minister at Berlin, Bismarck wrote specially to his friend Motley and begged him to intercede with the President to allow Bancroft to remain; and he did remain. Bismarck told me that when General Grant came to Berlin he accompanied him to see one of the reviews at the * See Correspondence of J. Lothrop Motley. London, Murray. 
Tempelhofer Feld. Grant was not well that day, and they had to drive out in a closed carriage. Grant looked downcast, and told Bismarck that it worried him to think that he was to meet the Prussian soldiers sitting coddled up in a carriage like any ordinary civilian. "Never you mind that, General Grant," Bismarck said, "you may sit here hidden from view, but our soldiers are well aware what sort of fighting man is in this closed carriage." 


\section{CHAPTER VII}

\section{VISIT TO VARZIN}

(CONCLUDED)

W

HEN I was at Varzin a current of conciliation, or, perhaps I ought to say, of concession all round had set in in high political quarters under Count Caprivi. This called forth Bismarck's stern disapproval. Not that he objected to conciliation on principle: few statesmen have ever had such conciliatory feats to their credit as he; but he disapproved of the particular cases in point. $\mathrm{He}$ doubted whether they were such as could be effectively met by conciliation in the form of concessions. There had been the "climb down" before the Socialists; the Commercial Treaty with Austria ; a continually recurrent, restless endeavour to soothe French susceptibilities in various ways; and, perhaps most serious of all, a tampering with Polish affairs, showing itself outwardly by attempts to disarm Polish parliamentary opposition by demonstrative amiability to some of its leaders. If ambition be the infirmity of great minds, a belief in our own personal irresistibility is the misfortune of those of lesser calibre. Bismarck thought that such a belief was at the bottom of every one of 
the above new departures, and that every one of them was foredoomed to failure. $\mathrm{He}$ considered the Commercial Treaty with Austria an uncalledfor and unnecessary concession, which would not produce the slightest gratitude or goodwill on the part of the Austrians. Its effects would only further impoverish German agriculturists and take away 50,000,000 marks annually from the Imperial Exchequer without benefiting anybody but a few Hungarian corn dealers. The whole affair, he thought, had originated in a promise which the Emperor of Austria had probably exacted from the German Emperor in the course of the latter's visit at the Austrian manœuvres in the previous year (1890). The Emperor of Austria was naturally alert in looking after the interests of his people; also he was quite right in doing so, but that was no reason for giving German interests away for nothing. That the negotiations had been carried on at Vienna instead of in Berlin was also a point which ought to have been avoided. "I do not believe in identifying economical interests with political ones: certainly not in this case. The other party will always ask for further concessions," he said. He told me that he had always endeavoured to keep political agreements separate from those of a commercial nature. The favourable influence of the latter upon the former was problematical, whereas disappointment of commercial expectations once raised might react unfavourably upon existing political conditions. 
According to Bismarck, the whole idea underlying this Austrian Commercial Treaty was wrong. Mutual trading is in no way essential to friendship, and nothing is more certain to destroy friendship between nations than an attempt to compel mutual trading in defiance of pecuniary interest.

With regard to the French: so long as France does not accept the spirit as well as the letter of the Frankfort Treaty-which she does not as long as she encourages the periodical demonstrations on the Place de la Concorde, in sympathy with the lost towns of Metz and Strassburg-so long will every attempt on the part of Germany towards conciliation be premature and futile. For all that there is no need to show any irritability towards the French; on the contrary, it is policy to maintain the utmost correctness and courtesy in all dealings with them as with everybody else. But the French will never look upon restless attempts to gain them over as anything but as signs of weakness. Thirty years of a Chinese wall between the two frontiers, although not desirable, would be better than that.

It is a matter of history that Prussia's attitude towards Russia on two important occasions, that of the Crimean War and of the Polish Rebellion in I 863, largely facilitated Bismarck's plans for Prussia's hegemony in Germany. He looked upon the pressure which the Western Powers had sought to put upon Prussia on both these occasions as an impertinence; and down to the last days of his life was particularly anxious that Germany should never 
be made a cat's-paw to further the interests of others by opposing those of Russia. The results of the Congress of Berlin had strengthened his anxiety to avoid future entanglements. For he believed that on that occasion he had rendered good service all around in the interests of peace, and had received nothing but ingratitude in return. This attitude was in harmony with Bismarck's personal liking for many Russian characteristics; but it was of course only dictated by what he held to be Germany's paramount interests, and by no means included aught of that old servility towards Russia, which had done mischief to Germany in the days of the Emperor Nicholas, and even before then. In other words, Bismarck was not so much in love with Russia as Queen Victoria believed him to be. His partiality for England was at one time perhaps stronger than his leaning towards Russia. Still, he could hold his own energetically when circumstances called upon him to do so, either against the one or the other. But he did not believe that circumstances need ever arise-even with a growing friendship between France and Russia, that would call upon Germany to quarrel with Russia-or with England either, for that matter.

Bismarck considered the Poles to be a common danger which unites Russia and Germany; now more than ever, since the emancipation of such small nationalities as Servia and Bulgaria has given the Poles fresh hope that they, being many times more 
numerous, * might also look forward to reassertion of independence. The Poles are priest-ridden, and have proved incapable of forming a stable government by themselves. They are far better off under the dominion of Russia, Prussia, and Austria than they were under their own rule. Withal they are so talented a race that even in their present dependent position the Poles hold some of the most influential posts in Russia, in Austria, and latterly even in Prussia. Their being fervent Roman Catholics adds fuel to their antagonism to Prussia. Bismarck well remembered the time when every Continental capital had its colony of Polish adventurers of the Waschlapsli and Crapulinski order. They were an essentially disorderly, dissolute crew, always intensely antiGerman. Any false move on the part of Prussia in Polish affairs would be sure to react unfavourably to German interests in Austria and Russia, both of which countries would be only too ready to take advantage of any Prussian embarrassment.

Bismarck spoke to me of his stay at St. Petersburg, the patriarchal family life of the Russian Imperial family, and more particularly of the widow of the Emperor Nicholas, with whom he had been a great favourite. I touched upon the different position Germany occupied now when compared to those days in which the Emperor Nicholas was almost a German potentate. I asked Prince Bis-

* There are about thirteen millions of Poles living under the sceptres of Russia, Prussia, and Austria. 
marck whether he thought that it was Russia's interest to have allowed Germany to become so powerful. I do not recall the exact answer he gave. It was probably of an evasive nature; but he went on to say that it might be a critical time for Europe if Russia should produce a strong statesman, who, in pursuing a given bold policy, would not shrink from sacrificing the lives of a few hundred thousand or even a million of men. He said, "Russia is not moved by sentiment; she is guided solely by what she believes to be her paramount interest, which fortunately is peace. Thus decorative journeys, toasts, and talk do not go for much with Russian politicians." In order to be in touch with the trend of Russian affairs, it is necessary to know well what type of man exercises for the moment a dominant influence with the Tzar. Some time prior to the outbreak of the Russo-Turkish War in 1877 he himself had been in doubt as to which way things were tending. But as soon as he discovered that a certain-I think he said, a Count Peter Adlerburg, was in the confidence of the Tzar he was able to form a correct estimate of the situation. The Emperor Alexander the Second was strongly attached to old William, and more or less open to Western ideas, besides being, au fond, a soft nature. Alexander the Third had an exaggerated notion of Russian dignity, and was more difficult to deal with than his father. At one of the meetings which took place between the three Emperors of Germany, Russia, and Austria, 
during the lifetime of his father, the Grand Duke Alexander rode up to a group of German notabilities and called out in French, "Où' est l'Empereur?" "Quel Empereur, Altesse Imperiale?" was naturally the query in return. "Mon père," replied the future Emperor. It had not occurred to him that anybody else could be in question. Alexander the Third had the understanding of a peasant-no detriment in Bismarck's eyes-and was primarily open to those aspects of a question which might present themselves to a peasant. His word, however, could be implicitly relied upon, and he had given Bismarck repeated proofs that he trusted his word in return. This confidence of the Tzar the Prince held to be a valuable asset which was being recklessly squandered by Count Caprivi. He preferred the Emperor of Russia's goodwill in favour of peace as a political asset to the rudderless humour of any irresponsible Press. I asked Bismarck whether he thought that the Russians had intentions towards "paramountcy" in the direction of Constantinople. "Certainly," he replied. "It is only natural that they should wish to get the key of the Black Sea* into their hands and make it a Russian lake."

I rejoined that this might mean pushing the Turks back into Asia.

"That does not follow," he replied. "It would

* When I was in Constantinople (1896) and there was a rumour that it was intended to send a British fleet to the Bosphorus, the Russian Ambassador declared that Russia would never give up the "key to her house." 
suffice for Russian purposes that they should obtain permission from the Sultan to build a fort on the Dardanelles below Constantinople."

"But surely the Sultan would never agree to that?"

"Why not? It might even be a good stroke of business for him. It depends upon the conditions he would make."

"But how would the other Powers stand towards such an issue?"

"Well, when the time comes, the Russians might ask the German Emperor whether Germany would have any objection. If Germany should object, the objection would be probably of a platonic nature. The Russians would then ask Austria to take a hand in the game-meaning, among other things, a foothold at Salonica."

"But surely such a development would be prejudicial to England?"

"Not necessarily. It would all depend upon whether England would spoil her game by precipitation or by ill-considered action."

During my stay at Varzin I tried to find out what Prince Bismarck thought of some of the eminent men he had associated with. I had come from a country in which popular sentiment is apt to revel in superlatives, such as "the greatest man of his age," "the greatest man the world has ever seen," "the hundred best books," "the most efficacious pill," "the matchless soap," "the most nutritious food," and so forth. There is undoubtedly a 
fascination for some minds in this rough-and-ready method of scheduling things, and I was eager to benefit by the opportunity to ascertain Prince Bismarck's table of German "values"-to add his estimate, his price list of men to my stock-in-trade.

In one of our drives I happened to mention the name of "Moltke," and was somewhat taken aback to hear the Prince dilate on the great strategist's "amiability"! He said that Moltke was a colleague on whom the utmost reliance could be placed, and with whom it was a pleasure to work. By expressing himself in this way Bismarck led me to conjecture that another in Moltke's place would have played his part equally well; at least I inferred as much. So I asked him whether he had expected the military results produced by Moltke, notably in I866. Bismarck replied deliberately in the affirmative; that the efficiency of the Prussian Army and Moltke's fitness for supreme command were well known to the King, to Count Roon, and to himself, whereas the inefficiency of the Austrians was equally well known to the best men of the Prussian General Staff.

In the course of further conversation I discovered that Bismarck looked upon the Prussian Army as a school for conduct and hard work rather than as a forcing ground for heroes of the Homeric order. His faith in the efficiency of the Army as a whole was such as to diminish the prominent value of the unit or of any given number of units. Efficient fulfilment of duty did not call for any 
surprise or extravagant encomium. It was the reverse which would have caused surprise. Even a Moltke had only done what he was expected to do, and which, in all probability, another would have done in his place. Moltke and one or two others received a money grant after 1870 , it is true, but it was more on account of their having been as poor as church mice than as if their services could be rewarded by money. Cash rewards, or even unusually rapid promotion, are not the incentives to Prussian military efficiency. Promotion during the greatest war of recent times (1870) was not much more rapid than usual. Such a thing as an officer being promoted in the course of a campaign from major to major-general, let alone to lieutenantgeneral, did not take place in one single instance throughout the German Army in I870-I. All this explained to me Bismarck's platonic tone in referring to Moltke.

I was naturally anxious to find in what light Bismarck looked at his own achievements, and these are the conclusions I came to. If his work stood out in exceptional prominence, it was not so much that abnormal aptitude or merit were his, but rather that the circumstances of the case were exceptional. Prussian politicians and even Prussian royalty did not represent such a high average of efficiency when Prince Bismarck began his career as, for instance, did the Prussian Army. The record of the latter, since Jena, had been free from defeat. The best intellect and some of the noblest 
and most unselfish men of the country had worked silently-these men were curiously silent-in peace for several generations to prepare Prussia for war. On the other hand, Prussian royalty and diplomacy had met with various humiliations, and had finally led Prussia to Olmuitz.* Against such a background of failure Bismarck's achievements stood out indeed. He was certainly conscious of what he had achieved, but to listen to him was to gain the impression that he ascribed his success as a statesman not to the work of genius, but to the force of circumstances, to that common sense which is so fittingly illustrated by the story of the egg of Columbus more than to adroitness; to the fact that he saw at least with one eye when others were blind, or stupid, or wrong-headed. $\mathrm{He}$ was not at all impressed by his calling as a politician, and was far more proud of his status as a Prussian officer than of that of a Minister of State-a pride he shared with his royal master. It was not that he saw anything peculiarly heroic in the military callinghis mind did not dwell upon such a secondary consideration. He liked to be identified with the standard of conduct which prevails among the officers of the Prussian Army-the ethics of the officers' corps which forbids things with which he might have to soil his hands as a diplomatist. He hoped for indemnity as a Prussian officer for what he might have sinned as a diplomatist. But it was

* Serious diplomatic humiliation of Prussia by Austria under Prince Schwarzenberg at Olmütz, in Moravia, in November, 1850. 
only the Prussian Army which was his prototype. Bismarck told me that the instincts of the Prussian officer were supreme in King William.

Even at the apogee of his career Bismarck's mind would readily revert for a comparison to that which is "impossible," a significant difference in him and Napoleon, for whom the word "impossible" is said not to have existed. Hence Bismarck's favourite sayings - " that you cannot regulate a current, much less attempt to go against it, that at most you may succeed in steering carefully with it"; "that the position of a Foreign Minister is, at the best of times, the precarious one of a tightrope dancer." In the midst of his greatest successes he had never ceased to emphasise the limited nature of the achievable, hence another of his favourite sayings-"Qui trop embrasse mal étreint." Victorious in three wars, he was anxious not to risk the bones of a Pomeranian Grenadier in an avoidable fourth war. So free was he from that perilous affection of the Cæsars-la maladie des grandeurs-that, although he had only known successful warfare, he was most anxious that his country should never engage in another upon which their whole heart was not concentrated. For then he feared they might come off second best. This great student of national character felt that the Prussians might perhaps be trusted to "go ahead" in almost any cause they were ordered to fight for, whether it appealed to their sympathies or not-witness 1866. But he was not so sure of the other Germans. 
Therefore he was only for risking the ultima ratio regum when the case was of such undoubted righteousness as to call forth the full force of that furor Teutonicus which history had shown to be well-nigh irresistible.

Bismarck thought of himself as having been in his younger days a stout rope which could be relied upon to stand any strain: grit, reliability, that was the proud boast of a naïve, unboastful nature: "Pflicht-treue." Latterly he used to compare himself to a tough old horse that plodded on dutifully in the shafts till it dropped. His grievance was that he had not been permitted to do so. If there was one thing he loathed and detested, it was every form of exaggeration in speech or thought-more particularly the superlative form.

In one of our drives the conversation turned upon Lord Rosebery, who was a great friend of Count Herbert Bismarck, and whom I had recently got to know through him. Bismarck said he did not believe that Lord Rosebery could have many ideas in common with Mr. Gladstone. That as far as foreign politics were concerned, he thought Lord Rosebery was a totally different stamp of man with different ideas. Bismarck continued that "in the eighties" (I think he said I 885) wrangling between England and Germany over colonial matters had gone far enough and too far to be profitable, so he sent his son Herbert over to bring matters to an amicable settlement. The feeling in London at the time was one of ill-humour; and little was to be 
expected in the way of advances from Mr. Gladstone or Lord Granville. On that occasion Lord Rosebery showed himself to be a man of decision. He invited Count Herbert to stay at his house. This helped to break the ice, as far as the personal element was concerned. It also undoubtedly facilitated the negotiations which ultimately led to a satisfactory understanding. Bismarck denied the imputation that he had ever been swayed by a desire to create difficulties for England. He told me that he had always preferred a cordial understanding with England to any possible advantage which might have been gained by opposing England. But the English Cabinet were never willing to act up to the do ut des principle; the English were so suspicious of German colonial designs. He told me that a prominent member of the English Liberal Cabinet had on one occasion openly admitted to his son Herbert that Germany might have easily raised considerable difficulties for England in Egypt and had intentionally refrained from doing so. The exact expression used by the English statesman to Count Herbert was: "Your father might have upset our apple-cart in Egypt if he had liked, and we ought to be grateful to him." Bismarck considered, and openly said, that England was doing a great civilising work in Egypt.

In further course of conversation Bismarck touched upon Germany's sacrifices to England in Africa against the cession of Heligoland by England to Germany, an arrangement which came 
in for his criticism. He said that he would never have entertained it ; that what Germany had ceded to England in East Africa was a valuable assether position at Zanzibar. This she had gradually obtained by her commercial ability-honest work which was the only source of permanent benefit. As for Heligoland, which Germany had taken in exchange, he considered its possession by Germany to be not only valueless, but an incubus. The place was too unimportant to have even a sentimental significance; whereas from a practical point of view its ownership imposed upon Germany the necessity of defending it. Heligoland was not worth defending, and yet to put it into a defensive state would cost a great deal. As long as it was in the hands of the English it was for practical purposes cut off from being a coaling-station of any other Power. The fact of Heligoland belonging to England in 1870 was one of the main reasons why the operations of the French fleet during that war were so ineffective. The French were repeatedly obliged to return to a French harbour to coal; whereas if they had been able to take Heligoland they could have turned it into a coaling-station. He believed it to be impossible to put Heligoland into such a state of defence as would render it defensible in war time.

Referring to German colonial ambition, I said that I often read in German papers about Germany's need for new transoceanic markets, but I never had read a word concerning the enormous 
market Germany already possesses in free-trade England, trading also as she does, on equal terms with England, in British colonies. If these colonies belonged to Russia or France, or in fact to any other nation, the German trader would be immediately more or less cut off from them. The industrial rise of Germany could never have become what it is unless English markets had been open to German goods. Though now, it is only fair to state that Germany is in return becoming more and more a valuable market for English goods.

Prince Bismarck did not gainsay this, but replied that he had never been a so-called colonial enthusiast. He had given ample proof in Africa of his desire to limit German colonial expansion to what Germany could swallow. His ideas with regard to German colonisation were regulated by what were the requirements of the case. I understood him to mean that he did not think it was to Germany's advantage to strive to hurt England. England's colonial power is a natural growth which could not be artificially imitated by Germany overnight. If Germany is destined to rival England over sea, he thought she would only be able to do so by a gradual development along similar lines to those which England had so successfully pursued. He did not believe in the efficacy of a sudden Weltpolitik, nor in the salvational properties of such a consummation, even if it were feasible. Mere wealth is not everything, and, besides, he knew that England's so-called "world policy" had not yet 
placed a fowl in the Sunday cooking-pot of every individual Englishman. For all that he was for encouraging every normal, consequently healthy, colonial expansion, and although it would never pay Germany to quarrel with England, there was no need to put up with unprovoked slights from her. If a man happens to live in a bigger house than you, that is no reason why you should allow him to treat you with unprovoked contumely.

He next spoke of Major von Wissmann, who had recently been superseded in East Africa. Bismarck held a very high opinion of him, and considered his supersession to be a blunder, as well as a personal injustice. He told me that Wissmann had come to him for instructions prior to starting to take up his appointment in Africa. " "I cannot give you any instructions,' I told him. 'I feel sure you will do what is right and proper, and when you are in doubt you need only remember that you are a Prussian officer in order to find the key to the situation.' " I thereupon asked the Prince whether he had had any exceptional previous record of Wissmann to go upon to enable him to place such implicit trust in his capacity. He replied that such was not the case; that his high opinion of Wissmann had been largely a matter of intuition.

I asked Bismarck whether he had ever said, that South Africa might yet be the scene of a life-anddeath struggle of the British Empire. He replied that he did not remember having said so, but he might have thought it. 
Court intrigue was one of the staple causes of his sleeplessness during those years which to the ken of the outer world marked the summit of his power. The case of Count Harry Arnim was probably the "ugliest" of these items. I had once met Arnim's bosom friend, Legationsrath von Loë, in Paris, where he was living in 1889 , married to a French marquise. He gave me to understand that he was the author of the notorious pamphlet, entitled Pro nihilo, commonly attributed to Count Arnim, and this I mentioned. Bismarck replied, that von Loë was a madman; that it was not so much Arnim, who was a tête montée, as those behind him that had been the bane of his existence at the time. I added that many people in England had never been able to see a justification for those among his own countrymen who had accused him (Prince Bismarck) of having been actuated by a feeling of personal rancour, let alone of having strained the legal powers at his disposal in order to ensure Arnim's conviction and severe sentence. And I cited, as confirmation of this, the fact that the Times, although never very friendly towards the Prince, had declared in a leading article at the time of Arnim's trial that the latter's conduct had obviously been of a kind which no English Minister would tolerate for a moment; for it would make official discipline illusory. Bismarck said that Arnim had only himself to thank for the course things took-that his sentence was far more severe than he (Bismarck) had expected, or would have 
wished, and that he had been sincerely sorry for Arnim's tragic fate. As for the legal tribunals of Germany, the case of Geffcken, in which the latter, although richly deserving of punishment, had been acquitted, furnished sufficient proof of their independence were any needed.

Concerning the more harmless incidents of German Court life Bismarck related the following :-

"It was occasionally one of my functions to present all sorts of people to the King, and it now and then happened that my head was so full of more important matters that the very name of the person I was about to present lapsed from my memory. When that was the case I used to put a bold face upon it, and there being no time to inquire after names, I bluntly presented a man I did not know as Count Solms. You see, there are so many Count Solms that the King could not possibly know them all by sight. On the other hand, a man whose name might be Müller or Schulze was not likely to take it very much amiss if he were presented as Count Solms, which, after all, is a good family name. I got out of my difficulty in this manner on more than one occasion, and it never failed."

Bismarck told me that foreigners of both sexes manage to push their way into the different German Courts, who he felt sure could not possibly be tolerated in good society in their own country.

During my stay at Varzin I was struck by Bismarck's lack of interest in individuals-his dis- 
passionate attitude towards events even of great importance, and apparent indifference with regard to his own share in them. He seemed to have no feeling of satisfaction connected with their memory. His perfect freedom from every sensitiveness in discussing subjects which must have been fraught with painful memories to him was truly remarkable. He had been so long accustomed to deal, and that successfully, with questions involving tremendous issues that incidents and persons connected with them-a reference to which the outsider might have expected to be most annoying or at least exciting-scarcely interested or even affected him at all. In this category were the principal personages of many causes celèbres, the source of great excitement at the time. To Bismarck they were nothing more than flies on a wheel-only flies. For habit had led him to a cold and unerring, even a fierce appreciation of values. A reference to Count Beust, a man who must have caused him a goodly number of sleepless nights, was of a kindly, platonic nature. I happened to mention that I had known Beust, when Bismarck said that he was one of the most amiable of mena thorough Saxon; his cardinal weakness was vanity. That at Gastein, where they had once been together for some days (187I), Beust kept a pile of his own musical compositions on the drawing-room table, and used to distribute them to his visitors.

Bismarck was a great admirer of Thomas 
Carlyle, who reciprocated the sentiment, and had extolled Bismarck as that "monster of industry." When Carlyle was elected a knight of the civil section of the Order Pour le Mérite, Bismarck wrote him an autograph letter, which is now among the relics in Carlyle's old house in Chelsea. Bismarck did not, however, associate himself with the bestowal of the Order upon a German resident in England-Professor Max Müller. Bismarck had a poor opinion of him as one of those professors who dabbled in politics, and were to be met with in the ante-chambers of embassies. $\mathrm{He}$ told me he regarded his learned countryman as an overrated person-what the Germans call ein Streber. But the tone in which he said it gave me the impression that Müller interested him very little one way or the other. $\mathrm{He}$ added that he understood Müller had been one of the protégés of the Prince Consort, who, he said, had been peculiarly open to the influence of the Streber type.

I had heard much of Bismarck's tempestuous passion. I had even been present when passionate utterances escaped others within his hearing, and yet measure and moderation were always the tone, as well as the purport of everything he said. This moderation and the refinement it indicated dominates my memory of Varzin. I might have taken it as a result of the soothing effects of old age, and at times I was indeed inclined to do so-or more likely still the product of the imagination of the 
visitor-the inebriating effect of flattering attention received. But I know now that it was neither. It was in the first instance the innate refinement of the man, the result of a "good nursery," the good breeding of the well-educated; and thus it must always have characterised him, as we now know by irrefragable testimony* was indeed the case. Added to this powerful influence there was a rhythmic balance of a strong mind trained by the iron discipline of a lifetime passed in battling with cataclysmic forces. It must have been the task of a Titan to bring the two extremes of a fiercely passionate temperament and an exceedingly sensitive -I might even say nervous-disposition into one harmonic whole. And yet how often had I heard of Bismarck's coarseness, his violence, his brutality, his mendacity, and, to touch upon a narrower subject, his rabid hatred of England and the English! If such perversion of the truth could obtain worldwide currency with regard to this great man, might it not contain a lesson and a warning? If thus the slander of the truly great, what value may we attach to the glowing estimates so often formed of the lesser luminaries of the day.

There was one impression in particular I carried away from Varzin concerning which there could be no manner of doubt, and that was of Bismarck's solitude-his intense melancholy. Nor could this frame of mind of his have been merely a result of

* See Correspondence of J. L. Motley. Keudell's Erinnerungen. Bismarck's Letters to his Wife; ditto to his sister, among many others. 
old age, though want of occupation and continuous brooding over the apparent ingratitude of his countrymen had doubtless intensified it. Anxiety for the future of Germany also saddened him. I remember his referring to the generous qualities of the English, as evidenced by the readiness and joy with which they recognised the eminence of the younger Pitt as being the son of his father, "a chip of the old block." $\mathrm{He}$ also recalled Pitt's last words, "Alas! my country!" or, "My poor country!" I think he said.

Bismarck had suffered from fits of depression, as is well authenticated, right through life. Melancholy is an essentially German trait of character, and may not be unconnected with the state of the stomach, as Hamlet said dreams are. In every case it is often met with in highly developed natures, a form of morose pessimism which affects them at times. Moltke, in the very midst of his triumphs in 1870 , yearned for a release from suffering - the suffering of living. The number of gifted Germans who at one time or the other have sought a violent end to their "Leiden am Leben" is sruprising. It would seem that the German temperament does not allow of that full satisfaction arising out of the mere fact of living-once the illusions of youth are gone-which is to be found in all ages and among all classes of Frenchmen and Englishmen.

Gladstone, after the most crushing political defeat, could dine out every night and enjoy the small 
talk of a dinner-table. Palmerston at nearly fourscore found pleasure in backing a horse and riding one, too, at a neck-breaking pace. Thiers was gratified by the homage of a Paris salon to the last; whereas Gortschakoff would endeavour to conjure up his youth in the company of a mistress. Bismarck, with the consciousness of having altered the map of Europe and revived the German Empire, could scarcely exist outside his own four walls.

Frenchmen may, perhaps, take it as a part of the Nemesis for Sedan that eminent Germans are above all others called upon to illustrate the truth of Chamfort's stern aphorism-“Le bonheur n'est pas chose aisée. Difficile de le trouver en nous; impossible de le trouver ailleurs." It is perhaps one of the reasons why Goethe is almost a demigod to the Germans; that his nature was so harmoniously rounded off; that, in spite of his temporary fits of despair, he was a happy man. The life of the Teuton is apparently less harmoniously set off than that of others; he is less satisfied with results achieved, whatever they may be, than other nationalities. The consciousness of success does not give him contentment. The concluding idea of the typical English novel, of a wealthy marriage and then settling down to everlasting happiness afterwards, finds little response in the Teuton. It is as if existence were not a thing complete in itself, but one fraught with a yearning for the unattainable: an endless struggle of the 
soul (das Seelische), a pining for deliverance. This element of tragedy runs like a red thread through Wagner's great music-dramas. The Iliad compared with the Nibelungen-Saga is a short and simple story. In the Nibelungen the protagonist is engulfed, as it were, by a weird, fatalistic development which does not culminate in the course of one life, but extends through several generations.

Bismarck had moments between I890-I when the idea of suicide may possibly have been present to his mind. His religious faith added to his strong sense of personal dignity probably prevented the thought obtaining complete possession of him. Lord Clive-a rare exception among great Englishmen-committed suicide. Bismarck was not without affinity to Clive in more respects than one, notably in his insensibility to the meaning of fear. 


\title{
CHAPTER VIII
}

\section{VISIT TO FRIEDRICHSRUH}

\author{
JANUARY, I 892
}

THE parting words of Prince Bismarck on the I occasion of my previous visit to Varzin had led me to conclude that whenever anything should bring me to Germany I was at liberty to go and see him. In January of the following year ( 1892$)$, whilst on a visit to Professor Lenbach in Munich, I received a letter from Count Herbert Bismarck, dated Friedrichsruh, containing the following :-

"Only a few lines to thank you for your kind letter of the day before yesterday, and to tell you that my parents would be very pleased to see you in case you should be inclined to return to England viâ Friedrichsruh. If this is agreeable to you, I would endeavour to arrange to come here for a couple of days."

One morning Prince Ludwig of Bavaria came into Lenbach's atelier unannounced, accompanied by two of his daughters. After glancing round at the various oil paintings and sketches which covered easel, wall, and floor, his visitor turned the conversation on Prince Bismarck, for whom the heir to the Bavarian throne expressed profound regard 
as well as anxiety about his health and wellbeing. He asked Lenbach what news he had from Friedrichsruh. Lenbach took him confidentially aside, and told him that Prince Bismarck had expressed himself in terms of warm appreciation concerning some speech on public affairs which Prince Ludwig had recently delivered and which had called forth wide comment in the German Press. This visibly pleased the Prince, and H.R.H. being informed that I was about to start for Friedrichsruh, asked me to convey his best remembrances to Prince Bismarck.

I arrived at Friedrichsruh in the forenoon of the I 9 th January, and was shown into my room, where, shortly afterwards, Prince Bismarck, who had just come in from his morning walk, joined me. After bidding me welcome, he sat down on the sofa with his hands resting on his stick.

It was a cold day; the snow was on the ground, and the Prince wore a pair of reddish-brown, unvarnished Russian leather top-boots, which, he told me, had all the virtues of real Russian leather. He said they were only to be had from a bootmaker in Weimar, who had learnt the secret of their watertight preparation as practised in Russia. In consequence of the connection between the Court of Weimar and the Russian imperial family, a number of distinguished Russians were in the habit of coming to the little Saxon town, and they wanted waterproof boots. They would have nothing but the real Russian leather. 
Suddenly Prince Bismarck reverted to Shakespeare.

"You remember those lines in Hamlet: "He slew the sledded Polack on the ice'? Now can you tell me whether Shakespeare meant the word 'sledded' to convey the idea that the Polack was armed with a sledge-hammer, or that he was simply driving in a sleigh ?"

I was bound to confess that although I had repeatedly read Hamlet both in English and in German, I had no distinct recollection of the passage in question. I promised Prince Bismarck, however, to consult one of the best English authorities on the subject on my return home, and to let him know the result. This I subsequently did.

On this, as on a previous occasion, Bismarck referred to the controversy concerning the authorship of Shakespeare's plays. He gave expression to a half-hearted belief that there might well be something in the supposition that Lord Bacon and not Shakespeare had written them. "Well, well," he said, with one of his significant looks implying doubt or at least an open mind on the subject, "after all, there may be something in it." $\mathrm{He}$ did not pretend to any special knowledge, but he said that he could not understand how it were possible that a man, however gifted with the intuition of genius, could have written what was attributed to Shakespeare, unless he had been in touch with the great affairs of State, behind the scenes of political life, and also intimate with all the social courtesies 
and refinements of thought, which, in Shakespeare's time, were only to be met with in the highest circles. It also seemed to Prince Bismarck incredible that a man who had written the greatest dramas in the world's literature could, of his own freewill, whilst still in the prime of life, have retired to such a place as Stratford-on-Avon and lived for years cut off from intellectual society and out of touch with the world. On the other hand, the idea that the authorship of Shakespeare's plays was to be found hidden in a secret cypher struck him as absurd.

On going down to the drawing-room, where the members of the family and the guests were already assembled, I was introduced to a spare, stooping, morose-looking little man, standing in a corner with his hands behind his back, dressed in a badly fitting pepper-and-salt suit. This was the renowned Privy Councillor of Legation, Lothar Bucher, of whom I had heard so much, and of whose thoughtful writings I had read almost all, without being able to form an adequate idea of his personality. I knew, however, that he had been one of the most able and faithful of Prince Bismarck's assistants in the Wilhelm Strasse for over twenty years, that he had been twice sent on a secret mission to Spain prior to the war of 1870 , his estimate of the situation being apparently held of higher import than that of the accredited Prussian ambassador. Bismarck was supposed to attach great value to Bucher's judgment; consequently the latter's in- 
fluence on the course of affairs was believed to have been out of all proportion to his position, influential as it was. He had retired from active service some years before, and had now come on one of his periodical visits to his former chief-long since his personal friend. Insignificant as he was in stature, I thought of the old battleship, the Témeraire, lying at her last moorings-when I met this old man by the side of his fallen chiefto whom he clung faithfully until death.

I remembered an instance of Bismarck's delicate consideration for Lothar Bucher. In the course of my stay in Varzin I had expressed a wish to make Bucher's acquaintance. The Prince said I should probably find him in Berlin on my way back to England, and continued, "I would gladly give you an introduction to him; and, moreover, I feel sure that he would be pleased to make your acquaintance, but his health is not good, and he might not be in a humour to see anybody. In such a case he would probably still receive you out of consideration for me, and I should not like to place my old friend before an irksome alternative."

Some years previously I had met a Saxon colonel of the name of Bucher in Dresden, who claimed kinship with the famous confidant of the German Chancellor. He had assured me that the name of Bucher had originally been "Boucher," and that the family was of Huguenot origin. This remark came back to me as I found myself opposite him at Prince Bismarck's table. I fancied I saw a strong 
likeness to Cardinal Richelieu in the plainly dressed little man, with the thin, grey moustaches $a$ la Henri Quatre, and the finely chiselled featuresalready in their yellowish tint betraying ill-health, if not physical suffering-who sat silently absorbed in thought before me!

There was something decidedly French in Bucher's appearance, but not of the familiar modern French type. He reminded me of those esprits fins-ricaneurs, frondeurs-nurtured on Montaigne, Montesquieu, Diderot, and Voltaire, who in days gone by were to be met in a French drawingroom or among the suite of a grand seigneur, such as those with whom Frederick the Great delighted to engage in mental sword-play at Sans-Souci.

There was little courtliness in Bucher's appearance, unless the dignity of silent reserve be accounted a courtly adjunct. Stripped of his badly cut coat and clad in velvet and frills, slight as he was, he would have looked the French seigneur of a sceptical, philosophising age. A sword would have become him, too-even one with a jewelled hilt. His was a scintillating mind, and his pen had the temper we associate with the steel of Toledo. He possessed besides one of the highest qualities - that of the scholar, the unselfish courage of conviction; unselfish even when his ideas were not without a touch of venom. The two ugly weeds which thrive in the shadow of the great-servility and arrogance-had not poisoned this little man - at most he was soured 
by a contempt for mankind in general. In his position so near the all-powerful Minister he had seen a deal of the meanness of human nature. Bucher was one of the few whom close contact with Prince Bismarck had not affected with megalomania, and his deference was free from every taint of servility. But his interests were not limited to this world, for in his leisure hours he cultivated an antidote to mundane vanities: he was a deep student of astronomy.

Bucher's personality and his possible French origin were of more than casual interest; they helped to explain much about the man. Amongst other things, his intimacy with Ferdinand Lassalle, the Socialist, had been a source of astonishment. Lassalle had appointed Bucher his executor, and that he should have done so was explained by the mutual attraction which existed between two diametrically opposite, and yet not necessarily antagonistic, natures. Lassalle, the boastful, brilliant egotist, must have felt impressed, if not attracted, by Bucher's self-contained, taciturn temperament. On the other hand, the latter harboured a kindly feeling towards one whose aggressive originality was as much calculated to interest as to amuse him. It was the case of a sensualist face to face with an ascetic. Bucher's French origin also helped to explain the clarity, the luminous sarcasm of those "Letters from Abroad"* which he contributed in the "fifties" from England and elsewhere to the

* Bilder aus der Fremde. Berlin, 1862. 
Berlin Nationalzeitung. But, above all, it accounted for his logical analysis of the working of parliamentary institutions-their curious anomalies and inconsistencies-to be found in his interesting book on that subject.*

Bucher sat next to Princess Bismarck at lunch, and it was evident that he was not merely an habitue, but an honoured guest of the family. $\mathrm{He}$ seemed wrapped in thought, and never spoke unless spoken to. There was a touch of deference mingled with the tone of kind familiarity with which Princess Bismarck spoke to her "Büchlein." For he was one of the staunch and true, whose encyclopædic knowledge was a mine of wealth upon which to draw whenever any subject came up needing elucidation. When the newspapers were brought in Prince Bismarck handed "Büchlein" a paper, and drew his attention to some paragraph, with regard to which they exchanged a significant glance and a few words of comment in an undertone. As usual, towards the end of lunch the butler handed Count Herbert a list of special wines, from which a bottle was selected as a bonne-bouche for dessert by the vote of those present. "Büchlein" was also consulted, and the wine he voted for on this occasion was the one chosen. It was an excellent choice.

After lunch Prince Bismarck asked me if I would take a sleigh drive with him, whilst Professor

* Der Parliamentarismus Wie Er Ist. Lothar Bucher. Carl Crabbe, Stuttgart, I88I. 
ANXIE'TY FOR HIS WIFE'S HEAL'TH I4I

Schweninger accompanied Princess Bismarck in another sleigh, and Bucher went back to his books. The Saxon Forest in the midst of winter is a beautiful sight. Snow lay upon the ground several inches deep; it hung heavily from the branches of trees and thickets, whilst the hoar frost had covered everything as with glittering diamonds. Prince Bismarck told me to look out for the wild boar as we drove near their feeding-place, but none were to be seen. The tinkling of the sleigh bells had doubtless driven them away.

Bismarck was not in his usual good spirits. $\mathrm{He}$ said that Schweninger was anxious about the health of his wife, that she was one of those who kept up her spirits to the last, but she was far from well. $\mathrm{He}$ then repeated what he had told me in Varzin: "If she is to go, I do not wish to remain behind."

Apropos of Lothar Bucher, Bismarck said he was a very able man, with a proud consciousness of his own value, and above all a gentleman; that Bucher's career had not been as brilliant as he (the Prince) would have liked it to have been; but he had never been able to get the Emperor to forgive him for having been among those who had refused to pay taxes in 1848-an unpardonable offence in the eyes of His Majesty.

Bismarck's thoughts turned towards Russia and his experiences in that country. He had a strong liking for the Russian national character. In his opinion, the conditions of life in Russia-notwith- 
standing all we hear of political despotism-are of a nature to mould character on broader lines than is the case in some countries. Russians are not petty in their likes and dislikes. If they are noble-minded, they are so to a superlative degree. They possess a high standard of altruism, and if they are vicious there is something impressive in the uncompromising nature of their vice. In other words, for good or for evil, they stake their whole personality more readily and more fully than we do.* Many Russians of both sexes, of high station, have at all times voluntarily devoted their lives to the service of their humbler fellowcreatures in a manner quite unknown in any other country outside of religious orders. Bismarck had a warm corner in his heart for the Russian peasants as a class, and said that he respected them, that they had the instincts of gentlemen. At dinner we were the same party as at lunch, with the addition of Baroness Merck, whose husband, engaged in Hamburg during the day, joined the family circle later in the evening. Baroness Merck, who has since died in the prime of life, was a charming woman and a great favourite, both with

* The late Lord Dufferin, who, as ambassador at St. Petersburg, had ample opportunities of studying the Russian people, would seem to have held very similar views to those of Bismarck with regard to the Russians, as evidenced by the following: "Take them altogether, there are no nicer people than the Russians. They have the defects of their qualities, but take them all in all, there are no foreigners whom I found more faithful and more agreeable friends. They are sometimes a little slow in admitting you to their confidence, but once they trust you they trust you for life." 
Prince and Princess Bismarck. The Mercks owned a very pretty country-house about half an hour's walk from Friedrichsruh, and Princess Bismarck often drove over to visit her in the afternoon. The Princess used to call her the "good fairy of the Saxon Forest," for her sympathetic presence with her quiet, undemonstrative manners brought cheerfulness in its train. If Princess Bismarck wished to show a guest a signal mark of her favour, she would playfully lead him to believe that she intended to ask Baroness Merck to dinner expressly for his benefit. The Prince always made a point of taking her in to dinner, and allotted her the place of honour by his side. Baroness Merck was the one visitor to the house with whom Bucher was on terms of friendship. For, besides being a happy wife and mother and a very attractive woman, she took a keen interest in intellectual pursuits. Bucher had been her mentor in the study of astronomy, for which, as I was informed, she showed marked ability. He once referred to her in English as the "charming wood-elf."

Lenbach had given me a sketch he had made of me during my stay in Munich, and requested me to show it to Prince Bismarck. This I did in the course of the evening. He looked at it, and turning to me with a peculiar twinkle in his eyes, he said, "He has flattered you."

Princess Bismarck suffered from sleeplessness and usually remained up till everybody else had 
gone to bed, sometimes until the small hours of the morning.

"What is the use of my going to bed? I cannot sleep," she said. In former days she had been a devotee of the piano; but I never heard her play. Latterly she preferred to listen to others. Mascagni's Cavalleria Rusticana had just become popular, and she never grew tired of listening to selections from it. "Whitmännchen, play me once more the Cavalleria Rusticana" she would often say. Those who found grace in her eyes were uniformly called by a diminutive appellation. Bucher became "Büchlein," as above.

The piano stood in a room leading from the drawing-room. As long as Prince Bismarck had not gone to bed I used to avoid playing, or at most touched the keys gently for fear of disturbing him, for I understood that he did not care for the piano. However, on the present occasion, Countess Rantzau called me into the other room and asked me to play something to please her father. She brought me a book of popular melodies, among which were three well-known Russian songs; although they have for long formed part of every German popular Liederbuch. They were "Der Rothe Sarafan," "Seht die Drei Rosse Vor Dem Wagen," and "Schöne Minka." All three are peculiarly homely and sad in spirit. I played them off at sight. When I went back into the drawing-room Prince Bismarck looked up from his paper and said that there was something about 
those songs which appealed to him; that such was the kind of music he liked.

I was anxious to have a private talk with Bucher, although well aware that he was like an oyster, which neither the knife of flattery nor the wedge of amiability would be likely to open. However, as German social etiquette-herein unlike that of some countries-considers an advance which one visitor in the same house makes towards another to be a mark of courtesy, to be reciprocated de rigueur, I determined to risk it.

Bucher occupied a room on the first floor, nearly opposite my own. So next morning after breakfast I rang the bell, and asked the servant to present my compliments to the Herr Geheimrath and to ask whether I might be allowed to pay him my respects.

Bucher's room was a very large one. It was like my own, bedroom and sitting-room combined, a screen being. placed in front of the bed. A number of books were lying on tables, or stacked on shelves, mostly with paper slips protruding from the edges.

He spoke to me as to one whom he could trust; a somewhat unusual occurrence with him, as I had always been given to understand. I asked him whether he could tell me anything about the Bismarck memoirs, as several London publishers, having heard of my intimacy with the Bismarck family, were continually writing to me on the subject, and that I should be glad of any informa- 
tion if it could be given without indiscretion, the more so as I did not like to ask any member of the family direct about the matter.

Bucher said that the writing of the memoirs had been a difficult task, for it was hard to prevail upon the Prince to keep on with it. He seemed to be totally devoid of that interest in the work which memoir writers usually possess to a morbid extent : the desire of saying and seeing something about themselves in print. It was necessary to appeal to him continually, and to emphasise the fact that the task was one, the accomplishment of which was a duty Bismarck owed, not only to himself, but to the German nation-to posterity. However, he was thankful to say that the book was now as good as finished; that it consisted of two distinct parts ; one to be published during Bismarck's lifetime, the other after his death. This latter statement Bucher made with a peculiar emphasis; in fact, the manner in which he referred to the second part left the impression that it must contain matter which even now (I902) has not seen the light.*

Bucher expressed himself severely concerning the ingratitude with which Bismarck had been treated. He said that the outer world was not yet

* Bucher seemed to have a peculiar disinclination to mention the name of Bismarck or even to refer to him as the Prince, which was usual with others. This was probably a habit grown upon him from the time when he was in active service at the Foreign Office; he spoke of his chief as "him" in an undertone, with deference, but without a trace of servility. 
fully aware of the extent to which the unification of Germany was due to him; that it was inconceivable to what a degree he had been constantly thwarted by those whose highest interests he was engaged in championing. This was particularly the case during the crucial period which preceded the AustroPrussian War; although he had had to battle with intrigue all his life. At times he was unable to rely on the support of a single person except the King, and not always on him. Sometimes people in quite subordinate positions were detected in endeavouring to defeat his plans. Thus, when the question of the Elbe Duchies was in its most critical stage, the intricate legal aspect of the situation necessitated the consultation of an enormous number of deeds and documents which were submitted to the law officers of the Crown. These documents were stowed away in the Government offices in the Wilhelm Strasse. On one occasion Bismarck found out that some of the minor officials entrusted with the care of these could not be relied upon, but through some outside influence tried to hamper his researches.

Bucher took a very pessimistic view of things in general, and in his quiet, methodical way expressed himself with singular frankness regarding what he held to be probable ultimate results of Prince Bismarck's dismissal.

"The dominant influence with us at present is a queer mixture of cunning and impressionability leading to rapid generalisation based upon the 
observation and knowledge of the surface of things. This in its turn leads to impulsive action. But," he added, "cause and effect in politics rarely lie close together; the consequences of an inept policy generally show themselves only after the lapse of years."

"You see," he continued, "the whole world has viewed the rise of Germany with envy. Leaving admittedly inimical foreign nations out of consideration, the power of the Roman Catholic priesthood, for instance, will at least for a long time to come be a thorn in the side of Prussia, all the more dangerous since it has so strong a hold internally within our own country. These difficult conditions will ever make Germany's political position a precarious one; demanding at all times very able statesmanship to maintain it unimpaired. The true significance of the consequences of "his premature retirement will only come home to the country when he is dead. The mistakes already made (1892) are incalculable, hardly to be retrieved."

Our conversation then turned to other subjects, notably to Mr. Gladstone. I was well aware from Bucher's writings that he was imbued with a great dislike for Cobden's free trade gospel and also more especially for Mr. Gladstone. Yet I was surprised at the virulence of his animosity towards the latter, even although certain sections of English feeling with regard to Mr. Gladstone at that time were very bitter. Bucher was acquainted with many expressions of this sentiment-notably 
Mr. Jennings' book, * also an anonymous one published in London in $1885, \uparrow$ containing Thomas Carlyle's scathing denunciation of Gladstone. He had heard of Professor Tyndall's dictum, that in a former age Gladstone would have been righteously beheaded. But Bucher went beyond this. $\mathrm{He}$ even accused Gladstone of belonging to a "corrupt oligarchy."

Bucher, it is well known, lived in England as a refugee from $1849-55$, in which years he was a habitual student in the reading-room of the British Museum. He had made a deep study of England's social and political institutions, with which he was probably more familiar than any other German except Professor Rudolph von Gneist. But whereas Gneist was an admirer of England's political institutions, and as such was responsible for a large amount of the popularity these for a considerable time enjoyed among the German middle classes, Bucher was entirely of an opposite way of thinking. He loathed what he called "the cant of English parliamentary institutions," and wrote the book already mentioned, in which he endeavoured to show that parliamentary institutions, and more particularly those of England, were the most detestable of shams, that they have outlived their efficiency and usefulness.

* Mr. Gladstone: a Study, by L. J. Jennings, M.P. Blackwood, London and Edinburgh, 1888.

† An Apology for the Life of the Right Hon. W. E. Gladstone. Ward and Downey, London, 1885. 
The knowledge that such were Bucher's opinions only added to my interest in listening to his conversation. I had heard so many of my own countrymen express similar views regarding what they termed the "detestable military despotism" under which Germany groaned, that the other extreme view was for a moment rather refreshing. Bucher never liked England or her institutions. He always disliked us, and his naturally morose disposition added to the intensity of his dislike. This may not be evidence of a lovable nature. Still, to hate one and the same thing consistently for half a century may well be considered a feat in itselffirst stage on the road to virtue, in as far as it might indicate the goal of sincerity - in times when many recant to-day what they swore by yesterday.

Bucher, as I have already indicated, was not a "cash" nature. His dislike of our institutions was sincere, and with all its aprete-the waspishness of a morose temperament-it was the outcome of patriotism. He was convinced that the introduction of English political methods and institutions into Germany, which had long been the aim of an influential German party, would be fraught with peril to his country. During many years he was the most potent anti-English influence in the Prince's surroundings. As such Bucher must take a place among those forces which have played an important part in contemporary politics. Bismarck's ultimate attitude towards free trade and the low opinion he held of Mr. Gladstone as a statesman were, I 
fancy, at least partly due to Lothar Bucher. He prepared the soil. For although there could be no personal influence in the conventional sense of the term, Bucher's position and the very high opinion Bismarck entertained of his juridically trained intellect, the consequent trust he reposed in Bucher's judgment, could but give him at all times great weight with the Prince.

In a general way Bismarck took little interest in English affairs outside the broad lines of international politics, the less so as the England of his youthful admiration was no longer the England of his maturity. On special subjects, such as Free Trade and English home government, so long directed by Mr. Gladstone, an accurate familiarity with which could only be the result of close study, Bismarck had to take his knowledge secondhand, and he was a good listener when necessity called for the practice of Goethe's precept of letting in "Mehr Licht."

Bucher, both by his pen and his uninterrupted personal intercourse with Bismarck during long years, in continually drawing the Prince's attention to the inconsistencies of Cobden, free trade, and Mr. Gladstone may thus have well ended by influencing him in some degree. A volume of Bucher's essays* published since his death consists of sixteen articles contributed at one time or

* See Kleine Schriften von Lothar Bucher (Stuttgart, 1893), containing inter alia "Der Cobdenklub" (188I), pp. 180-219; "Aera Gladstone" (1 882), pp. 220-46. 
other to different German periodicals. Of that number nine deal exclusively with English affairs; one and all in an adverse critical spirit. There can be little doubt that Bismarck read them when they first appeared and agreed with their trend of thought. But for all that Bismarck's antipathy towards Mr. Gladstone never went as far as is generally believed. Bismarck was too much of a humourist to go the whole length with anybody as uncompromising as Bucher was on the subject of Gladstone. His sense of humour would assert itself, and instead of feeling animosity, he would end by being amused. I never knew Prince Bismarck express-nor do I believe he felt-personal dislike for $\mathrm{Mr}$. Gladstone, or go beyond a humorous assertion that he quibbled with words, and had ended by becoming their victim. Whereas it is generally understood that Mr. Gladstone's sentiments towards Prince Bismarck were not quite free from a suspicion of furor monachorum. If $\mathrm{Mr}$. Gladstone, when last in Germany (I895?), had called at Friedrichsruh, I am perfectly certain that Bismarck would have been pleased to see him, and would have received him with all that marked courtesy and distinction which he always extended to eminent political compeers. But Mr. Gladstone remained in Hamburg and sent his son Herbert and Lord Rendel instead, without first inquiring whether their visit would be agreeable. Under the circumstances this was a distinct breach of German etiquette, although, of course, unintended. In 
every case when. Mr. Gladstone's son and Lord Rendel called at Friedrichsruh they found the lord of the manor " not at home."

I only met Bucher once again. It was in Berlin, in his flat, in the month of July of the same year. He looked so ill that I stayed but a few minutes in his company, not wishing to trespass upon his good nature. He was already suffering from the complaint of which he died at Glion, in Switzerland, in the autumn.

Not a line in memory of one who had rendered his country long and faithful service appeared at his death in the Berlin official gazette. And yet his were valuable services, for he possessed the grit of the statesman, with a penetrating perception of the real nature of things. This is evidenced by the study of his writings. But even these give a very incomplete idea of the talents which-patria inserviendo consumor-Bucher devoted to the service of his chief and his country. As a working assistant of Prince Bismarck he did his best and most valuable work. Others of far less ability have availed themselves of their contact with Bismarck to advertise their names before the world; this man had been content to work during a lifetime in solitude and in proud silence. For a certain pride is the almost inevitable outcome of the disdain with which the contact with inferior natures is apt to inspire us. Bucher's only recreation used to be a couple of hours of an evening spent in the back parlour of some cozy old Berlin res- 
taurant over a pint of vin ordinaire, while he was many a time in possession of enough exclusive information to have been able by its timely utilisation to make a fortune. But to Bucher money was not everything-in fact, very little. A typical old bachelor, as long as he could afford his pint of wine the world of finance had little interest for him.

He was in his way one of the most remarkable men of his time in Germany, partly owing to the fact that his intellect was of a kind very unusual among Germans, and that his energy found its best possible outlet in the service of the State. He belonged to those rare political natures who are gifted with what has lately come to be called by a famous phrase an "intelligent anticipation of coming events." He was one of those whose acute perception, as the Germans say, "hears the grass grow."

Hardly had Bucher passed away than his memory, and in connection with it Prince Bismarck, was venomously attacked in the Press.

On my visit to Count Herbert Bismarck at Schoenhausen after Bucher's death in January, I893, a silver bowl formed a centre-piece on the dinner-table. "It is poor Bucher's wedding present to us," he said. Bucher was not the man to give such a present where he harboured enmity, as he was said to have done, nor Count Herbert Bismarck the one to speak as he did if such had been the case. 


\section{CHAPTER IX}

\section{VISIT TO FRIEDRICHSRUH}

MAY $28 \mathrm{TH}, 1892$

T $\mathrm{N}$ the month of May Count Herbert Bismarck 1 became engaged to Countess Margaret Hoyos, and in connection with his engagement I was invited to come to Friedrichsruh.

When I arrived Prince Bismarck was taking his morning walk in the grounds, where I found him sitting on one of his favourite seats under the trees. As he saw me approaching from the distance, he held up his stick and called out in English: "There, you see, I have still got your stick!" By his reply to my felicitations on the engagement of his son, I learnt that the young bride had already gained the heart of the family.

I do not recollect how it came about, but the Prince then expatiated on one of his favourite topics: the mixed character of all great political races, and more particularly the important part played by the German race in this connection. "Look at the South Germans," he said: "they have always lived at loggerheads with each other. There is 
too little alloy in their composition; each community wants to remain by itself and have its own way. Thus they never attained that political cohesion which characterises great nations. The Prussians owe some of their best political qualities to the Slavonic strain in their blood. The German are the hard, untractable male element; the Slav and the Celt provide the softer female ingredients in the composition of nations."

I looked at Prince Bismarck's characteristic features-there was something Slavonic in his cast of countenance - and thought that he himself afforded a brilliant instance in point, but I did not say so.

"The French," he continued, "owe much to their aristocracy, which is of Teutonic origin. The decline of this element is a serious matter for France. And look at England-where is there such a mixed race as the English? Why you yourself," he added, referring to my German descent, "you are an instance of the correctness of my theory." Bismarck, however, did not think that this blending of races was always an unmixed blessing. Thus he held that the English in associating with the French were apt to lose a deal of their veracity in exchange for the greater urbanity they acquired. I have heard him say: "Beware of the Englishman who speaks French too well."

We returned by a road which led through the village. This was the first time I had seen Friedrichsruh en fête. In accordance with a pretty 
German custom, the Schloss was decked inside and out with evergreens arranged in garlands and festoons spelling words of "welcome" and "good luck." Out of compliment to the nationality of the bride the Austria-Hungary flag was floating from the roof. Any number of photographers awaited the unwary at every turn of the country roads.

The Hamburg "Verein für Kunst und Wissenschaft," by Prince Bismarck's permission, was to hold a picnic in the afternoon in the Saxon Forest, and special trains had already brought several hundred people from Hamburg. The "Waldfest," as the Germans call such gatherings, is a peculiarly national kind of symposium, and, as such, of more than transitory interest to a stranger. Thus it was with great pleasure I learnt that the Prince and his family were going to take an active part in it.

Soon after lunch several brakes and carriages drove up, and we all got in pell-mell and drove out into the forest. Prince and Princess Bismarck, Count Herbert and his fanceee, Countess Rantzau, Countess George Hoyos, the mother of Count Herbert's bride, Count William and his wife, Baron and Baroness Merck and myself making up the party.

It was a pretty sight as the carriages drove through the beautiful forest of beeches and drew up in front of a crowd of hundreds of picnicing Hamburgers of both sexes. The ladies were dressed in bright summer colours, and stood at long tables, which had been set up under the trees. 
Before the Prince had time to step out of his carriage he was surrounded by ladies, who held up flowers to him. Several of them attempted to kiss his hand, a form of salutation on their part he was accustomed to return by a kiss on the cheek. He was at once escorted to a place of honour which had been reserved for him and his family at one of the tables.

As soon as the Prince and his guests had taken their seats, a spokesman of the Hamburg Society gave expression to the delight which they all felt in seeing the Prince and his family amongst them. When the cheers which greeted his words had died away a loving-cup was passed round at which Prince Bismarck took a hearty pull. The Prince in reply said that although he had lived twenty years in these woods, he had never yet seen them wear so bright an aspect as on the present occasion. Never before had it fallen to his lot to gaze upon such a bevy of beauty. Would that he could often be greeted in the forest by such bright faces, and that it always presented so rich and blossoming an appearance! He concluded: "To the health of the ladies."

The company joined in singing a German song.

One of the committee drew the Prince's attention to an archaic barrow in the immediate vicinity, the coping of which had up to that moment been hidden by shrubiery. A number of gnomes made their appearance, issuing from the bushes. They tore down the undergrowth and assiduously fell to 
digging. In a few minutes they had unearthed a colossal figure of Roland, which bore the features of Germany's great Chancellor. In a twinkling Roland was wreathed about with garlands, the dwarfs threw their spades aside, and with emblazoned shields in their hands, grouped themselves round the statue. While the Prince was scrutinising his own presentment in mediæval costume, somebody called out, "Let the ladies form groups round about 'Roland,' so that we may enjoy the pretty sight from where we are."

Amid much laughter and jesting, prompt and ample justice was done to the idea. A galaxy of young girls encircled the mound as with a manycoloured garland, while the gentlemen started singing the song, "Roland the Giant in the Rathhaus of Bremen," to the accompaniment of instrumental music. When the last strains of the song died away, the ladies waved their handkerchiefs and gave three cheers for Bismarck. For two hours the Prince and his family remained on the scene, conversing freely with those present. Dancing followed on a raised flooring specially erected in the open air for the occasion. Loud cheers greeted the party when the Prince left.

At dinner reference was made to the "Waldfest" and the ordeal the Prince had undergone, involving, inter alia, the partaking of the champagne loving-cup and joining in the meal of the holiday makers, although he had only just got up from lunch at home before starting. Bismarck said that 
he had never liked German champagne, and related the following incident in illustration :-

"On one occasion I was dining with $\mathrm{His}$ Gracious Majesty (the present Emperor). I had some champagne in my glass, the taste of which made me suspicious. When the butler again passed I tried to get a look at the label on the bottle, but this was impossible, for a napkin was wrapped round it. I turned to the Emperor to inquire the name of the particular brand, when His Majesty blurted out that it was indeed German champagne-Deutscher Schaumwein. 'Yes,' the Emperor said, 'I drink it from motives of economy, as I have a large family, and I have strongly recommended it to my officers for the same reason. Then, again, I also drink it from patriotic motives.' Thereupon I said to the Emperor, 'With me, Your Majesty, patriotism stops short at the region of my stomach."

Somebody reminded the Prince that one of his ancestors had distinguished himself by discovering a new dish. "Yes," he said, "a great personageI think it was a bishop-once came on a visit to one of our family, and my ancestor hit upon the idea of putting pigs' ears into pea soup. It called forth approval, and this was the origin of the well-known succulent pea soup with pigs' ears." Referring to the love of good cheer, which is a hereditary trait in his family, Bismarck said that his eyes often watered, and he believed it was the wine his ancestors had drunk to excess which thus came back 
to the surface from his eyes as a punishment to him for their sins.

Next morning Prince Bismarck came out of his apartments a little later than usual. It was whispered in his family that yesterday's "Waldfest" had been too much for him, and that he had slept badly. I met him at the front door towards midday, and he asked me to take a stroll with him before lunch. He did not seem in very bright spirits, and sat down on the first bench we came to. He said he did not feel very well. I replied that after he had gone to bed last night I had heard Princess Bismarck express her fear that he would pass a bad night owing to the festivity in the forest. She had said that he was perfectly "incorrigible" in his good nature towards strangers, which they abused.

"What am I to do?" he replied in an apologetic tone. "Surely I could not be rude to them!" (unhöflich).

Bismarck told me that a recent visitor to Friedrichsruh-I forget who it was-had spoken of a book in his possession which he said was full of the grossest libels on him (the Prince) and his family. He had not paid much attention to it, or even asked to look at it at the time. The thought, however, occurred to him afterwards that it was rather a strange proceeding to bring a book of such a description to the house, to talk about it, and then take it away again without showing it to him. Bismarck asked me whether I thought that 
from his description I should be able to procure him a copy. I replied that I would try, and wrote at once to a Berlin publisher. The next morning but one the book arrived. It was anonymous, and on glancing through the pages I found that it was, from beginning to end, a tissue of the foulest slander imaginable on Prince Bismarck and all his family, from the earliest historical data down to the present day. There was hardly a crime in the calendar that was not imputed to him or some member of his family, that of having Jewish blood in his veins being his most venial offence.

In England our newspapers are never tired of telling us of the cruel restrictions on the liberty of the subject on the Continent, of the suppression of public opinion, and the prosecution of its exponents. But no publisher in England would dare to put his name to anything approaching such a libel on an English public man and his family. $\mathrm{He}$ would in all probability be ruined by the damages which an English jury would award to the prosecutor. And yet in Germany there was apparently no legal let or hindrance to the sale and distribution of this most venomous of libels. No wonder Prince Bismarck was never tired of asserting that envy and Schadenfreude were the characteristic vices of his countrymen; that these vicious qualities were a legacy of their painful political past.

I gave the book to the Prince, and after he had perused it he told me that he thought it must be 
the production of a man named Gehlsen. He was connected with a paper called the Reichsglocke, to which the Empress Augusta had now and then subscribed. Bismarck did not appear to be annoyed by the contents of the book-they were obviously beneath his contempt. At the same time the emphasis of his reference to the Reichsglocke and the stern expression of his features gave me the impression that he still felt the sting which that disreputable sheet had inflicted in years gone by. He asked me to allow him to keep the book. The same evening, after dinner, he brought it out and read some passages to his visitors, who were highly amused. When he had finished he said: "Well, I have often been accused of prosecuting people for personal insults, whereas in reality I have never done so except in connection with my official position. But really I must think this matter over, whether it is not a case in which I ought to take action."

Next day we made up a party, walked over to Sachsenwaldau, and took tea with Baroness Merck. One of the company told the following story as typical of Prince Bismarck's delicacy of feeling. Among his friends in later life was a wealthy neighbour, who was a great judge of horseflesh. The Prince once asked him to be kind enough to choose a suitable saddle-horse for him, which, considering his great weight, was not an easy thing to find. His friend undertook the commission, and executed it to Bismarck's complete satisfaction. Bismarck asked the price of the 
horse. The other, who was very proud of the Prince's friendship, wished to be excused mentioning the price. He begged to be allowed to offer it to the Prince as a present. Bismarck did not reply either yes or no, but sent his friend in return a valuable silver tankard inlaid with rare coins, a present which must have cost as much, if not more, than the horse. To-day it is shown with pride as a present from the great statesman. Its connection, however, with a certain saddle-horse remains discreetly unmentioned.

One of the pleasantest reminiscences of this most sunny of all my visits to Friedrichsruh was my meeting with Professor Heinrich von Sybel, the eminent German historian. I had made his acquaintance some years before in Berlin, and he had given me an autograph copy of the first volume of his great work, Die Begriindung des Deutschen Reichs. On the present occasion I went to the railway station to meet him on his arrival. Herr von Sybel had been among Bismarck's political opponents in the old "Conflict" days, as I well knew, but he had long since found grace in the unstinted recognition of his great countryman's deserts, and nobody could have been a more devoted adherent of Bismarck's than Heinrich von Sybel in his latter days. Herr von Sybel was a man of singular charm. He possessed a quiet grace of manner, an amiability which carried with it an impression of sincerity-qualities not always to be met together. His reception at Friedrichsruh 
was most cordial on all sides. Prince Bismarck took him into his room after lunch, and remained long closeted with him in conversation-a very unusual distinction. He also drove out with Sybel later in the afternoon. It was a matter of common knowledge at the time that Sybel had been somewhat curtly treated by Count Caprivi, who had forbidden him further access to the Prussian historical archives, which, under Prince Bismarck, had been unreservedly at his disposal. He spoke of it without bitterness, but he told me that it had been such a blow to him that he had despaired of being able to keep his contract with his publishers and finish his work. They had, however, declined to release him from it, and agreed to his continuing the work without the assistance of official documents.

He told me that he was convinced that the reason of this unusual procedure on the part of the Government was that they were afraid he might turn too much light on events which would glorify Prince Bismarck. Sybel took it as a compliment that the Government appeared to believe him incapable of 'correcting' history-in the sense in which French card cheats-commonly called Grecs-are said to correct fortune ("corriger la Fortune")-in order to curry favour with the ruling powers.

Herr von Sybel stayed to dinner. It was a beautiful evening; Prince Bismarck's easy-chair was taken out on to the terrace and the visitors grouped round him as he sat smoking his after-dinner pipe. 
Herr von Sybel related some well-known facts connected with the wonders of the heavens. Where the naked eye can only discern a few thousand stars, the sensitive photographic plate shows the presence of millions; an endless series of solar systems each perhaps far mightier than our own. Further, that whereas the light of the sun only takes about eight minutes to reach the earth, there are planets the light of which takes thousands of years to perform the same journey. The contrast between eight minutes and thousands of years produced an impression upon the company. Bismarck, possibly moved by some thought connected with his sincere religious belief, observed, with an arch smile: "Are they really sure of it all?"

Next morning an Englishman accosted me at the gate of the Schloss and asked me when Prince Bismarck was likely to drive out. He said that he had come all the way from New Zealand, and that he would like to be able to say on his return that he had seen Prince Bismarck. As it happened the Prince did not drive through the front gate on that particular day, and thus, I fear, the New Zealander left without his wish being gratified. At dinner I related the incident to Prince Bismarck. To my surprise-for at times he was really persecuted by strangers - he replied that he was sorry to think that a man who had come from such a great distance should be disappointed when it was so easy to gratify his wish, and that he regretted that I had not come and told him in time. 
The forthcoming wedding and the projected journey of the Bismarck family to Vienna formed a staple subject of conversation among them; the dresses to be ordered, the presents to be bought, etc. There was, however, one feature connected with it all which struck me very forcibly at the time; for nothing before or since so thoroughly brought home to me the bitterness of feeling which the events of the last two years had caused the Prince and his family. It was their utter unconsciousness of the enthusiastic ovations which awaited Bismarck on his way to Vienna. So deep had been the sense of injury endured that he who had ever shown an almost unerring instinct in estimating the current of popular feeling - the trend of the Volksseele-the soul of a people-not only in Germany but also in foreign countries-in this instance was at fault in his estimate of his own countrymen. For whereas it was sufficient to have travelled cursorily through the country and mixed freely with different people as I had done to feel convinced that Bismarck's journey would prove a triumphant progress, he himself thought it would be fortunate if he and his family got to their destination without encountering actual demonstration of hostility. As is well known today, the different stations of his journey-Dresden, Vienna, Munich, Kissingen, Jena-were so many stages of a more than regal progress. 


\section{CHAPTER X}

VISIT TO PRINCE BISMARCK AT KISSINGEN

$$
\text { JULY, I } 892
$$

G ROM Friedrichsruh I went to Rudolsbad, a F pleasant little spot in Thuringia, where a wealthy manufacturer has built a luxurious hotel fitted up with every kind of thermal bath. Whilst there I read the accounts in the German papers of Prince Bismarck's triumphal progress through Germany to Vienna and of the bursting of the storm engendered by the treatment he had received from official circles in that city. To the general public these things already belong to the past; not so, however, to the student of Bismarck's life, or of the history of Germany, the sympathiser with her unhappy past, the well-wisher for her great future. To them the story of those days is still full of significance; it brings out the meaning of the words wrung from Herr von Treitschke, that the Unifier of Germany had experienced a fate as tragic as that of Themistocles. For:

"Fate is a sea without shore . . . .

And bitter as blood is the spray, and the crests are as fangs that devour." 
On the one side it called forth enthusiastic demonstrations of sympathy, whilst all the hatred and malice pent up in the national character broke forth and found expression in the extraordinary words of a well-known German parliamentarian, that "moral loathing" (sittlicher Ekel) was the only feeling Prince Bismarck's conduct inspired. I have still a few newspaper cuttings by me from those exciting days in which the Berlin correspondents of certain foreign newspapers unctuously assure their readers that "the opinion of the Unifier of Germany has ceased to excite much public interest-the Government does not consider his attacks worthy of a reply."

It was a source of bitter mortification to German patriots to note the mocking delight, the rancorous joy of the foreigner gloating over the Germans at their old game of mutual rending and recrimination. For the sum of it all was another manifestation of the national curse of discord, which the foreigner was always eager to profit by to the pain and sorrow of Germany.

During my stay at Rudolsbad I received a letter from a well-known publishing firm in Stuttgart, asking me to write an article for them dealing with Prince Bismarck's home life. It was intended to serve as a letter-press introduction to some drawings of the well-known illustrator, C. W. Allers. These the firm in question was about to publish in the form of an album, which afterwards became one of the most successful publications 
ever issued. More than six thousand copies, at fifty marks each, were disposed of within a few weeks, affording proof positive of the extraordinary interest in everything pertaining to Bismarck taken by his countrymen, even during that critical period.

The Stutgart firm, in their letter, made the acceptance of the article dependent upon my obtaining the assent of Prince Bismarck to the project, and suggested my going to Kissingen, where the Prince had just arrived to take the cure, expressly to ask him whether he was agreeable to my undertaking the task. It struck me as being somewhat unusual to ask a man's own consent in such a case, more particularly such a man as Prince Bismarck. However, for the moment, I was only too glad of an excuse to pay him a visit; so I accepted the terms of the Stuttgart publisher and wrote at once to Kissingen, asking permission to come and see the Prince. I received the following reply by telegram, dated Kissingen, July 2 nd :-

"Your visit is always welcome to the princely family.*

"(Signed) Chrysander."

I started the same evening for Kissingen. Somewhat early next morning we had to change carriages at a minor Bavarian station. It was a lovely summer morning - a Sunday. The church bells of the town were ringing, and crowds of peasants, smoking their pipes, flocked to the train. All was cleanly, bright, and serene, as it can only be where the iron

* Ihr Besuch fürstlichen Herrschaften stets angenehm. 
heel of industry has not yet obliterated nature's bright colours and stamped mankind a sooty black. And nowhere are such primitive conditions to be met with in more charming simplicity than in the south of Germany.

On a former visit to Kissingen I had already seen sundry birthmarks of German unity to be found there. Bullet-holes in the walls of houses recalled the Battle of Kissingen in 1866 , when the Great Surgeon performed the Cæsarian operation (den Kaiserschnitt) on half-distracted Germania. He had long since become a popular personage at Kissingen, as a great surgeon is indeed entitled to be among those he has benefited by his science.

On my arrival I started out on foot towards the so-called "Obere Saline," where the Bismarck family was staying. I had been walking some time, and could not have been far from my destination, when I saw a cloud of dust in the distance. It was a Bavarian Court carriage and pair driving rapidly past, containing Prince Bismarck and Professor Schweninger on their way to the Saline, where I knew the Prince took his bath every morning about eleven o'clock. I turned my steps back in the hope of meeting the Prince after his bath. A crowd of people, mostly summer visitors to Kissingen, was in front of the baths in expectation of his appearance.

I had waited about half an hour when, suddenly, the crowd rushed towards the entrance of the baths, and a chorus of "Hurrahs" and "Hochs" 
rent the air. Bismarck, wearing his broad, black felt hat, accompanied by Professor Schweninger, came out of the building walking erect with his typical military step. Many ladies pressed forward, some of them proffering flowers; others attempting to kiss his hands. Slowly the Prince worked his way through the crowd, assisted by Schweninger, who was soon encumbered with a load of flowers. They both gained the other side of the road, crossed a bridge which spanned the River Saale, and took a pathway towards a wood in the distance.

There was something very striking in the attitude of this crowd. With all their boisterous enthusiasm, their eagerness to see as much of Prince Bismarck as possible, one and all-men, women, and children-respected his privacy to such an extent that not a single person, except myself, followed him and Schweninger across the bridge. Motionless and silent for a long time, they stood as if rooted to the spot, lining the bank of the river, looking after the Prince's figure, sadly, I thought, as he slowly receded from the view in the distance. Never have I witnessed the instinct of veneration so simply or more beautifully illustrated. It was as though, in the pregnant words of Nietzsche-

"An involuntary silence-a drooping of the glance-a cessation of all gesture-which thus expresses that a soul feels the vicinity of that which is worthy of reverence!"

For the moment it all seemed a dream-one of those dreams in which in the space of a few 
THE ANNIVERSARY OF SADOWA 173 seconds we live through our life from the cradle to the grave. A thousand years of German history passed before my eyes. Such was the pathos of the scene. It was warm with the breath of German folk-lore. It recalled the nation's history in which the element of tragedy, long before the days of the Hohenstaufen Kaisern, is so often mingled with scenes of rural life. I thought of the fabled ratcatcher of Hamelin, leaving the ungrateful town with its children and suddenly disappearing from the gaze of the despairing townsfolk. And here, on the $3^{\text {rd }}$ of July, the anniversary of the victory of Sadowa, stood its real German hero, grown white in the service of his country, slandered and maligned, stung to the quick by the cruel pang of ingratitude of those whose position he had fashioned. $\mathrm{He}$ is an old man now, and he is slowly going out of sight, disappearing from the vision of townsfolk and children, leaving behind him a lingering picture of tragic greatness, unmingled with the memory of a wrong to any one soul in the hearts of the people, never, in all probability, to behold him again.

Bismarck only came to Kissingen once again in the following year, and was taken seriously ill during his stay.

Some little distance from the bridge I joined Prince Bismarck, and offered to carry some of the flowers with which Schweninger was laden. I told the Prince of the unusual suggestion of the Stuttgart publisher, and endeavoured to anticipate 
what I knew his answer would be by the tone in which I spoke.

"Yes, surely," he replied good-humouredly. "I cannot be called upon to give my consent to a project which is intended for my own glorification."

"No, certainly not," I rejoined. "But at least it has procured me the privilege of seeing Your Highness again, and on such an auspicious anniversary too as that of the Battle of Sadowa."

My reply seemed to satisfy him, for he asked me to accompany him and to come to lunch. I availed myself of his good humour to tell him of the troubles of one of his former colleagues, who was very unhappy over the thought that the Prince believed him to be ungrateful because he had remained on in office after Bismarck had retired. $\mathrm{He}$ had told me that he could not sleep at night, for it pained him so to have heard that the Prince had spoken disparagingly of him. Bismarck listened, smiling at my attempt to palliate the action of his subordinate, and with that merry twinkle of his eyes when about to utter something pointed, he said, quoting the excuse of the rogue in a German play, "I may be weak, but I am not a scoundrel."

As we walked on and entered the wood a dark figure startled us standing between the trees, waving a black velvet cap high above his head. With an expression of great excitement on his features he called out vociferously_ " Hoch Fürst Bismarck!"

The Prince stopped short and spoke kindly to 
the man, asking him where he came from and what might be his calling.

He said he was a Jewish rabbi; that he lived in Russia, was taking the waters at Kissingen, and that he had long wanted to see the Prince.

As we passed on Bismarck said, "Did you notice that man's head? There is something very peculiar about the Jews; the head is almost at right angles to the neck. A Jew could be guillotined standing."

In walking along the forest pathway the conversation turned upon the action of the Government towards Bismarck and the attitude of the official Press in connection with it. Whilst the European Press was excitedly discussing the situation, he treated it with the utmost sang-froid, not without a touch of grim humour. The Norddeutsche Allgemeine Zeitung had just made a vicious onslaught on him; Bismarck said in a tone of contempt-

"It was I who taught those dogs to bark, and they now think that I am to be frightened by their noise, but they are very much mistaken."

I told him I had seen a paper which took his part and advised the official Press not to go too far, as they would never be able to intimidate a Bismarck, whilst they might only succeed in making him more angry.

"Oh no," he said. "They need not be afraid, I shall not lose my temper."

In speaking of Count Caprivi the Prince said"I feel that after all my knowledge of character 
is very defective. I took Caprivi for a silent man because I always found him so-a sword-une fière lame-but now I see he is only a talker."

We had now been walking some time, and all three sat down on a bench under the trees, giving a beautiful view of the valley of the Saale and the woodclad hills rising in the distance. It was essentially one of those charming scenes such as inspired a German poet with the words "Der liebe Gott geht Durch den Wald." Yes, while God was present in the glade, the devil of slander-the old malleus maleficarum of past ages-was busy in the printing presses of the capital. Never before or since -not even when standing by his deathbed at Friedrichsruh-did I realise the tragedy of Bismarck's old age so keenly as in this lovely spot with its dark background of discord and malevolence.

On resuming our walk through the wood the pathway brought us back into the open valley. A restaurant lay to the left most picturesquely situated in a garden. A pretty waitress stood at the gate with some flowers, which she offered to the Prince. He took them from her, bent down, and gave her a kiss in return.

In the distance to the right, across some fields, we could discern the Obere Saline. A large quadranglar building, in one of the wings of which Bismarck was staying as the guest of the Regent of Bavaria. Thither we wended our way. On our arrival Princess Bismarck came in, and shortly afterwards luncheon was served. One or two other 
guests, besides Professor Schweninger and myself, were present, but I do not recall their names.

Princess Bismarck was in far better health and spirits than usual, and had evidently enjoyed her recent stay at Vienna on the occasion of her son Count Herbert's wedding, concerning which she had much to tell. He was now on his honeymoon, and a letter had just arrived from him-always a glad event in the family-describing his experiences, even to the details of the expenses of the hotel at which the happy pair were staying. But what had particularly delighted the Princess was her visit to Munich, where they had been the guests of Professor Lenbach. The ovation tendered to Prince Bismarck by the population, as well as the town authorities, of the Bavarian capital, in which he at one time had been looked upon as an archenemy, was of an unprecedented character.

The unpleasant incidents connected with Prince Bismarck's stay in Vienna must have still rankled in his mind, although he did not specially refer to them at table. That such was indeed the case was evident from the expression on his face when Princess Bismarck related the story of the conduct of Princess Reuss, the wife of the German Ambassador in Vienna. It was as follows :-

When the order was received from Berlin that the German Ambassador in Vienna and his staff were to take no official notice of Prince Bismarck or of any member of his family or to accept invitations to the family wedding, Prince Reuss 
was placed between the alternative of asking to leave Vienna on private business or of simulating illness. Not being in very good health at the time, he chose the latter.

But his consort refused to share his diplomatic retirement. She was "at home" when Prince Bismarck called, and welcomed him as an old friend. She even jeopardised her husband's diplomatic career by taking the man who was under imperial bann upstairs to her husband's bedroom. Princess Reuss subsequently returned Prince Bismarck's call in person, and had a long chat with Princess Bismarck, to whom she said-

"You know, my husband is, after all, only an ambassador, and must obey instructions as long as he is in charge here. But I am the daughter of a German Sovereign Prince (the Grand Duke of Weimar), and I will not take orders of this kind from Berlin. Moreover, it is a great pleasure for me to meet you and your husband, and I am delighted to see you."

The Prince told us that, during his stay in Vienna, Prince Ferdinand of Bulgaria wrote to him from Coburg, asking whether it would be convenient if he came to see him. Bismarck replied that he was on the point of leaving Vienna, but he would be staying a couple of days in Munich, where, if convenient to Prince Ferdinand, he would be glad to see him. Prince Ferdinand thereupon came to Munich, and asked Bismarck's advice as to what attitude he should adopt in his somewhat 
difficult position as ruler of Bulgaria. Bismarck advised him to do nothing which might give offence. "Be cautious, and in your policy avoid anything which might ignite the spark which leads to conflagration. Play the dead (faire mort), I told him," said Bismarck, with a peculiar inflexion of the voice and a half-mysterious, humorous expression, opening his large eyes to their fullest extent and raising his hand. "You have shown the world you can float; don't try to swim against the current. Let yourself be driven gently by the stream, and keep yourself, as hitherto, above water. Your greatest ally is time-force of habit. Avoid everything that might irritate your enemies. Unless you give them provocation, they cannot do you much harm, and, in course of time, the world will become accustomed to see you on the throne of Bulgaria."

Ferdinand listened attentively, and, as if to apologise to the Princess for taking up the time of Bismarck with his own affairs, he turned towards her, and said almost plaintively, "Durchlaucht, ich regiere so gerne" ("Princess, I am so fond of governing").

I learnt subsequently that Prince Ferdinand was delighted with his visit, and immediately it was over gave vent to his feelings of satisfaction by saying"Yes, I have had half an hour's conversation with that great man; and let me tell you that I have learnt more in that short space of time than in previous years of communion with everyday 
folk. Yes, I went to him, and sat at his feet, notwithstanding the fact that in days gone by he sometimes treated me disgracefully-yes, disgracefully" (schändlich). "But I am not like other people who allow such things to influence their course of action. They do not influence mine, as I have shown in this instance. To be sure, there are no real monarchs left nowadays. Such as they are, they are men without initiative, resource, or backbone. I am one of the few left of the true type of a ruler, for I am indeed a born actor." *

During lunch the post arrived, bringing a number of letters from different parts of Germany, some of them from corporations, expressing a hope that Prince Bismarck might either visit their town after his cure at $\mathrm{K}$ issingen or receive a deputation during his stay there.

One letter announced that Hans von Bülow, the eminent musician, was about to give a concert in Kissingen, and it was hoped that Prince Bismarck would honour the occasion with his presence. Hans von Bülow had quite recently created a sensation in Berlin, which had been widely discussed by the German Press. In the course of one of his concerts he had called upon the audience to rise and give a cheer for Prince Bismarck, a suggestion which had been resented by those present. Whereupon Bülow, in obvious allusion to a recent public ex-

* It is currently told of this up-to-date ruler of Bulgaria that when he has granted an audience to somebody, and the visitor has passed out, Ferdinand usually gives vent to his sense of gratification in the following words :- "Encore un que j'ai roule." 
pression of a high personage, that "whoever did not feel happy in Germany had only to wipe the dust of the country off his feet," took out his pocket-handkerchief and ostentatiously wiped his boots. Bismarck appreciated this as an instance of what he used to call "backbone," though he was not anxious to be made the subject of another sympathetic demonstration, with its sensational developments, for he said-

"I hope they will not bring that excitable little fellow after me here."

Professor Schweninger drove me to the railway station. He told me what a privilege it was to be able to devote himself to preserving Bismarck's life, and that he thought the Prince had a fair chance of attaining the age of the old Emperor William. 


\title{
CHAPTER XI
}

\section{BISMARCK'S BIRTHDAY}

\author{
APRIL IST, I 893
}

T ARRIVED at Friedrichsruh on the 3 1st March, 1 and found the Prince in the park, where we were shortly joined by Herr von Lenbach. $\mathrm{He}$ embraced Bismarck, who kissed him in return. We walked back together through the village, which was already in festive array. Flags and garlands of fir decked the houses. The quaint little post office was all life and bustle. An extra staff of four telegraph clerks and two carriers had arrived from headquarters, for telegrams had already begun to pour in, hundreds of them from early dawn. Each postal train had brought cargoes of presents of every imaginable variety from all points of the compass. Liqueurs came from Russia, sausages from Bologna, beer from Munich, wines from the Rhine, the Maine, and the Moselle, pâtés de foie gras from Strassburg, plovers' eggs from Jever, books in gorgeous bindings from authors, statuettes from sculptors, besides waggon-loads of flowers, wreaths, and plants from everywhere. 
The front of the Schloss has gradually assumed the aspect of a quay where goods are unloaded, and a staff of servants is busy all day long unpacking the boxes and stowing their contents in a suite of rooms set apart for the purpose. Every room is occupied by visitors, and not all have been accommodated who had direct claim of relationship. It was a difficult matter where to draw the line, and it was suggested that Herr X. might, at least for this occasion, stay at the inn, which he would willingly have done. But Princess Bismarck will not give up those she likes to see under her roof to please anybody. Her inexorable decision is : "Macht was Ihr wollt, aber Der geht mir nicht aus dem Haus" ("Do what you like, but he shall not leave the house").

All the family and several of the nearest friends have arrived by the evening to celebrate the morrow and toast the birthday "child," as the Germans quaintly call the recipient of birthday honours, whatever be his age. Count Herbert Bismarck is there radiant by the side of his young wife; Bismarck's daughter, with her husband. Bismarck's sister, Frau Arnim, is hourly expected. Franz von Lenbach has brought his beautiful wife with him from Munich. He is busy in the drawingroom making a sketch in pastel of Countess Herbert Bismarck. Professor Schweninger, the everfaithful, just arrived, is also present. For although only recently recovered from a serious illness, he knows that his authority will be required to-morrow 
to see that Prince Bismarck's good nature is not trespassed upon to the detriment of his health by over-enthusiastic visitors. So he has come expressly all the way at one stretch from the sunny South to take his privileged part of authoritative guardian.

The Ist of April is ushered in by lovely spring weather. Everybody is stirring about earlier than usual in view of the holiday character of the day. The hum of the crowd is audible from the inn, as also from the road and the railway station, for the early trains from Hamburg and the neighbourhood have already brought a large number of people together, who are awaiting developments, sitting in the open air over a glass of beer or a cup of coffee.

Professor Schweninger is the first to knock at Bismarck's bedroom door with a bouquet of flowers and good wishes for his "prize patient." The Prince's dependents-foresters, gamekeepers-the village doctor, the schoolmaster, have donned their best clothes. Numbers of deputations are arriving from different parts to present congratulatory addresses in person.

Bismarck is still in his private apartments, invisible to his visitors, receiving the morning reports from his secretary, or engaged in conversation with Princess Bismarck. When he comes forth it is in the undress uniform of the Cuirassier Regiment, of which he is the honorary chief. It is only on rare occasions such as this that he varies his attire from the usual black redingote. The 
birthday presents have been arranged in one of the rooms on the ground floor. It is only possible to find room for the floral tributes by distributing them through the different apartments. Bismarck takes a glance round, and is especially pleased with the mány beautiful devices of flowers from all parts of Germany, notably from large towns, such as Munich, Hamburg, Frankfort. The Oberbürgermeister of Cologne-Herr Becker-the once notorious red Republican, has sent a most elaborate floral design and an official letter of invitation to the Prince to visit the far-famed cathedral city.

The Prince has an arduous day before him, and it is doubtless by Schweninger's advice that, before seeing any visitors, he takes a short solitary walk in the grounds of the Schloss. As the stalwart figure passes among the trees, visitors instinctively remain behind, and only hear from afar the burst of cheers which greets him every time he comes in sight of the eager crowds that line the skirts of the park. It is not a favourable time to come to Friedrichsruh, if you hope to enjoy a little of the Prince's company yourself. You must be content with looking at him. Already drums are beating, the "Veterans' Union" is coming through the village in full marching order, and the various civilian deputations, in dress coats, black top hats, and white kid gloves are waiting to present their good wishes in person.

The University of Bonn, or rather, the students of that University have sent a deputation in full 
academical dress-jack-boots, special ribbons, and bandoliers - to congratulate the Prince and present him with an illuminated address. He received them in the drawing-room just before lunch. This visit of the Bonn students had a somewhat peculiar history. On the occasion of the previous birthday of the German Emperor, the Bonn students had been prevented by official pressure from including a toast to the health of Bismarck in the programme, as they had wished to do. This had been a grievance ever since the month of January, and was now disposed of by this visit of the deputation. After listening to their address and making a suitable reply, Bismarck handed a rose from a bouquet he held in his hand to each of the students, and it being lunch-time, he invited them, as well as the spokesmen of several other congratulatory deputations, to be his guests. One of these representative bodies hailed from some little town in Saxony. This fact is fixed in my memory owing to an unfortunate allusion I happened to make in the course of the lunch concerning the poor quality of the detestable compound served at some Saxon railway stations known under the name of "Bliemchenkaffee." My remark was an unlucky instance of innocent trespassing on patriotic sensibilities. It took me some little time before I could smooth down those ruffled Saxon feathers.

This lunch turned out to be a Gargantuan Feast. It lasted, with interruptions, about three hours, during which time a never-ending stream of visitors 
came and took their places as soon as room could be found. Some of the birthday offerings of an edible nature are brought in and are greeted with acclamations of approval.

"Let us tackle the solids," says Bismarck goodhumouredly, taking stock of an enormous Bologna sausage, "the liquids will keep."

The students are the centre of attention for the moment, and Bismarck enters into conversation with them. Among other things, he referred to his son Herbert's duel as a Bonn student and how, through the negligent treatment by the surgeons of a swordcut, he had nearly caught blood-poisoning. His father came expressly to Bonn at the time and fetched him home.

We had been at table about an hour or so, when the sound of a well-known patriotic song-the burden of which consists of the sorrows of "Seagirt Schleswig-Holstein" - came through the windows of the dining-room, which gave out on to the park. We had all been so absorbed in the conversation at table that nobody seemed to have looked towards the windows, where an extraordinary sight met the eye: a crowd of middle-aged men, dressed in black frock-coats and wearing black silk hats. These head-gears gave the assembly a sombre appearance, for they were of every imaginable shape and presumably of every period-some of them such as are worn by sextons at funerals in certain parts of Germany. Many of those present were veterans of Germany's wars, for they 
wore medals and ribbons. They came along in military fashion till about fifteen hundred of them formed one compact mass in front of the terrace. A rousing cheer thrilled the air and stopped all conversation. Prince Bismarck rose from the table and with Dr. Schweninger by his side passed out to greet his visitors. They all simultaneously uncovered as Bismarck stepped on to the terrace, whither we followed. A Dr. Wallichs, a former member of the Reichstag, delivered a stirring address from among the crowd in which he eulogised the services of Prince Bismarck in connection with the union of Schleswig-Holstein with Prussia. Thunders of applause, of "Hochs" and "Hurrahs" followed his words.

Prince Bismarck, in reply, referred to the difficulties he had encountered in days gone by in his endeavours to bring about a settlement of the Schleswig-Holstein question. Whilst he was still in Frankfort he had come to the conclusion that the question itself was like a "worm that could neither live nor die"; how he gradually became convinced that a settlement could only be brought about by means which he indicated in the Holstein dialect, "Dat walt Gott un kold Isen" ("This must be decided by God and cold steel ").

The Prince's address had an electrical effect on his audience. Many of those present were moved to tears whilst listening to the old campaigner's reference to what was really the first act in the great drama of German unity, the forcible settle- 
ment of the Schleswig-Holstein question by blood and iron.

The Prince begged his audience to put on their hats to protect themselves from the sun. It was a peculiar sight to see the fifteen hundred old "tiles," as by word of command, resume their places on fifteen hundred heads! It gave a sad, an almost uncanny look to the crowd, as if they had risen from the dead. For in fact nearly every one of the princes and statesmen and soldiers who had played leading parts in the Holstein question had already gone home, nearly all but "Die eine hohe Säule," the one rugged pillar which stood erect before them, whilst enthusiastic cheers broke forth-a surging sea round a grey granite rock. There was a touch of majesty, of pathetic majesty in it, not easily to be forgotten.

Bismarck insisted on descending the flight of steps which led from the top of the terrace among the crowd. Hej seemed to want to warm his heart by contact with those whose narrower nationality and whose share in past struggles recalled his own first great political triumph, the heyday of his militant prowess-

"This were to be new made when thou art old, And see thy blood warm when thou feel'st it cold."

It was obviously impossible to ask fifteen hundred people to come up into the Schloss; but the Prince invited the leading members of the deputation to partake of his hospitality. 
The dining-room was again crowded with visitors, who kept coming and going far into the afternoon. It was a real “Tischlein, Deck' Dich" of German nursery lore; for the supply of eatables and Munich beer seemed practically inexhaustible. Prince Bismarck, however, did not stay very long. Dr. Schweninger persuaded him to retire for a short rest; there was still the evening to look forward to.

Bismarck's birthday was the only day of the year on which visitors were supposed to don a dress-coat for dinner, and wear such decorations as they might possess. Whilst some blazed forth in stars and crosses, Count Herbert Bismarck never wore anything but the Iron Cross of the second class which he won on the battlefield. Only one toast was proposed - that of Prince Bismarck's health by Professor Lenbach in stirring words. Little conversation of an interesting character took place, as the attention of the company was continually taken up by innumerable telegrams which were brought in at short intervals all through the evening. Some of them were read out aloud, and some, those from royal personages, had by etiquette to be replied to at once. One was from the Empress Frederick. A message came from some school children in England-from Sherborne, in Dorsetshire, where Countess Herbert Bismarck had lived as a girl. It was characteristic of him that the Prince insisted that this particular telegram should receive an immediate reply. Also "eighty grey- 
grown warriors" (ergraute Krieger) received an answer to their good wishes. All this necessitated a deal of writing, and pencils were in sudden request. Usually a large number of the wellknown Bismarck pencils of large dimensions, at least fourteen inches long, were lying about. On this occasion, however, not a single one was to be found. They had all been carried off as mementoes by the birthday visitors.

Prince Bismarck smoked a cigar in the course of the evening; the first and only one, he told me, for many years. His doctor had forbidden him tobacco with the exception of his long pipe.

Next morning (April 2nd), after breakfast, I went out with Lenbach for a stroll in the village and beyond into the woods. In the course of conversation he referred to the absurd reports which had from time to time appeared in the German and foreign Press about Prince Bismarck's great wealth and his supposed niggardliness in money matters. As a matter of fact, Lenbach said, "Bismarck is careful in money matters, as he has always been, by virtue of a habit which becomes second nature. His circumstances have ever been of a kind which required care. Even since he received a grant from his country, and the estate of Friedrichsruh from the Emperor William the First, Bismarck is far from being a wealthy man, as his position at all times has made great calls upon him."

We both had had ample opportunities of estimating the Prince's hospitality, which was on an exten- 
sive scale; besides, many things which made a great show in the papers as instances of homage paid him were in reality sources of expense to him. Thus, for instance, telegrams all the year round, particularly those he was by etiquette obliged to reply to, to royal personages on his birthdays cost a great deal. I remember one from the Sultan of Zanzibar and another from the Khedive of Egypt. Then again there were the allowances to each of his children. They might easily have made a wealthy marriage, but each married solely from inclination. Lenbach added that Bismarck's income was by no means so ample as to make these calls upon his purse a light matter. His estates brought comparatively little; Schoenhausen, for instance, next to nothing. The stories that Bismarck had shown the same ability in administering his private property as in the affairs of the German Empire were pure fables. As a matter of fact, he was very much under the influence of sentiment in dealing with his own landed property. He might have made far more money out of his forests, but could not bring himself to cut down his trees. And he often paid fancy prices when buying out peasants' pieces of land to round off his property. If anything, he was rather an unpractical landlord and often got the worst of a bargain.* Lenbach said that people were far too prone to give Bismarck's intellect and energy exclusive credit for

* Since Prince Bismarck's death the truth of all this has been amply demonstrated. 
everything he had achieved. "As a matter of fact, it is his heart which invariably seizes the essence of a problem at least as soon as his head. He does not care for art-at least not for painting-and yet in his way he is among the greatest of artists. For politics is one of the most difficult of arts, and like a true artist, his whole heart was always in his work. Bismarck reminds me very much," proceeded this great student of character, "of a steamship in which the boilers are too big for the shell of the vessel and threaten to rend its ribs. I have often been struck by his infinite kindness of heart (Milde). He has, if anything, too much heartfar more than anybody about him. He transcends his surroundings in this as in everything else. Few indeed are aware of the depths of Bismarck's feelings-for his is a most deeply sensitive and proud nature."

Lenbach dwelt on Bismarck's exquisite delicacy of feeling, his refinement. He said that even those harmless forms of lubricity, such as are current more or less in every society in after-dinner anecdotes, were entirely foreign to his nature. Bismarck was always a perfect stranger to such things. Lenbach told me that during all the years he had known the Prince, more than twenty years, he only remembered one solitary occasion on which he had ever heard him speak sharply, let alone say an unkind word to anyone. A manservant in leaving the room had carelessly slammed the door. This evidently had jarred on Bismarck's nerves, for he 
rang the bell, and when the man appeared told him in a curt tone that he was to leave at the end of the month. About a quarter of an hour afterwards he rang the bell again, and said in a mollified voice, "You may stay." That was all.

"And yet with all his kindness," Lenbach continued, "there is an atmosphere of loneliness, of solitude, of aloofness around him which has a depressing effect. When you first come from the outer world, particularly if you are versed in politics, you may inspire him with a languid interest for a time. But the effect is transitory, and his intimacy never gets beyond that. He has no friends left. It is a rare privilege to be allowed to meet such an extraordinary man; you look forward to see him, and you are delighted when you do see him, but with all his amiability, such is the oppressive weight of his personality that it is almost with a feeling of relief that you say good-bye to him."

We had now returned to the house, and it was lunch-time. With the exception of a touch of his chronic face-ache, Prince Bismarck appeared to be in good health as he came to lunch on this morning after his birthday. This was an important matter for those present. For if he happened not to be well, he was very chary of words, and the spirits of the company sank in proportion.

Now and then a point was made at table among those present to start some topic which might lead Prince Bismarck to take a part in the conversation 
without his being directly addressed and obliged to reply out of mere politeness, whether he felt inclined to do so or not. Thus on this occasion I began to relate that among my friends in London was an old Count X., a well-known revolutionary democrat of other days, who in 1848 had been a member of the Frankfort Parliament, and had since passed his life as a refugee in America, and subsequently in London. Count $\mathrm{X}$. was a slightly self-opinionated, but highly cultivated man. One of his fixed ideas-and he had a number of them-was that if Bismarck had only accepted the advice he-the Count-had tendered him by letter, I believe in the year I 866, German Unity might have been easily brought about without the shedding of a drop of blood. This was a subject on which the old Count loved to dilate. Thus whenever we met and he heard that I had been staying with Prince Bismarck, his first question invariably was, "Did you speak to him of me? Did you tell him that you knew me?" This question had already put me in a fix on several occasions, for in truth I had hitherto not mentioned his name to Prince Bismarck. I was loth to wound his feelings by allowing him to suppose that his importance did not warrant my bringing up his name. And yet I was naturally disinclined to tell a direct untruth, even though of so conventional a nature. So on each occasion I shuffled out of the difficulty as best I could, and at last mumbled something about Prince Bismarck's memory not recalling 
exactly, etc., etc. To this the Count immediately replied somewhat testily, "No, no, don't you believe it ; he remembers me very well indeed."

Just as I had got thus far in my narrative Prince Bismarck broke in-

"Tell him with my compliments that if he had fallen into my hands at the time and I had possessed the power, I would have had him hanged."

This unexpected sally provoked great hilarity, not, of course, the severity of the remark, for Bismarck was evidently half in fun, but the idea of the Count's surprise at the nature of the message he would receive-this tickled the fancy of those present.

The connection between revolutionists of other days and the most recent revolutionary methods of the present day was close at hand-for instance, the introduction of the so-called Middle-European time-table and the observance of Sunday after the English pattern. Both of these measures came in for Bismarck's strong animadversion. With regard to the so-called Middle-European table he said-

"I have been familiar with that project for years. It was a favourite whim of Moltke's; but as long as I was in office I would not listen to it. But now, of course, this is all changed. The new timetable may well possess certain advantages in connection with military affairs, such as facilitating the working out of the mobilisation of the army; but is this sufficient to warrant the introduction of so arbitrary a systematisation of time-rule into every 
walk of life? Just think of the ridiculous effect of the arrangement on our western frontier! At Aachen it is twelve o'clock, and at half an hour's distance by rail it is a full hour earlier. Here I am, for instance, under this blessed arrangement getting up half an hour too early and going to bed half an hour too soon!"

If this new fad excited Bismarck's raillery, the recently passed Sunday-closing law earned his hearty denunciation. He felt a contempt for it, not merely because it was copied from a neighbouring nationalthough he was justly suspicious of the imitative tendencies of his countrymen-but because in his opinion it was a foreign institution, neither called for by the needs of Germany nor suited to the character of the people-a piece of dilettante legislation.

"It is an indirect proof that this new-fangled Sunday legislation," he said, "is not a natural outcome of our. requirements that we do not feel sympathetically inclined towards it. Thus, if I were to meet a man working in the forest on a Sunday-which has now become a penal offenceit would never enter my head to denounce him. I should look upon it as an unwarrantable interference with the liberty of the subject."

The general opinion of those present was also strongly averse to this new-fangled legislative departure, and in full agreement with the Prince's strictures. Someone remarked that the social condition of the masses of the English people does not bear very eloquent testimony to the efficacy 
of English Sunday legislation nor seem to warrant its imitation. Another guest told a story of a lady in Berlin unexpectedly receiving the visit of some friends on a Sunday morning from the country. She was unable to ask them to stay to dinner because, since the introduction of the Sunday closure law, it had become an absolute impossibility to procure any provisions whatever from one end of Berlin to the other on that day.

The conversation drifted back from paternal legislation to the strong man of other days. Frederick the Great and his times were an inexhaustible source of anecdote to Bismarck; he told the following in his own inimitable manner:-

"When the great King returned to Berlin from the Seven Years' War, in the course of which the capital had suffered dreadfully, he rode through the Brandenburg Gate. He espied an apple-woman sitting there in the same place in which he remembered to have seen her at the outbreak of the war.

“"Well, my good woman,' he said to her, 'are you not glad to see us back again and to know there will be permanent peace now ?'

"' How am I to know that?' she replied.

“ ' Pack schlägt sich

Pack verträgt sich.' "*

"An officer endeavoured to get a comrade into bad odour with the King by telling His Majesty that

* "Ragamuffins fight to-day,

And are friends again to-morrow:" 
he was a drunkard. In a subsequent battle the latter's fitness was conspicuous, whereas his slanderer played a very poor part. When afterwards he defiled past the King at the head of his regiment, His Majesty called out to him in a voice of thunder, 'The sooner you take to drink the better' ('Sauf er Auch ')."

Bismarck told us that beneath old Frederick's roughness there was a fund of deep feeling, and he related the following as an instance of the King's endeavour to put right the results of his own violent temper. In the course of some military evolution the King, irritated by some mistake of a captain, ran after him with his stick in order to strike him. The captain ran away. The next morning the commanding officer reported to the King that the officer in question, one of the most efficient in the regiment, had sent in his papers.

"Tell him to come to me," said the King. The officer, in great perturbation, came.

"Good morning, major," he apostrophised the officer, who was speechless with surprise. "I wanted to tell you of your promotion, but you ran so fast I could not catch you up. Good morning."

Referring to his own memories of Berlin, Bismarck said a curious incident enabled him to be sure that his recollections of Berlin did indeed go back to the year 1818, when he was three years old. In that particular year his parents lived opposite the theatre, and a large fire broke out either in the theatre or some adjoining building. But what 
gave his memory the hall-mark of infallibility was that he distinctly remembered burning his fingers on the window-glass, which was heated by the fire.

Bismarck further remarked that he had a keen recollection of the Friedrichstrasse about that time, and particularly two shops had remained in his memory. One was a butcher's, and the other an English print shop.

In the year $184 \mathrm{I}$ his father treated him to a journey to England and France. He arrived in England at Hull. It was a Sunday, and the grimy place made such a depressing impression on him, who had only dreamt of beautiful agricultural England, that he lit a cigar as he walked along and started singing to himself in the street in order to get up his spirits. Somebody told him this was not allowed on a Sunday. So in disgust he set off for Edinburgh. It was on this journey he related that he was taken for an Englishman in France. The English were very unpopular in France at that particular time. Young Bismarck took his seat beside the driver of a post cabriolet bound from Paris for the northern road. After a long spell of silence the coachman turned to him and said, "Il y a diablement de vos compatriotes en France à present?"

"Comment donc mes compatriotes?" answered Bismarck.

"Eh bien, vous êtes donc Anglais?" the driver replied.

Somebody here made a remark about the great 
changes which France had seen since the days of Louis Philippe and M. Adolphe Thiers. Gambetta's name was mentioned, and Bismarck said that the story which had got into the papers at the time that the French statesman intended to pay him a visit was really true. Gambetta had travelled as far as Schlawe (if I remember rightly) on the road to Varzin, but he (Bismarck) had felt compelled to decline his intended visit on political grounds. This he regretted, as he would have been interested to make Gambetta's acquaintance. Somebody present who had met Gambetta en petit comite in Paris a short time before his death made a remark apropos of the low estimate in which the popular tribune in his heart of hearts held the French populace, and even their average parliamentary representatives. In speaking of the ruck of the Republican deputies, Gambetta had said, "On leur fait encore trop d'honneur en les qualifiant de sous vétérinaires de deuxième classe."*

It may be recorded as a curious verification of Gambetta's estimate of the status of his parliamentary colleagues that some time after his death an Alsatian deputy named Antoine, who indeed was a veterinary surgeon by profession, obtained some notoriety by his noisy championship of the French sympathisers in the lost provinces.

Among those who were present at Friedrichsruh on this occasion was Hermann Levi, the renowned

* "It is doing them too much honour to describe them as secondclass assistant veterinary surgeons." 
Wagnerian Kappellmeister, alas! since dead. Levi was a great friend of Lenbach, and was invited at his suggestion. He proved to be a very welcome guest at Friedrichsruh, both on account of his genial manners and his great musical talents, and was in consequence soon persona gratissima both with Princess Bismarck and her daughter. When he left in the evening I saw Countess Rantzau furtively hand him something dark-dark and underhanded was the manner in which he took and hid it under his great-coat. On the way to the station the secret leaked out. It was an old soft felt hat of Bismarck's. Levi went back to Munich a happy man.

Before retiring to rest I passed Dr. Chrysander's (the Prince's secretary) study and tapped at the door, feeling sure to find him still at work. There was hardly a square inch of flooring left where you could have dropped a pin; post-parcels and letters littered the floor. I was particularly struck by a number of letters, with printed envelopes, addressed to the Prince from all parts of the Austrian-Hungarian monarchy. There must have been thousands of them. Most of them were from individuals, but a great number came from societies and corporations. One was a tribute from a small town in Bohemia, which I append hereto. The terms in which it was written give it, I think, a lasting interest. It shows the veneration Bismarck was held in among men of the German race outside the confines of the Fatherland at a time when he encountered bitter 
enmity in the capital of the German Empire. I have a copy of the Berlin Freisinnige Zeitung of that date in my possession, in which it is given as an editorial opinion that the demonstrations on Bismarck's birthday would fall off considerably!

The Bohemian birthday congratulation was as follows :-

"Your Highness,-Millions of Germans who, in these days of ingratitude, have not forgotten that you are the national champion who created a great and mighty Fatherland for the German people, celebrate to-day in joyous spirits Your Highness's 78 th birthday.

"We Germans of the eastern zone have always looked up to Your Highness in love, gratitude, and veneration as the creator of Germany's greatness.

"Again on this day our good wishes go forth to you from beyond the mountains which separate us-our hearts joyously give vent to the wish :

"May God preside over Germany's destinies, and preserve Your Highness for many years yet to your people.

"(Signed)" [By the Town Clerk.]

One letter bore the curious address-

"Sr. Herzoglichen Hoheit, dem Herzog zu Lauenburg,

Bismarck,

Friedrichsruh."

"And every one of these," said Dr. Chrysander, "must be acknowledged; it will take me till well into the month of July to finish them," he added, smiling. It looked indeed a task sufficient to appal the heart of a less devoted worker, 
"But you appear to take it very kindly, Herr doctor," I said ; " it seems almost to agree with you, to judge by appearances."

"How could one help being happy near him?" was his ready reply. "He is so full of delicate consideration for everybody. Did you not notice the simple charm of his conversation to-day at dinner? Ah! it makes me very sad to think that it must all some day come to an end." 


\section{CHAPTER XII}

\section{PRINCESS BISMARCK}

\section{VISIT TO FRIEDRICHSRUH}

(CONTINUED)

APRIL, I 893

I $\mathrm{N}$ bidding good-bye to Friedrichsruh I little I thought that I should never see Princess Bismarck again. She died at Varzin in November of the following year, and I only returned to Friedrichsruh after the lapse of two years, in April, I 895. A noble monument has been set up to her memory by the publication of Prince Bismarck's Love Letters, and more recently still by Herr von Keudell, in his Erinnerungen an Fürst und Fürstin Bismarck.* Therein Prince Bismarck's consort is not merely portrayed as a devoted wife and mother, she is revealed to us as a lady of broad sympathies and deep soul-life (Seelenleben). This stamps her as a cultivated, high-minded woman - a pattern for those who care to look beyond their own immediate surroundings for noble types of womanhood.

My acquaintance with Princess Bismarck was

* Berlin und Stuttgart. W. Spemann. 
limited to my few short visits to her family, yet from the first I felt strongly attracted towards her. I was anxious to understand-to appreciate her individuality.

If, now that she is gone, I attempt to recall my impressions of a lofty nature, it is because I would lay them as tender flowers on the cold marble of her tomb.

It is a congenial task to linger in remembrance of one who has left deep traces of gratitude in our heart; but in reverencing the dead we do not court the applause of the living. There is at times a proud satisfaction in standing alone-apart-in the solitude of the night, and placing a few stones on the pyramid of a memory. A voice tells us that when the day breaks the true inwardness of our tribute shall be evident, and coming from the heart, it will live in the hearts of others.

Man may mark his personality on the map of the world, but it is meet that woman should rule within the four walls of a home. And domesticity played so large a part in the life of Germany's great Chancellor that one who during nearly half a century was its focus could hardly help being an object of great interest to the student of his life, even down to her most minute characteristics. Simplicity and sincerity-to which the very walls bore witness-were indeed so many marks of her hand. The whole style of the house was hers. It was her husband's as well; but had it not been hers too it could never have been manifested to 
"HER PRICE IS FAR ABOVE RUBIES" 207

the observer intent on taking even inanimate things as indications of living sentiments. To know Princess Bismarck was to realise what an amount of character can reveal itself in the ordering of a household-yes, even in the trifling task of compiling the menu for a meal. Everything was plain, and yet supremely excellent.

Princess Bismarck was singularly free from egotism. I do not mean that she was insusceptible to an effort to please her, for she was a woman, and welcomed the warmth of a sunny ray of sympathy. But she had no room in her heart for vanity, or for any other egotistical idiosyncrasy. Devotion to her husband and children monopolised her life. She possessed a gift not common even among kind-hearted women-that of making her home attractive to her grown-up children-even after they had married. When they were away she corresponded with them almost daily.

Unlike many gifted women, Princess Bismarck did not aspire to live a life apart, or, as the wife of a great statesman, to obtrude into politics and endeavour to influence her husband. What he did was at all times well done. She was content to live entirely for and through those who appealed to her affections and her sense of duty-conceptions which with her were almost dependent upon each other. Not that nature had set a narrow limit to her resources ; on the contrary, few women could possess a wider range of mental interests than Princess Bismarck. Her musical tastes are familiar 
to us through Herr von Keudell's pages. She was also an omnivorous reader, and in what she read it was essentially the human side of thingsdas Menschliche - the humorous, the pathetic in every walk of life-I might almost add, in every clime-which absorbed her. A letter, dated 27 th July, I889, from Varzin, in her own handwriting, lies before me. It is addressed to a Berlin library, from which she was in the habit of receiving books. There are seven books she returns as read, five she enumerates as being still in her possession unread, and a further list of seven new ones, which she asks to be sent on to her. Among the authors cited in these lists are Niemann, Waldzedlitz, Maurus Jokă̆, Junker, Voss, Wichert, Westkirch, Mollhausen, Bret Harte, Hans Hopfen, Julius Wolff, Stinde, E. Werner Conrad, Paul Lindau, Breidenbach, Braddon, Lewald, M. von Reichenbach, Marlitt, and Carlweiss. A respectable array of reading for one whose dominant thoughts and cares were centred in her home. There she ruled supreme. There she found no room for the great of the earth - kings or emperors, queens or empresses though they be. They were not near enough to her sympathies. She would not have their portraits in the house, although they were presents to her husband. They had to find their way to the bare walls of the museum of Schoenhausen, where I have seen them looking quite forlorn, Her Most Gracious Majesty Queen Victoria among them. Of crowned heads 
RELATIONS WITH ROYAL PERSONS 209

there was but one portrait at Friedrichsruh: a present from Lenbach-the old Emperor William, who had been kind and grateful to her "Otto."

Princess Bismarck's lack of veneration for rank even of a royal degree struck me as being all the more remarkable since the Prince, than whom no man was freer from the trammels of conventionality, down to the very last had a keen sense of what was due to those of royal blood. If irritated, he could tell an emperor that he would not allow him to trespass into his wife's drawing-room; under the influence of the amenities of everyday intercourse it was far different. He never made the slightest distinction between people of different stationmore particularly if they met under his roof-but for all that a reigning grand duke or princelet was something decidedly "extra" in his eyes-une autre pâte - and was treated as such. This was beyond his own volition, the natural result of inherited strong monarchical feeling.

No so with the Princess. She might have been a Republican, though I do not mean one of AngloSaxon race, rather the wife of a blunt Swiss burgher. She was free from that vanity which suns itself in the warmth of a regal smile. During many long years she had fulfilled the duties of representations in Berlin and carried them out with the quiet dignity and assurance of one born to a position in good society. Yet we know that her heart was never in the task. Not even the knowledge that her husband was the centre of all this glitter could 
obliterate the feeling in her that this was after all a fictitious world, one in which the genuine had scarcely any foothold. Not once did I ever hear her refer to a period which with others would have constituted past glories to dwell upon in fond memory as the only solace left for present neglect. Yet her thoughts would readily go back to much earlier times. On several occasions I listened to her reminiscences of her wedding-tour over the Alps. How "Otto," reckless as usual, did not possess a proper overcoat and caught a bad cold. At Venice they found the King of Prussia, and Bismarck had to pay his respects in an impossible attire-some of it borrowed for the occasion. The Princess also remembered the exact sum of money that delightful trip cost-that was reality, not a fictitious asset! I think she told me it was exactly one thousand Prussian thalers, an enormous sum in those far-distant frugal days.

How many persons of high station Princess Bismarck must have seen in her house, and from how many must she have received homage in the course of her long life! And yet in her tiny boudoir adjoining the drawing-room there was not a single memento of any of them. Every inch of space was wanted for those she loved and for the few-however humble their station-who were devoted and true to her husband. Gorgeous tankards, mugs, centre-pieces, and every other form of silver and gold plate poured into the house as offerings from the outside world during the latter years of her life. 
Among these was the costly dinner-service I have already alluded to. But not even on Prince Bismarck's birthday did I see a trace of any of these things on the dinner-table or about the house. For the Princess attached little value to articles of luxury, however costly, unless they were connected in her memory with some distinct trait of human kindness. This was the case with a small silvergilt goblet, its cover ornamented with wrought roses in enamel. It was a memento from an intimate friend of the family, long since dead, whom she had nursed through sickness. This gobletalthough almost insignificant as an ornament-had always a prominent place in the centre of the table.

Armorial bearings such as one meets with in princely establishments, and more often in those of lower station, were hardly ever seen in the Bismarck family. A handsome carved oak easy-chair, on the back of which the Bismarck crest was elaborately carved and painted, stood in the drawing-room. It was the gift of a millionaire, whose taste was not equal to his devotion to Prince Bismarck, which was above suspicion. It was on account of the latter that the chair could not well be put on one side. The Prince, however, never used it, and to the Princess it was an eyesore. She called it vulgar, as she did everything which was loud and pretentious. So much was I accustomed to simplicity throughout the house that I was quite surprised when one day I discovered that the writing-paper for the use of the visitors was watermarked with 
the full Bismarck crest and coat-of-arms. The paper and envelopes were otherwise quite plain, and I felt sure Princess Bismarck would not have allowed that watermark to be there-harmless as it was-if she had had the ordering of the paper. I found afterwards that this particular paper formed part of a large stock which some wealthy paper manufacturer had sent in an oaken chest as a birthday present-enough writing-material to last the whole family for a generation or two.

There was an old-fashioned stamp about many of the things in the house, some doubtless owing their continued existence to motives of economy; but this was by no means always the case. When it was a question of choosing between the best and an inferior kind, there was no hesitation, although Princess Bismarck had been brought up in a spirit of economy, and down to the last was ever ready to put it rigidly into practice. Thus all the rooms in the house were lighted by French moderator lamps, although they are very expensive to burn, and give a good deal of trouble to keep in order in comparison with modern petroleum ones, but she preferred the softer light of the old-fashioned moderator, and adhered to it always.

When I first came on a visit I was rather struck by the excellent quality of the tea served for breakfast, and one day I said as much to Princess Bismarck. She replied in her characteristic manner that there was nothing remarkable about it. It was merely a question of being willing 
to pay a good price for a good article. She had heard that people in England were very different in this to what they used to be, and were in the habit of drinking cheap tea costing less than two shillings per pound. At that price, she added, it was obviously impossible to get anything worth drinking. That was all that passed at the time, but some little while after, when I had returned to England, a big chest of fragrant China tea arrived from Hamburg with an indication on the cover that it was sent by order of Princess Bismarck. Nor was this the only occasion which showed that she remembered a visitor's appreciation of the good things of her household. When about to take my leave after a subsequent visit, she called me into her boudoir, and opening out a drawer, handed me a tin of tea. Before I had time to express my thanks she had brought out and handed me another tin. She checked my expressions of gratitude in her blunt, true-hearted manner with the words, "Never mind, take it, I am like that" ("Ich bin so").

Princess Bismarck's unceasing care for her family and her guests showed to what an extent a wife, a mother, a mistress of a household can sacrifice her own convenience in identifying herself with the wants and wishes of others. No general in command could survey a battlefield more completely than Princess Bismarck controlled a dinner-table. She was in supreme command and overlooked everything. There was at times something not far from 
heroic in this, seeing that she was often hardly able to keep awake. There she would sit, not touching a morsel. Yet in spite of her suffering from asthma -at times scarcely able to draw a breath-her eye was everywhere, controlling, ministering, seeing that everybody was attended to and satisfied. If the conversation at table turned on a fresh delicacy of the season, or some new dish, or the predilection expressed by a guest, the chances were that one or the other would make its appearance next day. Whilst at table she would whisper a few words to one of her servants to give a message to the cook to add some item to the very dinner in progress. I have heard her say, "Go and tell the chef to roast a couple of quails at once, and send them up." There had been something not quite to her liking in the preparation of those already served. Nor was it only from a desire to humour the taste of her husband that Princess Bismarck showed such vigilance in controlling the wheels of the domestic machinery. All her household, domestic servants included, were the objects of her constant solicitude. Her care for her guests may be said to have accompanied them after their departure, for she insisted that everyone on leaving should take a bottle of claret and a cold fowl for lunch or supper with him.

A look at Princess Bismarck was sufficient to show that she was a woman of unusual perspicacity. It has been said that her strong likes and dislikes now and then blunted this acute sense of hers, but 
of that I possess no direct knowledge. My experience, on the contrary, afforded me various indications of her clear discernment.

Prince Bismarck had somewhat of a partiality for Englishmen, Americans, and Russians. His wife reminded one of the student in Goethe's Faust who disliked the French but was ready to drink their wines. Princess Bismarck admired the literature of other countries, with which she was familiar, but at all times she preferred the company of her own countrymen. And of the latter an intelligent village apothecary to many a lion of Society. She frequently alluded to the elderly ladies I had met at Varzin in 1891 . One of them had a niece-an authoress. The Princess was proud of them; they were her own flesh and blood. She estimated people and things as she found them, and was averse to taking either on trust. She was suspicious of them as of tea at two shillings a pound. A rough exterior did not repel her so long as she believed the qualities beneath it were genuine.

The snob was her especial abomination. She was quite conversant with this unique, untranslatable English term, though she would use it in the sense of an adjective. Thus she would quietly dispose of someone whom others endowed with less acumen greatly admired by saying, "Don't you think $\mathrm{X}$. is very much snob?"

There was something about Princess Bismarck which now and then gave one the impression that she was not purely German by descent ; that there 
was a Slavonic mixture in her blood. This is well known to be the case with many of the Prussian noble families which come from the east banks of the Elbe. Her maiden name too, von Puttkamer, has a distinct Slavonic sound. And if this be more than a mere hypothesis, it would only be in accordance with Prince Bismarck's favourite dictum, that the most complete natures are those which unite the characteristics of two races more or less complementary to each other.

There can be no doubt that, like a musical instrument with an extensive register, Princess Bismarck was a woman of very strong feelings, be they inclined towards sympathy or antipathy. Love and hate struck deep as a well in her heart, intensities rarely shared by the Prince, upon whom every excess of feeling acted as an irritant. The late Count Hatzfeldt once told me that he was present one evening during the German march on Paris, when Bismarck received a letter from his wife in which she expressed the hope that he would not show the French any mercy. Bismarck turned to Count Hatzfeldt and said, "My wife will yet drive me to do the French a good turn."

On one occasion the Princess pointed in my presence to a picture hanging in the drawing-room of "The Cavalry Charge of Gravelotte," in which her son Herbert was severely wounded. Some wounded Frenchmen lay in the foreground, and she exclaimed, "Those rascals nearly killed my poor son." There was something in the tone of 
her voice as of subdued agony-of hatred. It was a note of passionate wailing, as of the aching of the heart-strings such as some mournful Russian songs recall. But even more characteristic was the expression of her face when of an evening she would sit for hours together watching her husband reading. There was a watchfulness, a concentration, a determination, an intensity in her gaze such as those deep-souled women must be capable of who figure in Turgenief's weird tales. It was all there in the fiery spirit of this pallid sick woman, watching every twitch of the eyelids of the husband she adored.

Her keen sense of humour held the balance in her mind between the extremes of passion and kindliness of heart. Few people could laugh more heartily than Princess Bismarck. Her smile was of that rare kind which illuminates a countenance with unlimited candle-power. She had a keen sense of the grotesque-the ridiculous. An idea she had imbibed was that English people are all millionaires, or at least very rich. She had heard from the Empress Frederick that English wealth was so great that the merchants of one English city alone possess more silver plate than half the Prussian aristocracy. Now the idea of mere wealth was not one to impress her. She was therefore all the more inclined to raillery, when anything told against a statement which she had previously accepted too readily, and which had it even been based on truth would not have called forth her admiration. 
The credulity of mankind came in for her sarcasm even when she herself afforded an object-lesson of its folly. Thus the discovery that the English are not all as wealthy as she had been led to believe aroused her derision.

The following incident was a source of surprise and amusement to her. Once when staying at Homburg -I think she told me it was in 1891 - a princely personage called upon her who had married into the English Royal Family. During the conversation which took place came a knock at the door, and an attendant entered the room with the change for a draft which the Princess had sent out to be cashed. Princess Bismarck ran her eye over the money to see that the amount was correct, and turning to her visitor apologised for the interruption, adding that to a man in his position it must needs appear dreadfully vulgar to be counting money.

"In my position," her visitor replied, "why, my dear Princess, I have not got a shilling in the world to call my own!" 


\section{CHAPTER XIII}

\section{BISMARCK'S EIGHTIETH BIRTHDAY}

\section{APRIL IST, I 895}

THE eightieth birthday of Prince Bismarck 1 became the occasion of an ovation the like of which has probably never been accorded to a public man in any country. The fête at Friedrichsruh itself was only the focus of what was practically a world-wide event; for Bismarck's birthday was simultaneously celebrated all over the world wherever Germans were to be found-except here and there in his own country. In Germany his enemies were apparently determined that the old proverb of the prophet and the land that gave him birth should not fall into desuetude if they could help it. For, incredible as it might well appear to a stranger, neither the German Reichstag nor the Berlin Town Council, as represented by a "compact majority," could bring themselves to send a congratulatory message to the Unifier of their country. They seemed to want to show the world, once more, with what unpromising 
materials the great artificer had done his work. What a legacy of envy, hatred, and malice he had had to paralyse, but was unable to destroy. He had united the Germans as a nation, apparently for all time to come, and yet they could not agree on one single day in the course of eighty years to do him united honour. One of the worthiest parliamentary figures of Germany, the venerable Rudolph von Benningsen, could not contain his indignation when the Reichstag declined to do honour to Prince Bismarck on his birthday. He rose from his seat with the words, "In our century he has not his equal." The President and the Vice-President of the Reichstag resigned in disgust. Even Frenchmen were found to express their surprise, and their appreciation of what Bismarck had done for his country. "The canopy of heaven were not lofty enough for us to have placed a man under who had rendered us such services," wrote Paul de Cassagnac on the morrow of Prince Bismarck's retirement. Germany in her best sons may stand at the head of the world as an ethical and intellectual force, but she is still far from being a great political nation in the sense in which England and France are such.

Bismarck, however, did not mind the slight put upon him; he even managed to turn the tables on his enemies by the neat wording of his answer to the telegram of the Emperor, in which His Majesty expressed his indignation at the vote of the Reichstag. He assured the Kaiser that the 
action of his opponents had become a source of special gratification to him by calling forth $\mathrm{His}$ Majesty's gracious words of sympathy.

Great was the rejoicing in Hamburg when on the evening of March 3 Ist an illumination took place in honour of Bismarck's birthday, such as no other town in the world except Venice could have arranged. Sixty-eight thousand gas-jets lit up the Lombard Bridge-Hamburg's Rialto. The whole town was reflected in a sea of light in the waters of the Alster basin, whilst thousands of rockets, let off to the accompaniment of cannon, spread sound and brilliance far afield.

Never again is the Saxon Forest likely to witness such a busy scene as Friedrichsruh presented on the morning of the ist April. The road from the railway station to Bismarck's residence was dotted with stalls like a fair, in which programmes, postcards, photographs, medals, flags, banners and other mementoes were sold by the thousand. Large wooden sheds, prettily decorated with furze, had been erected at the railway station and at the post office; at the former refreshments were served, the latter were for the convenience of the seventy journalists who had come from all parts to describe the proceedings, so that the whole world might read of them on the morrow. Thirty-five special trains brought a vast concourse of people, three of which, drawn by two locomotives apiece, were reserved for the deputation of German students. By command of Count Waldersee, the Governor 
of Altona, six military bands played alternately through the day in the village and in the park.

I met Count Henckel von Donnersmarck and Professor Lenbach in the park about eleven o'clock. The former had always been a faithful friend of the Prince, the latter had spent the early hours of the morning arranging the enormous collection of flowers which had arrived. Assisted by Bismarck's servants, he had grouped them tastefully in front of the house, so that when the Prince stepped out he found the grounds transformed into a garden of exotics, the South of Europe having contributed tons of tropical flowers for the occasion.

The Hamburg Senators, headed by the burgomaster of the city, comprised the first deputation to be received by Bismarck. It was about half-past eleven o'clock in the morning, and they were already assembled in the drawing-room when the Prince entered. As he came in he caught sight of a friend who had been a guest in his house on several previous occasions. Bismarck walked up to him, shook hands, and said, "Herr X., I am glad to see you, but I feel guilty as a host that you are not staying under my roof." This was a stray instance which came under my notice of that delicacy of feeling which characterised this extraordinary man at all times, even at such a moment, when it would only have been human if he had had no thought, much less kind words, to spare for outsiders.

The worthy Senators had brought a large bronze 
medal, modelled by Professor Schaper, as their birthday offering. They had scarcely withdrawn when the deputation of the German Universities was ushered into the Prince's presence. It consisted of the rector, or official figurehead, of every German University and polytechnicum-twentyeight representatives in all. I stood behind the Prince as the deputation spread out in half-moon shape immediately in front of him, and the spokesman, Professor Pfleiderer, of Berlin, a most sympathetic figure, advanced a step out of the centre, parchment in hand, to address the Prince. Dr. Schweninger was at Bismarck's side, peering anxiously into his face as if to seize in time the slightest indication of over-exertion during what might well have been considered an ordeal to a man of his age.

Never before in the history of Germany had an honour been paid to potentate or subject like that conveyed by this united homage of the academic chiefs of the country.* The sight of

* Prince Bismarck was probably the only statesman who ever attained the high distinction of being a doctor in each of the German academical faculties. On July 21 st, 1876 , the University of Halle made him a Doctor of Philosophy. On March I8th, I885, the University of Göttingen nominated him a Doctor of Law ; and on April Ist, 1885, the old statesman's birthday, the University of Erlangen conferred the same legal dignity upon him. On the same day of the same year the University of Tübingen raised him to the distinction of a Doctor of Political Science (Political Economy). In November, 1888, the University of Giessen surpassed all her academical sisters by proclaiming him, honoris causa, a Doctor of Theology. On July 16th, 1896, the University of Jena made him a "Sixfold Doctor" by conferring upon him its degree of Doctor of Medicine. 


\section{BISMARCK'S EIGHTIETH BIRTHDAY}

the erect figure of the old Chancellor in his darkblue uniform, surrounded by these distinguished representatives of German learning, decked in their scarlet robes and gold chain of office, was one to impress itself on memory and imagination. It recalled some gorgeous picture of Paul Veronese, drawn from the annals of Venice.

Bismarck had often said that politics spoil a man's character. Thus politicians might revile him, but the homage of twenty-eight German high schools stood on a different plane to that of mere politics. This distinction would scarcely have been bestowed upon a successful politician as such, or even upon a great soldier, however victorious. Bismarck had often accused German professors of being a wrongheaded lot; but no one appreciated more than he the lofty spirit which animates the best of the German academical world. And here they stood before him. Many of them were men of world-wide reputation. Each of them was an unquestioned autocrat within the aula of his Alma-Mater. A little but very important world in itself, in which the vulgar values of the crowd have no currency. Tradition is law, and it is of the noblest: the pursuit of truth. Priests in the tabernacle, in charge of the sacred vessels to be kept bright and pure and handed on from one generation to the otherfor the benefit of the whole world, though outside "The grimy crowd might puke and push."

Yes, the German Universities form a world in themselves, and their chiefs have come forth from 
it for this rare occasion. It is their supreme task, in addition to the cultivation of knowledge, to cherish, to foster, and to spread those moral influences which Bismarck loved to call the imponderable assets of a nation; those immortal values for the inviolability of which a people, if it is worthy to live, must, when the occasion arises, be prepared to stake its existence. The idea of National Unity was one of these. It was nurtured at the Universities through periods in which many of the German Courts-dead to every higher interest-vied in coarse imitation of the licentiousness of Versailles, and found ready imitators in their turn among the aristocracy and the people. But whatever the evil temper of the hour, it rarely was able to affect the spirit which prevailed at the Universities. They were the legendary guardians of the Ideal Values, the "Immortalities" of the nation. As such their importance is as great to-day as ever. For they are largely that to Germany which is represented by the clergy and the pulpit in other countries; and should the example of gambling, of luxury, idleness, and riotous living imported from abroad affect the Army; should the frugality which was once the pride of its loftier spirits become its shame, and hard work which was its guerdon become a reproach-then Germany will indeed have to look to her Universities, if a Jena is to be averted. Should the honour, the self-respect of the nation be threatened in other quarters and the patience of the "best" and 
noblest be tried too severely, it will then be from the Universities that a thunderous, unmistakable " Halt! it is enough!" will burst forth.

It is not surprising that the heads of these responsible institutions should occupy very exceptional positions in German life. German rectors are not easily to be touched in their independence by the whim of a sovereign or the trumpery passion of the crowd; ready, in fact, to speak out and face the displeasure even of a throne in the defence of what they hold high in thought and conduct. Few positions in this world equal that of a rector of a German University in public respect, dignity, and independence. It is one beyond the reach of vulgar ambition. Even the donor of millions would aspire to it in vain, since it is rigidly reserved for those who have devoted their lives to academical pursuits. Bismarck was well aware of all this. Hence his high appreciation of the homage tendered unto him.

These men had come to thank him for ideal things; not for having increased the acreage and the revenues of the country, not because he had been the means of gorging the Prussian Eagle with foreign plunder. No; freedom to live and to breathe a self-respecting national life: this was the prize which they valued. True to the words of Pfizer, inscribed on the walls of the old German Reichstag: "The First Right of a Nation is to exist and be recognised as such." This right Bismarck had secured for Germany; and under 
the auspices of grand King William he had brought back as a priceless possession an old site of German learning - the University of Strassburg, which had been ruthlessly filched by the foreigner, together with the venerable Gothic cathedral. The academic world gloried in this deed of righteous restitution.

They had also come to honour in the statesman the lofty intellect, the sobriety, the veracity-ever the rare qualities of the elite, which go to form a lodestar to the many in the great crises of a nation's existence. Such was the meaning of the concluding words of Professor Pfleiderer :-

"Far beyond the reach of the affairs of State your powerful personality has impressed itself indelibly upon the intellectual life of Germany. A master of the German tongue as spoken and written, you are entitled to a place of honour in our literary annals. The shining example of your deeds has whetted our nation's appreciation for the sense of historical reality. The lucidity and range of your political perception have enlarged the scope of our national interests, and added to our conception of life. The lofty earnestness with which you have endeavoured to warn the German people of the dangers of success has given fresh stimulus to the conviction that the deepest sources of control of the realities of life flow from the moral force of faith."

Pride and delight at being present at such a scene were visible on the faces of all. There was no trace of obsequiousness, much less an attempt at rhetorical display. The occasion stood above the tricks of the histrion. It was as of

"A tide too full for sound or foam." 
Prince Bismarck thanked the deputation for their address in a short speech, in the course of which he referred to the enmity of which he had been so constant an object as a proof that the ideas for which he had battled so long were still to the fore, and, as he hoped, would continue to live on for the welfare of his country. The professors were delighted with Bismarck's simple words, spoken as they were in a tone of social intercourse as between friends, and they gladly accepted his invitation to stay to lunch. Tables were set in two rooms, one adjoining the dining-room, and about fifty persons sat down.

We had not been long seated before the deputation of German students began to assemble in the park in front of the dining-room windows. It was about half-past one o'clock. The door leading on to the terrace was thrown open, and Prince Bismarck stepped out, followed by his family and his guests, among whom were several officers of the Seydlitz Cuirassiers, Count Vitzthum (the envoy of the King of Saxony), and many others; but, most conspicuous of all, the University chiefs. They had donned their quaint academic barrets. A sound struck the ear as of the waves retreating over the shingly shore-not the angry roar of the storm, but the caressing play of the waters sighing over the pebbles on a bright summer's day. It was the first utterance of joyful surprise of the closely packed crowd in front of us as Bismarck appeared before them. As far as the eye could 
reach through the still leafless, tree-grown space stood one mass of German students in all the bright colours of their respective corps-over four thousand of them. Their swords gleam aloft as their clangour strikes the ear, and the eagleemblazoned banners are waved on high to the cheers-the "hurrahs"- that greet the Prince. These, in their turn, are taken up and re-echoed in the distance, outside the boundary of the park, where a dense black line of spectators is visible. It is a thrilling sight, an even more moving sound, when all of a sudden the Saxon Forest is hushed in silence. Bismarck's steel helmet glitters in the sun as he leans over the parapet and faces those who have never ceased to be near his heart throughout his long career; for the sight of German students always brought back the happiest recollections of his life.

Two years ago it was an impressive memory of the past which presented itself here on this very spot when Bismarck welcomed the SchleswigHolstein veterans. This time it is a picture of the future of the German Empire which strikes home, as a manly voice rings out from the crowd and lends passionate expression to the sentiments of grateful devotion which animate those who are to represent German thought and action in days to come.

These students come from all parts of Germany -from the Baltic to the Alps-their number increasing, strange to say, in proportion to the distance of their University from Berlin. This is to 


\section{BISMARCK'S EIGHTIETH BIRTHDAY}

say that the majority come from parts which thirty years ago were arrayed against Prussia in open warfare; thus from Leipsic, Munich, Giessen, and Göttingen-strong testimony in itself of the beneficent and conciliatory result of Bismarck's work. They look a quaint, angular crowd in the eyes of the carefully dressed man of fashion, and I fear there is a boisterous roughness among them. But such as they are it would be impossible to find the superior of the best of them all the world over, for they carry with them the unsullied ideals of a young and great people; they are imbued with the enthusiasm of youth, something nobler and better than our average everyday measure of profit and loss. And it is to this that Bismarck appeals in addressing them. Words of wisdom issue from his lips, clothed in quaint imagery drawn from the woods, the river, the plain, and the life that abounds there. He speaks deliberately without effort, unpremeditatedly coining his ideas as he proceeds-but irresistibly-as a force of nature which spends itself-patrice inserviendo consumor - as of old.

He tells of the sacrifices of the past, of their having been unavoidable; how they have taught lessons for conduct in the future which are embodied in rallying firmly to empire and unity. To retain what has been won, not to crave constantly for more, is the aim to be kept in view. He holds it to be a bright characteristic of the Germanthat he seeks gratification in the consciousness of 
his own worth, and does not feel impelled to grasp after hegemony and privilege at the cost of others ; not to a mere conquest in the Napoleonic spirit does the Teuton tend. Stout and true hearts shall make a nation's strength and glory-not an unholy lust of endless possession, for there are things which a nation's honour forbids.

Cheers rend the air to the clanging of swords, and the military band strikes up the National Anthem, "Heil Dir im Siegeskranz." The seniors come on to the balcony, on which stands the gift subscribed for by German students throughout the country: an obelisk in onyx, surmounted by an eagle in silver. A cask of Munich beer is hidden in its base, from which the first glass is handed to Bismarck. This he empties to the welfare of academic Germany, starting himself the refrain of the old student's song, "Vivat Academia, Vivat membrum quodlibet."

Bismarck's life had been rich indeed in moments of triumph, in all of which he had retained that naive simplicity which only an unspoilt heart can confer. Here on his eightieth birthday, when the song specially written for the occasion and sung by thousands of voices to the melody of Theodor Körner's "Du Schwerdt an meiner Linken" resounded throughout the forest, he must indeed have felt the thrill of certitude of his own immortality. In the words of Faust :-

"The traces of my days on earth

Shall not be effaced in æons of time." 


\section{BISMARCK'S EIGHTIETH BIRTHDAY}

Verily it was one of those rare moments in which the spectator fancies he can feel the very pulse of a whole nation beating. Nearly two thousand years of human history have played round about these northern forests since Tacitus penned his noble tribute to German faith and valour. Generations pass away, but the soul of a nation is immortal. Here in this surging sea of Germany's youth still liveth the soul of the Teuton race. It is to be hoped that they may be fashioned of the stern stuff of their forefathers, not of such as sell their swords for pelf, but of those who in time to come, in the great crises of life, whether in the study, the forum, or the field of battle, shall be true to Bismarck's words at Jena :-

"I act according to my conscience and my sense of duty, without asking what consequences may arise therefrom for myself. These are quite indifferent to me."

As the crowd swayed to and fro, and the last sound of the thousands of voices died away, it was as of an old world vanishing, as if, although but early spring, the earth were already covered with flowers.

The Prince, accompanied by Dr. Schweninger and Count Herbert, descended among the crowd, which left an open space as he walked up and addressed a few kind words to the students on his path. On returning to the balcony, Prince Bismarck took a last view of his youthful admirers as they filed past singing "The Watch on the 
Rhine" and other national songs. He threw the flowers which were on the parapet beside him down to the students, among whom a good-natured struggle ensued for their possession.

I had undertaken as part of other duties at the time to send a telegraphic report of the day's proceedings to the New York Herald, and this kept me for several hours at the post office. ${ }^{*}$ I thus lost my chance of being present at the family dinner, as well as at the torchlight procession, which took place soon afterwards. My only memento of the former is a menu card which Count Herbert gave me when I arrived late and found some supper ready laid in the dining-room.

Bismarck sat in his accustomed sofa-seat placidly reading the paper in the corner of the drawing-room, surrounded by his family and a few visitors. Among these was his aged sister Frau von Arnim, to whom, as "Liebe Malvine," many letters of thought and feeling were addressed by him in other days. A stately lady; even in old age an air of dignity and refinement very marked in the remnants of her good looks.

Telegrams were being brought in continually.

* The improvised building in the post office contained comfortable desks and seats for over seventy journalists. The way the telegraphic service was managed, the accuracy, promptitude, and politeness with which long telegrams in half a dozen different languages were dealt with, reflected the highest credit upon the German postal authorities. The deciphering of foreign languages could probably not have been dealt with anywhere in the world outside Germany so successfully. Many of the telegraph clerks were quite familiar with English and French. 


\section{BISMARCK'S EIGHTIETH BIRTHDAY}

They came during the evening in such batches that it was as much as Count Rantzau and Count Herbert could do to open and read them. There were upwards of ten thousand of them-quite formidable blocks of telegraphic sheets. Those from royal personages took up extra time to attend to, for etiquette prescribes an immediate acknowledgment. A cordial message from the Empress Frederick was among these; also one from the Emperor of Austria, the present King of England, and the King of Roumania. The latter always made it a point to remember Bismarck's birthday, although it is said that now and then in days gone by Bismarck had dealt rather unceremoniously with Roumania. Among the telegrams replied to at once was, as two years ago, one from some school children in England.

To a visitor who expressed anxiety with regard to the fatigue of the day Bismarck replied, "Yes, I think I might almost look back with longing to the quiet life of a full-blown minister."

Late at night I looked in on Dr. Chrysander in his sanctum. Where two years ago packets of letters had strewn the floor there were now large wicker baskets and even barrels filled with them. They conveyed some idea of the meaning of a million or even half a million, quantities so often discussed and so rarely realised; for Dr. Chrysander told me that letters and post-cards received could not be far short of half a million. But the following are the official figures of the German Postmaster-General 
for the postal and telegraphic service at Friedrichsruh during the week which included Prince Bismarck's eightieth birthday.

The staff of the little post and telegraphic office at Friedrichsruh was raised to the strength of about thirty various officials for the birthday week, while the telegraphists had at their disposal five direct wires to Hamburg and four to Berlin. From March 25th to April ist the number of telegrams received gradually rose from 102 to 4,I22 with 128,266 words, while per contra on the last-named day there were despatched 606 messages, totalling 57,814 words. From March 25th to April 2nd the total number of telegrams received and forwarded was I I,475, aggregating 453,000 words. The postal service, too, was equally enormous, the Prince having received during his birthday week 979 ordinary parcels, 265 registered ditto, 995 registered letters, and about 450,000 ordinary letters and bookpost consignments.

A photographer who had taken up his abode in the village in order to "snapshot" the Prince did a large business in Bismarck portraits mounted in oak of the Saxon Forest, of which he bought an amount equal to a whole shipload of timber from Prince Bismarck's Forest Administration.

This was the last occasion on which I formed one of a large house-party at Friedrichsruh, for my subsequent visits took place when Prince Bismarck was alone with his family. A plain luncheon menu in my possession dated April 3 rd, 1895 , marks the last meal at which I was present. On the back of the card I jotted down at the time the different topics of conversation broached by Prince Bismarck 
236 BISMARCK'S EIGHTIETH BIRTHDAY

during lunch. Several of them I was only able to note down by a single word, and of some of these the connecting idea has since escaped my memory. But sufficient remains to enable me to recall his exuberant versatility and brightness on that occasion.

My first entry shows that Bismarck indulged in a fling at his old enemies, the Social Democrats, for he said, "I wish it were possible for them to put their ideas to the test of practice and we could see the result." The next topic was the so-called "Umsturz Vorlage," which is bracketed with the words "Eau bénite." This was a favourite expression of Bismarck's to denote the sinister activity of the Ultramontane party, particularly in educational affairs. Another favourite epithet of his was "Jésuite à courte robe." He applied it to politicians who combined the pursuit of worldly ambition with hierarchic intrigue. The next entry is "Gambetta Schlawe," reminding me that Gambetta's projected. visit to Varzin was mentioned. The word "Altreichs-Kanzler" recalls Bismarck's remark that he thought it a silly definition of him in his retirement. My longest entry refers to the pièce de résistance of the occasion.

Someone present mentioned a statement attributed to Mr. Gladstone-that the only sleepless night he had cver passed was caused by worrying whether he would be successful in felling a tree on the morrow which he had started to cut down in the evening. Bismarck said: "If it be true that the 
felling of a tree was the only anxiety that ever caused Gladstone a sleepless night, I do not envy him ; for it would not reflect much credit upon his heart." A visitor playfully took Mr. Gladstone's part, and said "that though Mr. Gladstone might not be particularly tender-hearted, he possessed "principles.'" These guided his conduct and formed the basis of his disapproval of Lord Beaconsfield's morality and also of much in Bismarck's own career.

Bismarck was amused, and said that "when you disapprove of the actions of others and want to have your own way, it is very convenient to have principles which can be made to fit in with and justify your conduct." He feared that he himself had been unfortunate in this respect, inasmuch as he had never stopped to weigh whether his actions were in harmony with a code of principles. $\mathrm{He}$ would not have known how to set about it. He had always been content to feel that his conduct must be in accordance with what his instincts told him constituted his duty. If he had attempted to regulate his action by any other course, it would have left him a prey to all sorts of sophistries. $\mathrm{He}$ once knew a man who had very convenient principles which he used in a very practical fashion. It was one of the Frankfort Rothschilds. When the great financier was in doubt on any business matter he would consult his head clerk in the following manner: "Herr Meyer, pray tell me, what are my principles to-day with regard to 


\section{BISMARCK'S EIGHTIE'TH BIRTHDAY}

American hides?" Bismarck thought that what people often style their principles are simply lifeless formulæ which serve to narrow the scope of their free volition and thus detract from the range of their individuality; hence the value he attached to independent decision free from cut-and-dried principle.

A Russian story was told of a Prince Galitzin who had asked his chef to draw out a recherché menu for a diplomatic dinner and submit it to him. The chef did as he was bidden, but in perusing it his master was surprised to find that it contained a number of gross mistakes in spelling. Prince Galitzin drew his chef's attention to them, saying that such mistakes would be a disgrace to the house when entertaining such important guests as the ambassadors of the Great Powers. The chef, an Italian, whose name was Ingano, replied, "Mon Prince, vous demandez de moi un menu bien écrit! Parbleu! si je savais l'orthographie je serais déjà longtemps devenu ministre dans mon pays."

When the papers were brought in Bismarck looked at them, and citing some gathering of ladies at which his health had been proposed, he said, "Well, in my old days I am evidently getting into favour with the fair sex."

"Why, Durchlaucht," Lenbach put in, "you have always been a favourite with the ladies!"

"Oh no," Bismarck replied, and his voice dropped to a whisper, "only with my wife."

* * * * * *


I saw Prince Bismarck once more in the course of the same year, for I came again to Friedrichsruh on the i 8 th July. Dr. Schweninger was in Norway, and rumours had got abroad that Bismarck was suffering from a complication of ailments; but I found him looking remarkably well and in good spirits. Count Rantzau told me that his father-inlaw had received thirty-eight different deputations in person since his birthday. After such an ordeal his good appearance bore indeed strong testimony to his unimpaired vitality. The Prince told me that his only trouble had been, and still was, that same persistent neuralgic face-ache which he had suffered from for years past, that it troubled him more particularly at night. "The muscles of my face," he said, "are like a set of electric bells-once put in motion they will not stop ringing. Schweninger wants me to go to Gastein, but I intend to stay here with my home comforts right through the summer. Some people suggest my going to Egypt," he added, with a droll smile, "but my reason for declining to do so is that I would rather be buried here than live out there."

The English elections and the assassination of the Bulgarian statesman, Stambulow, formed the news of the day. Bismarck appeared to have followed the former rather closely, and said that he regretted to hear that the worries of office had apparently put too great a strain on Lord Rosebery's health and that he hoped he would soon be himself again. He was very sorry for the sad fate 
of Stambulow, who, he said, was a man of great force of character. Bismarck added he did not believe that the assassination was instigated by Russia, although it was well known that the Russian rouble was a staple commodity ("le rouble roule") throughout the Balkans. He thought that the crime was probably planned by some Macedonian, or other local revolutionary committee. "You must know that the pistol and the dagger are current political arguments in those parts," he added.

I asked him whether he had read the gruesome detail that Stambulow's hand had been cut off and preserved in a jar with spirits of wine. Bismarck turned round sharply, as he often did when about to say something pointed-this time it was a grim joke-and said, "Don't you believe it!"

"But," I replied, "it is the papers."

"Ah!" he added, "that is all very well. But, believe me, if they had got his hand in spirits of wine, they would soon drink the alcohol off."

This was not the only occasion on which Bismarck expressed in my hearing a poor opinion of the population of the Balkan States. $\mathrm{He}$ had little sympathy with that queer Macédoine de races heterogènes, almost as little as he had for the modern Greeks, who embodied in his mind all the sophistry, trickery, and mendacity of modern international Liberalism in general. 


\section{CHAPTER XIV}

\section{VISIT TO FRIEDRICHSRUH}

JUNE, $1896^{*}$

GEVERAL of my previous visits to Prince $S$ Bismarck had coincided with the anniversary of some important event in his life. This time it was exactly a quarter of a century to the day since the old Emperor William drew up and signed the letter in which he announced his intention of presenting the estate of Friedrichsruh to his faithful Chancellor.

One of Lenbach's masterly portraits of his hero looked down from the wall as I was shown into the morning-room. A curious engraving of Bismarck, inscribed with Chinese characters-just received presumably - "Made in China," occupied a chair. Close by stood the elaborate oak timepiece-a grandfather's clock on a very large scale-which I had often admired before. Several busts of

* The expressions of opinion attributed to Prince Bismarck in this chapter were taken down by me from memory immediately after my visit. Most of them appeared in print 12th July, 1896, and were emphatically endorsed by the leading Bismarck organs at the time as giving an exact representation of the Prince's ideas. Thus they no longer stand on my sole responsibility. 
Bismarck were stowed away in odd corners, as if to make room for the more impersonal offerings with which the tables and cheffoniers were crowded, notwithstanding that a large number of presents had from time to time already been sent to the museum at Schoenhausen.

The Prince's grandsons, the young Rantzaus, were in the room with their tutor grinding their way through the Greek Grammar, and seemed not over sorry to be interrupted by my coming.

"Grosspapa is not about yet," said the eldest, and the tutor added that His Highness had not enjoyed a good night's rest, and that lunch had been put off a little in consequence. However, it was not long before the doors were thrown open, menservants passed to and fro, and Dr. Chrysander appeared, carrying an important-looking portfolio. We were informed that Prince Bismarck was already in the drawing-room and that lunch was served.

It was nearly a year since I had seen Prince Bismarck, but he did not appear to have aged in the interval. His complexion was of the same healthy hue, and his large blue eyes flashed their old fire. Only the neuralgia, from which he had long suffered, seemed to have become more acute, for I noticed that he now and then held his hand to his left cheek as if in pain. This, however, was noi for long; his bright humour quickly returned, and with it his interest and participation in every topic of conversation. He asked me where I had come from. I told him I had been 
staying a few days in Dresden; that I hardly knew the town again, so much had it changed within recent years. And I instanced the erection of the magnificent Central Railway Station in the Altstadt at a cost of $70,000,000$ marks. Bismarck did not seem at all impressed with this indication of material prosperity in a part of Germany, formerly associated with petty ideas and poverty. It was evidently news to him. He said he thought such a costly station was a great piece of extravagance.* "What wine are we to drink? What do you say to Dürkheimer?"

"Yes, let it be Dürkheimer by all means," I chimed in. I remembered when at school having been to Dürkheim on a walking tour-a pretty, idyllic spot.

"Dürkheim is a wine of the Palatinate," said Bismarck, "and its wines, although rather potent, are excellent. . Formerly I knew little about them, although I always knew something about wines in general. But now that such a large assortment of fine wines has been sent to me as presents I need no longer exercise my own judgment, and I fancy that my friends reap the benefit of the change. When I was in Frankfurt we used to drink Baden wines, more particularly Affenthaler and Markgraefler. They were very cheap in those

* In connection with this remark by Bismarck in June, 1896 , it is interesting to note that the unsatisfactory state of the Saxon finances in the year 1902 was currently attributed to the excessive sums spent during previous years on railways, notably on elaborate railway stations. 
days. A first-rate wine only cost a florin a bottle, and the average table wine was something like eighteen florins the hundred litres, about twelve kreuzers* a bottle. I used to smoke some cigars, too, which cost the same amount per thousand (about one kreuzer apiece), but only one a day," the Prince added, with a sly twinkle. He said something about Eastern potentates having a skeleton at their feasts to remind them that they were mortal, the application of which I failed to catch. I fancy he meant to convey that certain dangerous ventures-such as smoking bad cigarsmust not be repeated too often!

Somebody made the remark that we travel to excess nowadays, and that the nervous system has to pay for it in the end. Schweninger, the Prince's doctor; for instance, spends the greater part of his life in the railway cars.

"Yes, Schweninger indeed," Bismarck put in, "but he, you know, was born a rocket."

The transition from the topic of travelling to that of the different countries to be visited and their political troubles is a natural one. We soon got, by easy stages, from Germany, England, to Crete, Greece, Armenia, Egypt, as far away as the Cape of Good Hope, the South African Republic. We even touched China in the person of one of her great men; the excellent Dürkheimer-the long pipe and a fragrant cigar keeping us steadfast company all the way.

* Twelve kreuzers are equal to about $4 d$. in English money. 
England and Germany: their present and future affinities and antagonisms-a big topic for a luncheon table, and for the moment it was a delicate one. The aggressive German view was constantly kept before the public by Prince Bismarck's favoured organ, the Hamburger Nachrichten, which in its general drift might have been taken to represent his views (and more or less those of the enormous number of Germans who blindly accepted Prince Bismarck's dictum on such questions), as he did not mind them being made public. But there was always a vital difference between Prince Bismarck's personal views on foreign political questions and their rendering by German newspapers; between their passionate and, at times, even acrimonious tone and his dispassionate estimate of men and things. Thus while his journalistic organs might rave about the duplicity of English politics and the mendacity of the English Press, Bismarck himself remained impassive. $\mathrm{He}$ deprecated Germany getting too excited over questions which only remotely affect German interests. He might, perhaps, indulge in a caustic remark about an English, or, as the case might be, a German public man, but, as far as the two countries were concerned, he was opposed to any undue swing of the pendulum. "Not too effusive, not too abusive" was his keynote.

Somebody mentioned a recent imperial utterance that "blood is thicker than water."

"Yes, perhaps it is," rejoined Bismarck. "In 
every case blood is a glutinous fluid. But I do not remember that blood relationship has ever robbed quarrels of their bitterness. History tells us that no wars are so ferocious in their character as those waged between people of the same race-witness the animosity displayed in civil wars."

I mentioned that there was a widespread idea in England-although one probably not shared by many persons in responsible positions-that what our newspapers call "German intrigues" were at the bottom of the Transvaal imbroglio; that before leaving home I had received a letter from a very influential personage in England to that effect. I added that I had since spoken to a number of leading journalists and politicians in Berlin, among the latter to Herr von Benningsen, Prince Carolath, Professor Hans Delbrück, and others, and that they, one and all, had ridiculed the idea. Opinions on the telegram of the German Emperor to President Krüger had indeed varied with regard to its judiciousness, but no one I had met in Berlin or elsewhere had had anything to say against the sentiments it expressed.

Without expressing an opinion on the opportuneness of the imperial message, Prince; Bismarck said, "The Emperor's telegram might with peculiar fitness and decency have been sent to President Krüger by the British Government itself."

Somebody thereupon said he had recently met a representative American who had assured him that a strong current of public opinion existed in 
the New England States among the clergy and the teaching world which enthusiastically approved President Krüger. These Americans were indignant at the various attempts that had been made to intimidate him and to minimise his generous treatment of the Johannesburg prisoners.

"I do not think that President Krüger is in want of any assistance, German or any other," Bismarck replied in his quiet, convincing way. "The Jameson Raid was a clear case of attempted burglary or piracy (Seeräuberei). And should the worst come to the worst, the Boers, who are men of stalwart physique, phlegmatic temperament, and good shots into the bargain, may, I think, be relied upon to defend their independence and give a good account of their enemies."

To the remark that President Krïger had hitherto got the better of his opponents, the Prince added, "That was not very difficult, considering their blunders ... . and the clearness of President Krüger's case."

Prince Bismarck was familiar with recent South African events as well as with their antecedents, and was convinced that Mr. Rhodes was at the bottom of the Jameson Raid. $\mathrm{He}$ asked me whether Rhodes was a Jew. I replied that I had heard he was the son of an English parson. I gained the impression that in Bismarck's opinion Mr. Rhodes was an adroit exchange manipulator whose methods comprised bribery and corruption on a colossal scale. Bismarck 
thought that the attitude of the British Government towards Rhodes laid it open to the suspicion either of complicity with or connivance at the Raid, or at least of being afraid of its originator. The Prince was amused at Rhodes being acrepted as the champion of "British Imperialism." $\mathrm{He}$ had heard of that astute gentleman having contributed a cheque of $£ \mathrm{I}$ o,000 not so many years previously to a political party which was openly accused by a majority of Englishmen as aiming at the dismemberment of the British Empire.

With regard to the Jameson Raid, what struck Bismarck next to its criminality was the abject cowardice shown by the raiders when brought to bay. It was this cowardice which caused him to liken them to a pack of house-breakers. He was tolerably familiar with the history of English filibustering in the Spanish Main, and did not conceal a certain admiration for the dare-devil exploits of other days, even though they might not have always been in accordance with the law of nations. Bismarck held that desperate courage covers a multitude of sins, and he could even understand the rough popular sentiment which finds something to admire in the horse-thief or the footpad "dying game." But it was new to him to find Englishmen, who, whatever their shortcomings, had always been credited with physical courage-entering upon such an indefensible undertaking as the Jameson Raid-only to surrender 
after the first brush with the enemy on the humiliating condition of their lives being spared. But it fairly surprised him that the Jameson Raid had been glorified as a deed of heroism by an English poet holding a recognised position as Laureate, whose ode, he had heard, was nightly applauded by thousands in a London music-hall. I told him that there were many in England who shared his surprise; that several distinguished British officers had written to the papers protesting against the glorification of the conduct of those among the raiders who had formerly been in the British Army, much less their being identified with its spirit or traditions.

Bismarck's sympathy with the Boers was essentially a personal matter. It was first of all that he held the Jameson Raid to be an odious and cowardly crime, and secondly, that his leanings naturally inclined towards an agricultural people of Germanic race jealous of its own independence which was menaced. It seemed to afford him a certain satisfaction that his present status as a private gentleman enabled him to lend expression to his feelings untrammelled by the responsibilities of office. He held that Germany had become politically hoffähig,-that is to say, the individual German is socially and politically on a par with the individual of other nations, and thus Germans are at liberty to claim those social privileges which others have arrogated to themselves for generations past. Hence he saw no reason why he should not give free expression to his 
sympathy with the Boers in the same way as English and Frenchmen and others had never put a muzzle on their sympathies with Poles, Hungarians, Greeks, Bulgarians, Armenians, and other nationalities "rightly struggling to be free." Had Bismarck, however, still been in power he would not have allowed his personal leanings to have swayed his political action in this remote matter, any more than he ever did in other questions. He would never have encouraged the Boers to wage war against the British Empire, for he was too much of a "realistic" politician to think the chances of victory would be on their side. Even if it had been in Germany's power to assist the Boers, Bismarck did not think it would have been in her interest to provoke a conflict between England and Germany by endeavouring to do so. Whether he felt attracted towards England or was repelled by her attitude towards Germany, whether he admired her policy or felt constrained to condemn it, all this had absolutely no influence on the principle which was clear to him as embodying Germany's attitude towards England - and from which he never swerved-namely, that nothing imaginable ought to lead to a conflict between England and Germany-that it would even be a misfortune for Germany should England's position in the world be seriously threatened. Thus although he sympathised personally with the Boers as with men who had been unjustifiably attacked and their independence menaced by the actions of a cowardly 
crew of adventurers, he would never have sent President Krüger a congratulatory telegram. His calm judgment would have told him that it might encourage the Boers to build on German assistance, and this would be rendering them a disservice, as indeed the Emperor's telegram did; for in its consequences it sounded the knell of their independence, as we know now.

The name of $\mathrm{Mr}$. Chamberlain was mentioned in connection with South African affairs. Prince Bismarck's countenance darkened as he muttered the words, "A wild youth" ("ein wilder Junge").

The conversation then turned towards other matters. I asked the Prince whether he thought that Germany, as I had heard it asserted, had, at the instance of Italy, urged the British Government to undertake the conquest of the Soudan. To this he replied in the negative. He was unchanged in his opinion, so often expressed, that Germany has little concern in these matters. The straightforward way in which Bismarck added that the English had established order in Egypt would have convinced me, if I had needed conviction, that, whatever his opinion might be on particular political issues, he was free from the petty dislike of England so often imputed to him.

Referring to Turkish affairs, which at that moment were supposed to be in a more than usually critical condition owing to the Armenian troubles, the Prince said-

"What the Sultan needs are good servants, and, 
above all, determination. Turkey has gone through more severe crises than the present one; but, of course, you require exceptional qualities to cope with exceptional difficulties."

The mere mention of the Greeks produced an impatient gesture, which found interpretation in the words, "Græca non leguntur." As much as to say, "I don't want to hear or to say anything about them." And "As for Crete, I can assure you," Bismarck said, "that I take less interest in that island than in any little mound in my garden. The Cretans are, I believe, very lightly taxed, and under normal conditions should be far better off under the Turks than they could possibly be by belonging to Greece."

Whilst we were still at table a telegram was brought in. Bismarck, after looking at it, said that Li Hung Chang was coming to Friedrichsruh next day. "A great personage" ("Ein Grosses Thier"), he added archly. Whilst treating of great personages I may avail myself of the opportunity of denying once more the truth of the story that Prince Bismarck had ever likened Lord Salisbury to a lath of wood painted to look like iron. On the contrary, he held a high opinion of the English statesman, and this favourable opinion had even increased of late years. He thought that Lord Salisbury had grown with the responsibilities thrust upon him by his arduous position.

On taking my leave, the Prince said, "Come again soon, and we will drink a bottle of good 
Rhine wine together." It was the last time I ever saw him alive.

From Friedrichsruh I went back to England, and thence in the following month to Constantinople as special correspondent of the New York Herald, where I remained until the middle of the month of October. The day before I left the Sultan sent word that he wished to see me. I accordingly went up to the Yildiz Palace, and had an audience with His Imperial Majesty, his Second Secretary, Izzet Bey, being present as interpreter. The Sultan said he had heard that I was acquainted with Prince Bismarck, and he therefore wished me to take a present to the Prince, and to tell him how much he admired his lofty character. The Sultan hoped the Prince would always retain a kindly feeling for Turkey and for him personally. The Osmanli (the Turks) held the distinguished Germans who from time to time had served Turkey in grateful remembrance, and more particularly they remembered with pride that the illustrious FieldMarshal Moltke had once been among them.* It was to commemorate this that His Majesty had specially caused a portrait of Sultan Mahmud to be painted on a china plate in the imperial porcelain factory at Yildiz, which, together with a pair of beautiful china vases, he desired I should take as a present to the Prince. This I promised

* Sultan Mahmud reigned at the time Moltke was in Turkey (1835-9) planning the reorganisation of the Turkish Army. 
to do, and accordingly took the case in which they were carefully packed with me on leaving Constantinople next day. I brought it safely as far as Berlin, whence I wrote to Count Rantzau asking permission to come to Friedrichsruh to deliver my message and bring the Sultan's present. In reply I received a letter regretting that, owing to his bad state of health, Prince Bismarck was not allowed to see any visitors. Count Rantzau suggested that I should forward the present by rail, and deliver the Sultan's message in a letter direct to the Prince. I consequently sent the case to Friedrichsruh, and wrote Prince Bismarck a letter, in which I notified the despatch of the vases and gave a summary of my message from the Sultan.

The last communication I received from Prince Bismarck was a letter written to me by Count Rantzau at his wish. I had contributed a paper to the April (1898) number of Harper's Magazine dealing with the relations between England and Germany. Therein I endeavoured to show that, whereas fifty years ago people had believed that the development of commerce and the improved means of communication between nations would bring them into peaceful if not friendly rivalry, the exact contrary has been the result. Rarely has the element of jealousy been so potent between nations as in our time. The English resent the growing commercial and political importance of Germany, and the Germans reciprocate such resentment with interest. Jealousy and recrimination are as barren 
for good in the life of a nation as in that of the individual. It is in the nature of things that nations should be continually misjudging each other, of which I impartially gave several striking instances. These occurrences, however, ought not to blind us to the fact that it is in the best interest of both England and Germany that the bitter feeling of the present should give way to a more conciliatory spirit on both sides; all the more since United Germany is no longer the Cinderella among nations which she was in the past.

I sent a copy to Prince Bismarck, who, through Count Rantzau, sent me the following acknowledgment :-

\section{Translation.}

"FRIEDRICHSRUH,

$$
\text { "April, 1898. }
$$

"Dear Mr. Whitman,-My father-in-law has read your article with great interest, and desires to thank you for the impartiality which you have treated the subject (England and Germany). He says you are well aware how highly he values many Englishmen and Englishwomen, although he is sorry he is unable to say the same of English politics. He too regrets that the relations between Germany and England are not better than they unhappily are. Unfortunately he does not know of any adequate remedy for this state of things, since the only one he is acquainted with-that we Germans should restrict our commercial industry-is not well applicable.

"With hearty greeting, dear Mr. Whitman,

"Believe me,

"Yours very truly,

"G. Rantzau." 


\section{CHAPTER XV \\ BISMARCK'S DEATH}

JULY 3OTH, I 898

$A^{\text {BOUT a fortnight before Prince Bismarck's }}$ A death disquieting rumours concerning his health began to appear in the London papers, to be in turn contradicted and reiterated. As this had repeatedly happened of late years, it did not at first cause any particular anxiety among his friends. Only a few weeks previously I had been at Schoenhausen and had been assured by Count Herbert Bismarck that, although his father's neuralgic pains were more troublesome than ever, yet, according to Doctor Schweninger, there was nothing organically amiss with him. For all that, every recurring alarm could but cause additional concern, if only in view of the Prince's great age. However, a few days later the reports became distinctly more reassuring, and a fatal result seemed once more, as so often before, to have been warded off by the Prince's skilful physician.

I started for Friedrichsruh early on the 3oth of July with the intention of staying in the village 256 
until Prince Bismarck should be decidedly better. Loth as I should have been to undertake the journey with the prospect of finding the Prince at death's door, I was glad to do so in the hope of seeing him once more on the road to recovery. As it unhappily turned out, Prince Bismarck passed away whilst I was travelling towards Friedrichsruh. The sea was exceptionally rough for the time of year. A fierce gale raged that very night all along the North Sea coast, and there was quite a raw autumnal chill in the air in the morning. The elements-as at the death of Napoleon the First, when trees were uprooted in the island of St. Helena - seemed to participate in the tragic occurrence.

I arrived at Hamburg early on the morning of the 3 Ist of July, intending to proceed later in the day to Friedrichsruh. However, I had not been half an hour in the hotel when, on coming downstairs, I saw an old woman-harbinger of ill-luck in German hunting lore-standing at the door of the hotel offering a black-bordered newspaper for sale. "Prince Bismarck died last night at eleven o'clock" was the laconic announcement in big type.

I left Hamburg by the next train for Friedrichsruh. The shops were closed, for it was Sunday; but all flags on public and private buildings, as well as those to be seen flying from ships, were at half-mast. It was the same all along the road to Friedrichsruh.

There was hardly anyone about, either at the Friedrichsruh station or in the village; only a small 
group of people stood in the road silently peering through the gate of the Prince's residence. To anybody arriving at Friedrichsruh under the impression of such a stirring event-one which, at that very moment, was thrilling the telegraph wires from one end of the world to the other-there could but be a sense of disproportion between the stir in the distance and the quietude on the spot. Nobody seemed to have heard or know of anything. At the inn, however, there were already some signs of the unusual. Every bed except the one I was fortunate enough to secure had been engaged by telegraph. Fifteen extra officials had arrived at the post office; four extra telegraph apparatus were already at work, and I was told that sixty soldiers and three officers of the 3 Ist Regiment from Altona-as well as a detachment of Halberstadt Cuirassiers-were expected.

In the afternoon I met Professor Schweninger coming out of the Schloss. He was bareheaded, and evidently in a state of nervous depression. He told me that Prince Bismarck had passed away peacefully the previous evening in the presence of his family. The immediate cause of death was congestion of the lungs. His last words were "Ich danke Dir, Mein Kind," addressed to his daughter, who had wiped the moisture from her father's forehead. Immediately after his death the windows of the bedroom, which were on the ground floor, were thrown open, and the household gathered in the garden could see their master lying at rest. 
Schweninger told me that so little did Bismarck realise the end was near, that as late as the day before his death he gave one of his servants two large meerschaum pipes to colour for him, as he had done on previous occasions.

Prince Bismarck had suffered latterly from frequent intermittent soporific attacks, during which he sometimes dropped off into a sound sleep, and at other times suddenly recovered full consciousness. Yesterday afternoon these attacks increased in frequency, and towards the evening took a more serious form until death ensued. But even as late as yesterday morning the Prince read the Hamburger Nachrichten as usual, and spoke to those around him about politics. His last remarks upon political matters referred to Germany's relations with Russia, at all times a subject of deep concern to him. Schweninger further assured me that Prince Bismarck's death was felt all the more acutely by the family, since they had come to believe in him as a magician, and that the Prince would never die as long as he was near. "Years ago I certainly did say that I hoped to bring him to see the age of ninety, but even then I had to reckon with the baneful effects on his health of the worry and excitement connected with his dismissal in I890. Recently, however, I have been prepared for the worst, and have lived continuously on the move backwards and forwards between Friedrichsruh and elsewhere. Last Thursday I managed to rouse him to come in to dinner. I said 
to him, 'We must drink a glass of champagne together.' We did, and he was in such good spirits, that incredible as it may seem, he smoked as many as five pipes in succession. I then persuaded him to go to bed before I left for Berlin, which I was obliged to do; although, even then, I feared it might be a case of days only with him.

"Yesterday morning the family telegraphed me to come back at once by special train, but that could not have brought me sooner than I came. His last moments were singularly free from pain. His end was as the final flicker of a flame. This afternoon I shall embalm his body myself-the last service I can render him. He will probably remain for the present in the room in which he died, for he is ultimately to rest in a mausoleum which is to be built on the hill opposite the Schloss, on a spot the Prince once selected himself. We were out walking together two years ago, when he said, 'I should like to be buried here, just opposite where I have lived the last years of my life.' I told him that in that case it would be best to put it down in writing. He did so, and this morning the document was read aloud in the presence of his family. By his express desire his tomb is to be inscribed with the words :-

' HeRE LIES

PRINCE BISMARCK, A Faithful German Servant OF THE

EMPEROR William THE First.'” 
There was a subdued tone in the conversation that evening among the guests in the inn.

Early next morning (Monday) I was awaked by hearing my name called out repeatedly in a loud voice. I opened the window, and looking out saw Schweninger standing below. He asked me to make haste and join him, which I lost no time in doing. He bade me follow him, and silently led the way towards the Schloss.

It was between four and five o'clock, and not a soul was about. Everybody was still asleep. Only the birds he loved so well were stirring overhead, chirping merrily in the thickly leaved trees. They could not know that the man who knew no fear, and therefore, according to the German Saga, was privileged to understand their language, was lying dead close by and would hearken no more to their lays.

Two Cuirassiers in their white uniform stood with drawn swords as sentinels at the door of the house. We glided on tiptoe through the wellknown apartments on the ground floor and entered the bedchamber, in which but a few hours before Prince Bismarck had breathed his last. Two of the Prince's foresters, clad in a grey-green uniform, stood on guard by the bedside.

Prince Bismarck lay in death in the position habitual to him when asleep, as Schweninger assured me. His head was turned towards the left, and slightly bent down on the chest. $\mathrm{His}$ arms were stretched out nearly at full length over the bedclothes. 
In his left hand was a white rose, placed there by Professor Schweninger, and three dark roses sent by an Austrian lady. His features, rigid in death, still retained their proud repose. Bismarck's whole life had been one continuous battle, and the zest of it-gaudium certaminis-had been his throughout. So even in passing into the Valley of Silence there was a struggle. To look at his ashy pale face was to feel that a fire had burnt itself out. You could not help saying to yourself, "There must have been a grim battle here before this mighty embodiment of human will had been wrestled with and thrown."

I glanced around the plainly furnished room. On the wall over the head of the bed hung pictures of a favourite horse and dog. To the left portraits of Princess Bismarck, their son William, and one of Schweninger by Lenbach. Near the window stood the little shaving table which Bismarck had used only a few days before. At the foot of the bed I noticed the Prince's weighing machine, and a little further away the sofa on which Schweninger had slept for some months past during his visits.

The next room, which had been the Prince's private sitting-room, was filled with all sorts of odds and ends, possessing some interesting connection with him who was gone. I noticed a large oilpainting - a portrait of the Princess encircled with a garland of evergreens-the invalid chair in which, latterly, he used to be wheeled in to dinner, a suit of çlothes neatly folded on a chair with a white shirt 
uppermost ready to be put on in the morning, which, alas! never came for him. Books, papers, letters and telegrams were strewn about. A faded laurel wreath lay side by side with an open leather case containing the insignia of a new Siamese decoration for him who had recked little of such things. Among other items I noticed four pairs of peculiar South American stirrups with leather shafts to protect the leg, lately received as a present, and a birthday gift from the Emperor, a beautiful crookstick of the form which Frederick the Great fancied, the crook of solid gold.

A picture of $\mathrm{Li}$ Hung Chang rested on the floor, a model globe of the earth, Bismarck's chess-board, his battlefield, with raised mountains and channelled seas, was on the table.

In the hall hung the familiar array of hats and cloaks. The well-known walking-sticks were there too, and for the moment they almost seemed to be animate things. Sadly I passed the soldiers at the door, out into the open air of the morning, and strolled far away into the forest along the roads and the bypaths he had loved so well. Suddenly I saw a dark van drawn by two horses standing before me. A flap was wide open and inside a huge coffin was visible. It had come by road from Hamburg during the night, so as to arrive before people were astir in the morning.

I bent my steps back to the inn, where I found a telegram from Lenbach, saying he would arrive in a few hours. I met him at the railway station and 
accompanied him to the gate of the Schloss, where I waited whilst he went in to take a last farewell of one who had been an affectionate friend as well as an idol to him. He was not long gone, and when he came out he said-

" Bismarck looks noble and dignified, very much in death as in life, though of course much paler. His hands, always beautiful, have become still more refined. Death has not changed him as it did Döllinger, who in life had a somewhat reddish face which in death was idealised almost to marble, giving it the appearance of a cameo." As in the case of Goethe, Bismarck "rested as one asleep. Peace and firmness reigned o'er the features of his lofty, noble countenance. The mighty brow still seemed to harbour thought." Here too were indomitable strength and symmetry; two fundamental conditions of comeliness in man. Bismarck's virile beauty was an article of faith with Lenbach. More rugged than Goethe, but still classically symmetrical. In the same way as the battle of war and diplomacy is rougher than that of the struggle for spiritual life, is the picture more rugged; but that is the sum of the difference in death between the two great men who had fathered intellectual and political Germany.

We strolled about the village as we had often done before on happier occasions. Lenbach told me that when he was here three years ago, on Bismarck's eightieth birthday, on parting he told the Prince 
that he felt sure he had many happy years yet before him.

"My dear Lenbach," Bismarck replied, "the first eighty years of a man's life are always the happiest."

More recently still, the last year, after another visit, in saying good-bye Lenbach again expressed a hope that his friend might live to see many happy days. To this Bismarck replied, "There is only one happy day left for me. It is the one on which I shall not wake up again."

A small crowd kept gathering and dissolving all day long in front of the Schloss during the Monday and Tuesday following Prince Bismarck's death. It included a number of persons of distinction from far and near. Some had been personally acquainted with Prince Bismarck, but they preferred to stand in the road with the rest rather than to trespass on the family with expressions of "sympathy.

Some interesting reminiscences were exchanged by those who knew the great statesman personally. It was a matter for general comment that the offer of a State funeral had been declined, also that no post-mortem examination nor even the taking of a cast of the Prince's features had been permitted by his son.

I had intended to leave Friedrichsruh as I had come, without intruding beyond the inscription of my name in the Visitors' Book at the lodge. But Prince Herbert sent me word in the course of the 
morning (Tuesday) that he would like to see me. I followed the servant into the Schloss, where I found the whole family in mourning, assembled in the apartments on the ground floor inhabited by the late Prince. They received me in silence, but shook hands with the cordiality of friends. I was about to retire when Prince Herbert asked me to come into the room in which his father had died. The bed had been removed, and in its place stood a darkpolished oak coffin, the one I had met in the forest. It was of unusually large dimensions, with eight massive silver-plated handles and four pedestals of the same metal in the shape of lion's paws. It rested on trestles and occupied exactly the same spot on which the bed had stood; the head of the coffin, as his son pointed out to me, was within touch of the bell-rope which Prince Bismarck used when summoning his attendants. The walls of the apartment were draped with black cloth with a thin silver border; a pair of huge silver candelabra, each with twelve lights, were the only ornaments in the room. The whole floor was covered with wreaths and green palms, the usual German emblems of mourning. Long white sashes were attached to each of them, on which the names of the senders-corporations and eminent persons-were printed in gold letters. The coffin was covered with a black veil, through which were plainly visible the handles and pedestal. On the coffin itself rested garlands of roses, tributes of the Prince's children and grandchildren.

A couple of rows of cane-bottomed chairs and a 
very primitive prayer-desk stood in readiness for the funeral service, which was to be held in the afternoon as soon as the German Emperor should arrive. The preliminary service, the consecration of the body and the partaking of the Holy Communion by the family, had already taken place. Prince Herbert seemed to feel a melancholy satisfaction in drawing my attention to these details. It afforded him some consolation to think that his father had been free from physical suffering at the last. For he told me that he had passed gently from insensibility to death - " to God, who has taken him into His keeping," he added in a husky voice.

The Emperor arrived in the course of the afternoon, and the funeral service was celebrated in his presence. Several journalists obtained admittance ; I did not attempt to do so. In coming out of the Schloss I met Professor Schweninger, and we strolled up the hill together on which the mausoleum was to be built, and sat down on the rude wooden bench where Prince Bismarck used to rest and gaze over the valley leaning on his stick, wrapped in thought, and where, sitting with Schweninger, the idea first struck him that he would like to be buried on that particular spót.

"You must know that Bismarck had a peculiar horror of what he called a first-class funeral-' Ein Leichenbegaengniss Erster Güte,' as the Berliners describe it. He was even apt to dub the ceremonies attending his departure from Berlin as a 'first-class funeral.' Hence his determination 
during his lifetime to fix where he would like to rest was doubtlessly dictated by his strong aversion to a formal public funeral. Yes, here he will have a cathedral all to himself, arched over by the oaks and beeches he loved so well. And although I must needs leave him here in solitude, I shall always make a pilgrimage to his resting-place on April Ist, his birthday, a sacred date to me. For my own satisfaction I want to prove that there is such a thing still extant as 'Deutsche Treue,' the vaunted German fidelity of old."

Schweninger said that Bismarck's death had left him forlorn, without any further ambition.

"For nobody will ever be like him either in personal distinction, in refinement of feeling, or in the truly regal proportions which were his. You knew him too, so you will understand me when I say that in his composition there was something of the tenderness of the woman, much of the naïveté of the child, and all the qualities of the man."

Bismarck's humour had occasionally shone in all its brightness until the last; but his spirits had visibly declined during the final few months.

"I would like to live," he once said, "but not with those neuralgic pains. I prefer death."

The isolation in which he lived sensibly depressed him. There was nothing morbid about him, he never cared for solitude, and he was unutterably lonely. "I am glad you have come," he would say to Schweninger. "I turn to others, but they do not understand me; what I say to them is like water 
running down the back of a pelican," he would declare sadly.

At times when something in the conduct of public affairs did not go exactly to his liking, he would burst out pathetically, "Ah, I should like to give them a bit of my mind": "Ich kann aber das Stüeck nicht mehr blassen" ("Alas! I am no longer able to play that tune ").

A pathetic feature connected with the last few months of Prince Bismarck's life was that all his favourite dogs, his constant companions, had died before him. Not one was left to whine its grief beside his bier.

I left Friedrichsruh for Hamburg, where I stayed until the end of the week. Many of the shop windows showed busts of Prince Bismarck in front of a background of flowers and evergreens. On Saturday morning the church bells tolled in celebration of a public funeral service to his memory. 


\section{CHAPTER XVI}

\section{FRIEDRICHSRUH}

$$
\text { JULY, I } 899
$$

$\triangle$ NOTHER year has passed, all but a few brief A days. It is the 27 th of July, 1899 , and once again I am at Friedrichsruh, whither the words of a mighty exile had so long drawn the attention of the world. The mausoleum is completed, and therein, side by side with those of his devoted wife, the remains of Prince Bismarck have been piously laid in their last resting-place, united in death as in life.

A grey-uniformed Jaeger had been sent to meet me. From him I learn that Prince and Princess Herbert Bismarck are in the mausoleum, and that he, the Jaegersmann, is to escort me there.

We cross the railway line and ascend the rising ground. In front of us is the newly built porter's lodge-clean, whitewashed, and tidy-looking, inside and out, but its walls are still damp. Gently the Jaeger lifts the latch of the gate as we pass into the inclosure. The plain Romanesque structure which harbours all that was mortal of the 
Unifier of Germany stands against a background of trees. To the right, under the shade of spreading oaks, I noticed the wooden bench on which Bismarck loved to sit, where I had sat with him myself, and from which he had pointed out to Dr. Schweninger the exact spot where he wished to be buried. We enter the building just in time to listen to a hymn Princess Bismarck is playing upon the organ. Prince Herbert stands bareheaded in the aisle, as if in prayer, and near him is his secretary and several of his retainers. There is something devout in the evident fervour of those present, and there is something chaste in the simplicity of the chapel itself.

"My father loved simplicity," said Prince Herbert, as he showed me round afterwards.

The light streams in through the painted-glass windows and falls on the plain yellow marble sarcophagi within which lie Prince Bismarck and his consort. Wreaths of flowers, of evergreen, of wrought iron, and even of silver are strewn upon the stone slab, from whence those of an imperishable nature will be gathered up and stored in a museum set aside for the purpose.

A small altar stands to the right of the porch. It bears an inscription from Colossians iii. 23: "And whatsoever ye do, do it heartily, as to the Lord, and not unto men."

It was the text chosen by Schleiermacher for his sermon when Bismarck was confirmed. His son is willing that strangers should come to see his 
father's grave, but he cannot endure the thought that such a visit should be made the excuse for picnic-parties, for nobodies littering the ground with their tributes, or scribbling their names on the walls which are sacred to him. The same instinct which made him dislike the idea of a public funeral and all the hollow pomp inseparable from such bids him object to such desecration. But he is willing to accept that which bears the impress of sincerity and reverence.

"My father died as a private citizen," he says, "and in death I do not want him to be made the attraction of the holiday jousts of the 'general.' Therefore he has made arrangements that those who wish to visit the mausoleum shall first apply to the lodge-keeper, and only be admitted in limited numbers, as befits the small dimensions of the building.

We take leave of the mausoleum and wend our way past the porter's lodge, across the railway lines, through the strong iron portals into the Schloss. It is familiar ground; but the figure has gone that lent Friedrichsruh its charm, its worldwide celebrity. Not a chair, nor a table, nor a picture has been moved from its place-eloquent testimony to the veneration which dwells in the hearts of those who inhabit these rooms. The large writing-table in the study is there, the sofa, also the mahogany card-table on which the preliminaries of peace were signed at Versailles. A drawing hangs on the wall; it is that of the garden 
house in which Bismarck lodged in Göttingen as a student.

In the middle of the bedroom stands the wooden bed still in the same position it occupied on the day he died. The head hard against the wall, the bellrope close handy on the right-hand side. The bed is covered with a reddish-brown silk quilt, upon which lies a bouquet of flowers. Everything else is as he left it; the pictures on the walls, even the brushes and combs and toilet and medicine bottles are untouched.

In the other rooms on the ground floor I noticed a few nicknacks I had not seen before, otherwise all is as it was of old even here. Not a stick has been removed. Lenbach's portraits of Bismarck and the old Emperor William still look down from the walls; some ancestors of the Bismarck family are in their old places all untouched.

I left Friedrichsruh the same afternoon. Prince Herbert walked with me to the station.

The Prince converses in his earnest, forcible manner, as if bent on bringing conviction to the listener by the emphasis of his diction. His kindly words breathe the interest of a friend. The tone of his voice, even the substance of his words, intimate that, although the circumstances which brought us together in life have passed away, the sentiments they engendered have not changed. But even a sense of gratitude on one side and a feeling of friendly regard on the other are not always sufficient to keep those in touch whom 
different interests and spheres of life have placed asunder. It was as if a chapter in my life had come to a close. A full term of seven years, during which the figure of Prince Bismarck had so often been uppermost in my thoughts, and my personal relation with him and his family a constant source of gratification and pride to me. Something tells me that it is all done with now.

Bismarck's spirit hovers over all Germany. On the evening of his birthday you can see it aflame on the crest of a hundred hills. There is one place above all others where you feel that he is no longer among the living. It is there where he diffused life and sunshine-at Friedrichsruh. His countrymen will seek him again in the busy life of the country which he fashioned; in the books that tell of his deeds and his daring; but not 'neath the trees, under the shadow of which he loved to roam. Anywhere but there. The wanderer shuns the glade which the gods have deserted.

And I looked up at the stalwart figure before me, heir to his father's name. A certain aggressive tenacity is evident in his features-in the close-knit forehead, the bushy eyebrows, but, above all, in the steady, piercing expression of the eyes. These reflect that peculiar kind of fearlessness which is associated with the term "leonine"; that which measures not the size of an antagonist, nor stops to ask how goes the fight. And there is an expression of kindliness with it all; a something that 
denotes generosity and the capacity for steadfast affection. Here it was that I saw the likeness to his father.

I recalled to mind those who, from time to time, had naively asked me whether Herbert Bismarck shared the greatness of his father. And I thought of the disgust which I knew by adequate experience such a connection of ideas would excite in the breast of one to whom personal vanity and petty self-seeking are contemptible traits.

And I remembered an incident of years gone by, how a friend had thoughtlessly asked him where he expected to take up his residence in the event of his father's death.

"My father's death?" he replied in almost angry agitation, "I have never thought of that." His words came from the heart, and he kindly forgave the thoughtless questioner.

I looked at him still, as all this flashed across my mind. I may have even thought that I detected some furrows, some roughnesses in the picture, such as Cromwell insisted should not be left out of his portrait, signs of nervous restlessness: the penalty of being born and bred in an age of railways, special trains, and telegrams : for these have, indeed, robbed us of the repose of our fathers. Such as he might speak in haste or in anger, and, perhaps, ride roughshod over the sensibilities of a whole community. But he could never stoop to insincerity: a whole-hearted man, who scorns the trickery of cunning. 


\title{
CHAPTER XVII
}

\author{
EPILEGOMENA
}

"A golden mind stoops not to show of dross."-SHAKESPEARE.

$W_{\text {ance he had just completed his seventy- }}^{\text {HEN I made Prince Bismarck's acquaint- }}$ sixth year; a term of life at which most men already show signs of failing mental power. Nobody would recognise the stern Duke of Alva of ruthless memory in the portrait of the goodnatured-looking old gentleman to be seen in one of the picture galleries of Madrid. According to Oliver Wendell Holmes :-

"Some of the softening effects of advancing age have struck me very much ... in the gradual passage from maturity to helplessness the harshest characters sometimes have a period in which they are gentle and placid as young children. ... I remember a person of singularly stern and lofty bearing who became remarkably gracious and easy in all his ways in the later period of his life."*

O. W. Holmes is careful to say that sometimes such changes are wrought by age. With Bismarck

* The Autocrat of the Breakfast Table, p. 115. 
this was not the case, although shortly before I went to Friedrichsruh for the first time I was confidentially informed that the Prince was no longer his former self. I was told that his memory was defective, his conversation had become that of old age, and even his massive head had shrunk in size. It was whilst strolling along the Wilhelm Strasse, in Berlin, that I was thus enlightened.

That which I had heard the Prince's detractors assert concerning the decline of his faculties often came back to me with a sense of surprise and wonder in the course of my various visits to Friedrichsruh. Now that he is gone to his rest I can truthfully say that never down to and including the last time (June, I896) that I was in his company, would it have been possible to perceive the slightest indication either in his appearance or in his manner of such a falling off commonly associated with old age. His aphoristic crispness of speech was as spontaneous and concise as ever. There was never a word too much or a word too little in what he said. Everything was lucid and to the point. This was all the more striking to the listener, since others spoke hesitatingly, disjointedly in his presence. The aptness of his repartee, the deftness and rapidity with which he would seize upon any point which might interest him in a conversation going on around him, often called forth the admiration of those present. 
Even those who had no opportunity of observing Prince Bismarck in his home might form for themselves a fair estimate of his undiminished fund of truculent combativeness, united to perfect mental equilibrium in his old age, by recalling the polemical incidents of that exciting period, commonly known as the "Bismarck Hetze of I89I-2." Now that ten years have elapsed it is easier to weigh dispassionately the pros and cons of that controversy; and whichever side one may be inclined to take, it is impossible not to be struck by the deliberate character of every move Prince Bismarck madethe self-control he maintained throughout a duel in which his opponents were the whole machinery of official Germany. Amid the turmoil of mutual recrimination, including the gloating comments of the foreign Press-the shrieks of his detractors accusing him of having undone the work and reputation of a lifetime-Bismarck showed himself to be the wary intellectual gladiator of old and throughout master of the situation. This must be clear to anyone who cares to read up the subject. His opponents came out second best from the encounter. Who heeds their denunciation to-day?

But even more remarkable testimonies of almost superhuman strength of mind in old age are brought home to us by a glance at the numerous speeches Bismarck made during the last years of his life to the different deputations which visited him from time to time at Friedrichsruh. An enormous intellectual versatility, as well as physical 
powers of resistance, were evident through the endless receptions which followed each other. Every word he spoke was noted down and subjected to the critical eye of the enemy; relentless commentary dealt with every thought, every sentence. And yet not a single lapsus, repetition, or commonplace do we discover in all these manifestations of a mind the resources of which seemed to be inexhaustible. Not even plebeian malice has been able to make mud stick here.

Bismarck's was one of those natures that knew not the softening, much less the humiliating, effects of decay. And thus he remained, as Professor Schweninger assured me on the morrow of his death, to the very last. It was a gracious dispensation of Providence that so many of Germany's heroes - among others Goethe, the Emperor William, Moltke, and Blumenthal-whilst attaining to the age of patriarchs, should have been spared a lingering illness. Bismarck, like each one of these eminent men, was taken in the possession of all his faculties-a fate he envied in others, and would have wished to be his own. People sometimes styled him einen Greis - an untranslatable term for old age, which implies senility-and they meant it kindly. As a matter of fact, Prince Bismarck died unassailed by senility. His hair was snowy white, as is that of many men at seventy, but that was all. The proud carriage of his head was intrepid and defiant to the last, as 
of one who all his life had had enemies and the habit of overcoming them. The fire of geniusthe glitter denoting indomitable will power and vitality combined-gleamed undimmed from those eyes up to the moment when they closed for ever.

\section{II}

In April, 1891, Prince Bismarck had been out of office exactly thirteen months, and had apparently become reconciled to his retirement. To the superficial observer his frame of mind, like his outward appearance, was that of a country gentleman of distinction, of military bearing, who once upon a time had been actively engaged in politics - a period he now looked back upon as a nightmare peopled by memories of treachery, duplicity, and ingratitude. Only gradually, in consequence of remarks dropped here and there, either by Bismarck himself or others near to him, was a visitor able to form some idea of what had gone before and what was still raging in that most sensitive heart.

In the course of his long career Prince Bismarck had often threatened to resign office and retire into private life, for which he always declared he yearned. It was not necessary to know him personally in order to be convinced that he was sincere in this longing to be rid of the worries and annoyances of political life; for sincerity was to 
him as the very breath of his nostrils. The event, however, when it came about, proved that he did not know himself in fancying he would ever willingly take to the leisure of retirement in exchange for the worries of work.

Germany had been to him even more than a wife could possibly be to such a man. There was a touch of romance in his attachment to his country. It was a schoolboy's vivid dream, begun long before the age when a "young man's fancy lightly turns to thoughts of love." The master passion of a life imbibed in the cradle for some exacting fairy such as we read of in German folklore. A compact between a Child of the Earth (ein Erdenkind) and an Immortal-for a nation is immortal-who, in return for certain favours of fortune, insists on life-long devotion. There were times when he grew sick of her exactions and, above all, of her ingratitude. He threatened to leave her, as many an irritable man has threatened to desert the woman he loves. But when the supreme moment came, he discovered, like others before him in humbler circumstances, that a thousand minute fibres, reaching down into the inmost recesses of the heart, bind us to the object of the devotion of a lifetime. Suddenly this most intimate of relationships must cease. $\mathrm{He}$ is not even told who is to take his place in caring for Germany; much less is he to know of the life she is to lead in the keeping of another. For thirty years he had been listening, as it were, at a microphone-a thousand 
wires had given him timely warning of the faintest breath that could injuriously affect his country, so that he might guard against it. Henceforth the welfare of Germany was to be no concern of his. He was to know nothing, to be consulted about nothing. All this Bismarck only realised when the event had taken place, and it was agony. He considered that he had been treated with the lack of that courtesy which he held ought to be meted out even to the criminal on the scaffold. He was not consulted-not even told-who was to be his successor. He first saw the name in the newspapers, and learnt subsequently that Herr von Caprivi had been taken into the Emperor's confidence as far back as the Ist of February, with strict injunctions not to mention a word to Bismarck! Incredible as it may seem, all but Prince Bismarck's relatives and a few intimate personal friends broke off social connection with him and his family. Hitherto a hundred newspapers had been eager to report his slightest word; now not one was left to support him in the capital of the empire he had created. His son, Count Herbert, found Berlin a strange city.

When I came to Friedrichsruh the fire of Bismarck's anger had died down, it was smouldering beneath the ashes. His heart was still steeped in bitterness--he had no idea of the place he still held in the affections of his countrymen. His judgment was for once at fault. Only after his son's marriage, as he approached his eightieth year, 
did he gradually regain that faith in his countrymen which had been so rudely shaken. There must have been a proud consciousness that the extraordinary popularity which shed its rays over the last years of his life was a tribute paid to him on his own terms. He had scorned to keep back or recant a word that might have imperilled it. He would accept nothing at the price of a lie. His popularity came as the reward of a conqueror among men who dictates his own terms and accepts homage as his due. Unique as a triumph of character was this tribute rendered by a whole nation to an old man in private life.

\section{III}

Painting, photography, and every other form of artistic reproduction have made the world familiar with the personal appearance of Prince Bismarck. Among their products his many portraits by Professor Lenbach are easily first, those in civilian dress being, I think, the finest.

A military coat enhances the appearance of most men, even of some of the greatest. We cannot imagine Napoleon in plain clothes. The ruthless determination of a Moltke was fittingly set off by the comely Prussian so-called "undress" uniform and the cold blue cross of the Order "Pour le Mérite" hanging from his neck. With Moltke 
the cross did not look like a bauble, it was the hallmark of his military genius. No uniform or ornaments, however, could have added to the distinction of Bismarck. In a certain sense a military coat interfered with the intellectuality of his countenance, the aristocratic distinction of his whole bearing. Dressed in the conventional black frock-coat, scrupulously neat and tidy as he always was, Bismarck stood above every decorative effect.

One of the best photographs of the Prince is a profile taken by Loescher and Petsch,* of Berlin, in his seventieth year, although, as a profile, it does not, of course, give either the breadth of the full face nor the expression of the eyes. But in no other portrait do the strength and symmetry of Bismarck's countenance stand forth so clearly, nor in any other is the curve from forehead to crown and across the dome of the skull-the beautiful line of ideality-ending with the bold sweep down to the back of the neck, so distinct. The measurements from the brow to the ears, and from these to the crown of the skull, are very remarkable. The shaggy beetling brow shelters the glance of his piercing eyes. His large but well-shaped ears lay back against the skull in an almost perpendicular line which gave a certain truculence to them. They were perfectly poised. Nose and chin were almost parallel in outline, their contour being only broken by the curve of the moustache. It is a fine face, and it would * See frontispiece. 
be impossible to suggest the slightest alteration without a distinct loss of something characteristic.

Ears and eyes were the most strongly marked of Bismarck's features. It was fit that the organs of perception should have been abnormally developed in the Sentinel, whose special functions were those of "seeing" and "hearing." Bismarck's ears had something of what the Germans in their sporting phraseology call "Lauscher" ("Listeners"), the ears of the deer of the forest. Formerly the German Michel* had been sadly deficient in the sense of hearing. He was often deaf to what was going on in the world until foreign horsemen let their steeds graze loose on German fields. Here was a man whose hearing was so acute that, as I have had already occasion to quote the old saying, "he could hear the grass grow."

The organs of perception fitted harmoniously with those denoting power of action. The chin had naught of the implacable, as with Napoleon. Its roundness revealed the man who knew how to conciliate by his moderation. The bold sweep at the back of the head showed the constructive ability of the architect which enabled Bismarck to weld together, to rebuild where he had been obliged to destroy. ... .

When engaged in conversation, the firm lines of the mouth were visible beneath his moustache; as also a set of small, regular teeth which he retained almost intact to the last. Bismarck's hands might * The national figure-the John Bull of Germany. 
have been those of a man of fifty, so little did they bear the marks of age. Even in death they were still unmistakable indications of strength and refinement.

Bismarck had an unusually small foot. One day -it was at Kissingen in I 892 , when I was walking with him-he complained of something having got into his boot. He sat down on the bench and took off one of the high-top boots which he always wore, and I was surprised at the extreme smallness of his foot, as well as at the fact that over seventy years of boot-wearing had apparently not produced the slightest detriment to its original shape. Only among Circassians have I ever seen such small feet with so tall a stature.

When Bismarck was not in uniform-or at Varzin, where he sometimes wore a grey-green shooting jacket and a cap of the same material with lappets and ribbon to let down and tie over the ears in cold weather-he always wore the conventional double-breasted, black frock-coat together with a black waistcoat, black trousers, and a white or cream-coloured scarf or cravat, apparently going twice round the neck. A dress much like that worn by German Protestant clergymen. Newfangled ideas of attire and adornment were never to his liking. Extreme simplicity of dress, as of speech, was second nature with him. He always looked extremely neat. His clean-shaved face (shaving was a function he performed himself down to his last days), in addition to his fresh, 
rosy complexion, gave him a peculiarly tidy and healthy look. Now and then he put me in mind of a freshly painted. Dutch country-house, the speckless aspect of which is a good indication of the morality of its inhabitants; the morality inseparable from order and cleanliness. Next to his skin he wore an unstarched, white linen shirt; no flannel or undervest of any kind. Schweninger did not approve of flannel underclothing. In January, I 892, on a bitterly cold day, I accompanied Prince Bismarck in a sleigh drive near Friedrichsruh. I noticed that where his fur was open in front he had nothing but a plain white linen shirt between the bare skin and a biting easterly wind. Nevertheless he told me that I was too thinly clad, and, before starting, insisted on my putting on one of his stout overcoats over my own.

Biographers have been prone to dwell on Bismarck's physical strength, and he has been caricatured as the "strong man" of the circus. Yet nothing could be more unlike him than what the Germans ironically term the "strong man," showing their contempt for the mere trained animal, the professional athlete. So far as power of sinew, enormous vitality-abnormal capacity for work and powers of digestion-go, Bismarck was undoubtedly a very strong man. But the idea of the symmetry of his figure always predominated, in the same way as the balance of his mind always seemed more striking than even its force. As Schweninger said one day: "Strength is a relative term; 
balance-the harmony of every organ-is the principal thing and the real test of health. We are only as strong as the weakest of our vital organs." Bismarck possessed this rare combination of allround health and strength.

A stranger walking Unter den Linden in Berlin might meet someone now and then reminding him of Bismarck by the type of countenance. $\mathrm{He}$ might meet tall, broad-shouldered, massive men by the score, but rarely one of Bismarck's stature, so well proportioned as he was.

Finally, Bismarck's voice was in accordance with his other characteristics. It is said to have been weak. A voice which in a man of eighty was still audible five hundred yards away in the open air could not have been a weak one. As a matter of fact, Bismarck's voice was neither gutturally deep nor loud; but it was eminently sympathetic; the natural voice of a refined gentleman. The manner in which he used it in public was that of addressing his hearers as if they had been at the table with him-devoid of any attempt at effective intonation. A loud voice, however carefully trained, would not have been consonant with the refinement of the man, just as rhetorical efforts would have been out of character in him. They were not needed to move a gathering of Germans to tears. 
Those who form their estimate of Bismarck's manner by the impression conveyed in reading accounts of his dealings with his opponents would naturally suppose him to have had strong likes and dislikes with a very graphic way of showing the latter. I know not what impression he may have produced in his prime upon a political opponent-a truculent subordinate-much less upon an enemy of his country! It stands to reason that a man of such extraordinary energy added to extreme nervous irritability, engaged all his life in asserting his own will against others, must have had moments when the fortiter in re was not too harmoniously blended with the suaviter in modo. For all that, it is not easy to understand how stories could have obtained credence of the "roughness" of one whose most marked characteristics in private life were courtesy and refinement. Or is it perhaps that what one generation dubs "roughness," another may hold to have been sincerity? In every case testimony is overwhelming to-day of Prince Bismarck's charm of manner; the fascination he exercised over those with whom he came in contact-not merely during his latter years, but at every period of his life.*

* In 1864 the present King of Roumania, then Prince Charles of Hohenzollern, wrote to his father: "Bismarck is positively irresistible in social intercourse." This opinion, although that of a young man, is none the less remarkable in view of the fact that both Prince Charles and his father were strong political opponents of Herr von Bismarck at the time, 
Towards the end dignity was emphasised by the repose of age, and the result was, as Lenbach so finely observed, that strength was blended with an indefinable "gentleness" (Milde). If Bismarck inspired fear, it was the fear that he might be chagrined and yet say nothing, not even express his feelings by a look. For he could put a whole volume into a look; not many have been so eloquent in their silence! I never heard him express a single opinion which could be construed as conveying an intense like or dislike.

Rural by taste, urban by instinct, few men have ever been so broad in the choice of those he admitted to his household. He liked what the Germans call "Naturmenschen" (the natural man), and declared that he discovered aristocratic qualities in him which are now and then lacking in the socalled "best-born." He was entirely free from that class prejudice which plays so formidable a part in German social life.

For the mere prefix "von" in itself Bismarck had little regard, and was amused at the eagerness of his untitled subordinates to obtain this distinction. He thought immeasurably more of those who did not ask for it nor value it-as for instance Lothar Bucher-than of many who possessed it. In Bismarck's eyes the prefix of German nobility was merely an indication that a man belonged by birth and training to a class which has imbibed similar ideas of decency, decorum, and general social amenities to those he himself had been 
brought up to, was accustomed to, and could not dispense with. When these were lacking in the "von" then there was soon an end to his claim upon Bismarck's social consideration. Whereas what he called the "nature's gentleman"-even though of obscure birth-always took high rank with him.

Only those who knew Bismarck well could understand the full meaning of one of his famous retorts upon his notorious parliamentary adversary, Eugen Richter, when he told the latter that his own education forbade him replying to certain offensive diatribes. Bismarck did not mean by "education" his knowledge of books, nor his qualification as a nobleman or as an officer, but his early training. He meant "the schooling of the nursery," the cultivation of "tact of the heart," in which he intended to convey that he deemed Richter, in spite of all his intellectual accomplishments, inferior to a Bavarian peasant or a Russian moujik. Bismarck was far more conscious and proud of this early training than of all the titlesthat of Prince included-which a sovereign could bestow upon him and on others less worthy than he.

Bismarck belonged by birth to the so-called smaller nobility; which, however, when allied to anciennete, enjoys a certain social consideration in Germany, if not de jure, at least de facto, above that of higher titles of more recent date. Thus it was not the mere title, but the record of his 
family - the fact that his ancestors had served the State for generations with distinction-to which Bismarck, like so many of his class, attached a certain value.

Other things being equal, I think Bismarck felt himself personally drawn towards the wealthier territorial aristocracy, such as the Bernstorffs, the Stolbergs, the Henckel Donnersmarcks, etc., as well as towards men of the same class in other countries, notably in Russia, Austria, and France. These, like himself, had-as their ancestors before them-always witnessed the drama of life from the stage-box. They therefore possess the ease of manner, the placidity of view which people almost only get by sitting all their life in the privileged seats of the theatre; whence they are able to look on at leisure and to lounge at will behind the scenes, without losing their equilibrium over the antics of the actors on the stage. Composure and self-restraint are a result of aristocratic association; they mark in every country the strong contrast of the few to the emotional exuberance of the many. And men who possess the same social characteristics naturally feel drawn towards each other. But even here the individual, the personality, was the real key to Bismarck's sympathies. Social status was, after all, only the passport to preliminary introduction, and not always that.

Political or agricultural topics and their exponents always interested Bismarck; military matters and military men as their exponents much less. 
It was possible to meet neighbours at his house for whom he had very kindly feelings, and whom he was pleased to see there, but with whom he might not exchange three sentences in the course of the year. The typical junker with his strong caste pride and class prejudices Bismarck had as little sympathy with as for the type which Napoleon at St. Helena termed "ânes par droit d'hérédité." Bismarck's intellect no less than his heart, his sense of "fairness" - a favourite English expression of his-revolted against indiscriminate malevolence levelled at a class. Thus when somebody expressed an opinion in his presence with the thought that it might possibly win his approval by contemptuously styling Lord Beaconsfield a Jew, Bismarck retorted, "Yes, but a refined Jew."

Doubtless Bismarck had his preferences and his antipathies, but they were rarely the outcome of prejudice. They were invariably the result of long observation and experience acting cumulatively on a sensitive nature. Thus, there were two classes towards whom Bismarck felt a strong antipathyclerics and bureaucrats. But here again there was no prejudice. His life-long experience of both these types had been eminently distasteful. Yet to the last he numbered personal friends both among clergymen and Privy Councillors.

The social station which he was fond of identifying himself with, and often referred to, was that of a country squire-a country gentleman. And in expressing himself thus he was well aware that 
the country gentleman in many countries, notably in Russia, Sweden, and England, does not necessarily belong to the titular nobility.

Prince Bismarck never deserved the ungenerous taunt enviously hurled at him by the German untitled middle classes-that he was a junker at heart.

Strange to say, neither Moltke's nor Bismarck's mother belonged to the aristocracy; they were both bürgerlich by birth. Thus if it be true that genius descends to us from the maternal side, the German people, as distinct from the exclusive German aristocracy, may well claim that the genius of these two extraordinary men was really a product of the German people.

\section{V}

Bismarck's customary attitude of nil admirari as applied to persons has led people to credit him with a contempt for mankind in general which was foreign to his nature. It is so easy to dub a great man a contemner, a despiser of his fellow-creatures. It looks effective in print. To begin with, Menschenverachtung is not a Germanic characteristic. No German is a hater of his fellow-men, except perhaps the professor who is afraid to ask his wife for the latch-key. A Roman, a Sylla indeed may have well felt a genuine contempt for his fellow-men. But even Napoleon broke down when he tried to 
apply the sentiment to his own family. Even his heart was not proof against sympathy for his own flesh and blood. But the man I had seen worried by the sick looks of a strange labourer could not, however much they might have tried him, have hated his species. It was impossible for him, the most sensitive of men, to entertain such a sentiment. Bismarck's habitual frame of mind might be one of indifference, as it doubtless was, but his heart was continually at war with his reasoning faculties; and when circumstances were sympathetic, his heart carried the day, for it contained a deep well of pity. It responded readily to an appeal of friendship, and above all to a sentiment of chivalry and devotion.

Sympathy and the need of its warmth was the keynote of his nature. Hatred and the exertion of hating, which politics brought in their train, in the same way as "tippling" is the adjunct of the wine traveller's calling, made him ill. Sympathy gave play to his humour and restored him to health.

Herr von Keudell, in his valuable Reminiscences, attributes to Prince Bismarck a deep interest in music. I do not believe that music appealed to him much. In other words, I do not believe that Prince Bismarck's mental moods were influenced by music. Incident, or a bit of nature, not melody appealed to him. His bent was dramatic, not lyric. He might write to his wife in a poetical strain ; but the descriptive dwarfed the sentimental. Music acted on him more as a reminiscence, as the sound of the post-horn might recall to us the 
memory of a certain journey. Erlebnisse - the memory of an incident he had lived through, not music, "put his feelings in motion." Student songs which recalled happy days of youth appealed to him far more than any symphony of Beethoven. Richard Wagner would have always been in the eyes of Bismarck an uncongenial eccentric.

No man could have had less taste for dogmatical discussions than Bismarck. Dogmatism was hateful to him. He loathed the arrogance of the proselyte, as well as every other form of arrogance and intolerance, as being vulgar and irreverent. His was essentially a religious nature. A deep sense of reverence, in face of the enigmas of the universe, was at the root of his religious feeling. On one occasion he expressed himself with regard to the theory of metempsychosis-one in which Count Moltke was also deeply interested. With Bismarck it may have been only a fleeting thought, but what he said on the subject was characteristic. "If I had to choose the form in which I would prefer to live again," he said, "I am not so sure that I should not like to be an ant. You see," he said, "that little insect lives under conditions of perfect political organisation. Every ant is obliged to work-to lead a useful life; everyone is industrious. There is perfect subordination, discipline, and order. They are happy, for they work."

Bismarck did not trouble himself about the spiritual welfare of other people. $\mathrm{He}$ was con- 
tent to let them take their chance in the realm of Frederick the Great, where everybody is supposed to obtain salvation in his own way. A certain dispassionate, philosophic calm was noticeable in him whenever the dead were mentioned in his presence. Even when they were those for whom he had entertained a feeling of attachment when alive. Conventional expressions of sympathy rarely escaped his lips. He would speak of the deadas his friend Motley, for instance, to whom he was sincerely attached-by recalling some quaint incident of their joint youth, but more in a jocular, sympathetic manner, entirely free from the sad thought that the old friend was long gone. Death in itself was only a natural incident. Thus to waste any conventional words about so natural a matter was repugnant to him. On the other hand, Bismarck's life was singularly free from the misfortune common to most men - that of prematurely losing those near and dear to him. He never lost a child, and his sister, Baroness von Arnim, survived him.

During the last months of his life Bismarck employed much of his time in reading. He always had a strong partiality for everything appertaining to the history of the first Napoleon, and read with avidity any books dealing with the great Corsican's career. He read General Marbot's Memoirs and Marshal Marmont's Reminiscences, both of which interested him deeply. Emile Zola's works also attracted him. He read the Debâcle, Rome, Lourdes, and Paris one after the other, but was somewhat 
disappointed with the last three. He expressed himself with regard to Rome that it reminded him of a traveller's guide-book. The Debâcle was more to his liking. But what particularly struck him was the fearless manner in which Zola told hard truths of his countrymen. Bismarck expressed himself to the effect that, after reading the Debâcle, he was not at all surprised that the French were making such a dead set at the author. For he had committed the unpardonable sin of telling them the truth. 


\section{CHAPTER XVIII}

\section{CONCLUSION}

"Goethe was silent. But I treasured his great and good words in my heart."-ECKERMANN.

T $\mathrm{T}$ has ever been reckoned a privilege to rub I shoulders with the great. Casual acquaintance with Goethe brought immortality to more than one mediocrity. But the glamour of mere worldly position diminishes in proportion as we approach it. The effect is much akin to that which Bismarck himself termed "seeing kings naked." The Germans have a saying: "Go not to princes unless they send for you" ; and another, "It is not well to eat cherries with the great." Thus not only disenchantment, but positive discomfort, if not worse, are foreshadowed here.

On the other hand, it is hazardous to try to assimilate the ideas of a genius, for their genesis lies beyond the ken of the average man. So also personal intercourse with a Bismarck, in whom loftiness of station and intellect were combined, was not without its dangers. It exposed those who 
enjoyed that privilege in a vulnerable spot: their vanity - the gratification of being honoured by the acquaintance of so eminent a man. Droll stories are told of the effect of Bismarck's company on some people thus distinguished by him.

If any of those who knew him escaped "giddiness," it was perhaps that, large as he loomed before them as a personality, he yet represented more than a mere individual, however eminent. He stood too high, too remote from a casual visitor to inspire affection. Affection demands at least a semblance of reciprocity, and one felt that, with all his courtesy and kindness, Bismarck's sympathies were far away, beyond the reach of us all. His thoughts were engrossed to the last by those elements which he was wont to describe as the "Imponderabilities" of life. According to the teaching of St. Paul, that which is visible shall pass away, but that which is invisible is eternal. To some of Prince Bismarck's admirers he himself represented a portion of that which is invisible - the imponderable sincerity - the veracity of an age-much of which was laid in the grave along with him.

As time rolls on the figure of the great servant of the State will be merged in the far broader conception of the Hero of a race, an embodiment of the Soul of a People-die Volksseele. The words he spoke as a teacher will probably be deemed mightier even than his deeds. His veracity, as 
above every gift of intellect, will be recognised clearer, far and wide. A pillar of fire in time of war, it shall shine forth in peace on the German heaven with a steady, beneficent light-that of a lodestar-for guidance always. Amen. 



\section{IN DEX}

Adlerberg, Count Peter, II 3

Albert, Prince, anecdotes of, 100-2

Alexander II., Emperor of Russia, 113

Alexander III., Emperor of Russia, I 3

Allers, C. W., I69

Antoine, an Alsatian deputy, $20 \mathrm{I}$

Arnim, Frau von, 183, 233

Army system, 60; efficiency of, II 6 Arnim, Count Harry, the case of, 125

Augusta, Empress, I63

Austria, Archduke Karl Ludwig of, 63

Austria, Commercial Treaty, 69, 108

Austria, Emperor Francis Joseph of, I09; on Prince Bismarck, 63 ; telegram on his birthday, 234

Autorite, L', "The End of the Ogre," 22

Bacon, Lord, I 35

Baden, Grand Duke of, 89

Balkan States, population of the, 240

Bancroft, George, portraits of, 30 , 106

Barschall, Frau F., 70

Bavaria, Prince Ludwig of, his visit to Professor Lenbach's atelier, I33 ; on Prince Bismarck, I 34

Bavaria, tribute from, 35

Beaconsfield, Lord, 105, 293 ; portraits of, 30, 106

Bebel, 94, 95
Becker, Herr, Oberbiurgermeister of Cologne, 185

Bellin, Frau, 55

Benningsen, Rudolph von, 246 ; on the Reichstag declining to congratulate Prince Bismarck, 220

Berlin, insurrection in, 55 ; Congress, I05; Prince Bismarck's recollections of, 199

Besser, Baroness Emma von, 70

Beust, Count, 127

Bismarck, Count August, 26 ; his treatment by the Russian Ambassador, 27 ; mode of riding, 33

Bismarck, Count Herbert, I0, I83 ; on the medals conferred on his father, 37 ; in London, 43; attachment of the villagers of Schoenhausen, 56 ; letters of invitation, 64, I33; his friendship for Lord Rosebery, 120 ; engagement, I 55 ; wedding, 177; duel when a Bonn student, 187 ; his Iron Cross of the second class, 190; on the death of his father, 267; appearance, 274 ; character, 275

Bismarck, Count William, 77, 157

Bismarck, Prince, first visit to, 9 ; his appearance, 10, 242, 283; on Imperial Germany, II ; his tree plantations, I2 ; favourite seat, I3; pistol practice, 13; his wife and daughter, I4; pipe, I5; system of farming, I6; on Motley, I8; his knowledge of nursery rhymes, 19; on drinking wine, 20; Prince 
Gortschakoff and Tyras, 20 ; newspapers, 22 ; on the Geestemünde election, 22, 24; cartoon, 22 ; Triple Alliance, 25; Signor Crispi, 26 ; his Schloss, 29, 32 ; portraits, $30,36,283$; head forester, 34 ; his hold upon the people, 34; tribute from Bavaria, 35; presents, 35-7, 43, 182, 263; telegrams, 37, 190, 234 ; hospitality, 39, I91 ; museum, 43 ; birthplace, 44 ; presented with the estate of Schoenhausen, 44; warlike ancestors, 49; crest, 5I, 75; room and hour of his birth, 52; grave of his brother, 54 ; marriage, 54 ; organises militia, 55 ; attachment of the villagers, 56 ; interest of the Austrians, 63 ; at Varzin, 65 ; on horseback, 65 ; his son-in-law, 66 ; favourite fish, 67 ; feat of oyster-eating, 68 ; liking for Lenbach, 68; on the Neue Freie Presse, 69; his English and French, 73 ; study, 74, 262; favourite books in the Bible, 74; motto, "In Trinitate robur," 75 ; investment in Russian State Bonds, 75 ; bedroom, 76, 262, 273; on length of life, 76 ; gift of a walking-stick, 77-9; love of country life, 80 ; his vehemence, 82 ; on his dismissal from office, 83 ; the lack of character, 83 ; dislike of Liberalism, 84; Irish Home Rule, 84; on the English fashion of drinking water, 85 ; the freemasonry of royalty, 87 ; patriotic conduct of the German sovereigns, 88 ; view of Socialism, 89-93; his "objectivity," 93 ; antipathy to Bebel, 94; Insurance Laws, 95 ; attempts on his life, 96 ; on the dignity of King William, 97; sleeplessness, 97, 125; neuralgic pains, 97, 239, 242, 256; on the Empress Frederick, 98; Duke Ernest of Coburg's pamphlet, 99; Prince Consort, I00-2 ; King of Denmark, I03; the campaign of 1866, I03;
Berlin Congress, I05; relations with Americans, 106; friendship with Motley, I06; on Count Caprivi's policy of conciliation, I08; Commercial Treaty with Austria, I09; treatment of the French, IIO; attitude towards Russia, IIO; on the Poles, III ; his visit to St. Petersburg, I12, policy of Russia, II3-I 5; Emperor Alexander III., I I4; Moltke, II6; the Army, I 16 ; on his own achievements, II 7 ; favourite sayings, II9; on Lord Rosebery, 120 ; relations with England, I2r ; on the cession of Heligoland, I2I ; cost of defending, 122; colonial expansion, 123 ; Major von Wissmann, I24 ; on the case of Count Arnim, I25 ; on an incident of Court life, 126; lack of interest in individuals, 126 ; on Count Beust, 127; Carlyle, 128; Max Müller, I28; his moderation, 128; character, 129, I93 ; intense melancholy, I29; affinity to Lord Clive, 132; his Russian leather top-boots, I34; on the authorship of Shakespeare's plays, 135; his opinion and trust in Lothar Bucher's judgment, 136,151 ; on the health of his wife, I4I ; the character of the Russians, I4I ; sentiments towards Mr. Gladstone, 152 ; on the mixed character of political races, 155; at the gathering of the "Waldfest," I 57-9; on German champagne, I60; a book containing libels, $16 \mathrm{r}-3$; delicacy of feeling, 163, I93; triumphant progress of his journey to Vienna, 167,168 ; at Kissingen, I70; on the Jews, I75; action of the Government, I75; Count Caprivi, 175; on his stay in Vienna, I77; advice to Prince Ferdinand of Bulgaria, 179; celebrations of his birthdays, 182, 219 ; visitors, 183 ; deputations, I $84,222-228,239$; floral tributes, 185, 222 ; deputation of students, 
185, 228-33 ; "Veterans' Union," 185,187 ; on the Schleswig-Holstein question, 188; size of his pencils, 191 ; reports of his wealth, 191 ; kindness of heart, 193 ; isolation, 194, 269; on Count X., I96 ; the Middle-European time-table, 196 ; observance of Sunday, 197 ; his anecdotes of Frederick the Great, 198; recollections of Berlin, 199; of England and France, 200; on the intended visit of Gambetta, 201 ; number of letters, 202, 234 ; tribute from Bohemia, 203; death of his wife, 205; publication of his Love Letters, 205 ; on the action of the Reichstag, 220; deputation of the Hamburg Senators, 222 ; degree of Doctor conferred by all the Universities, $223 n$. ; deputation of the professors, 223-8; address to the students, 230; topics of conversation, 236; his view of principles, 237 ; on the assassination of Stambulow, 240; engraving of, 241 ; on the price of wine, 243 ; cigars, 244; his opinion of President Krüger, 247; Mr. Rhodes, 247 ; the Jameson Raid, 248 ; his sympathy with the Boers, 249; on the conquest of the Soudan, 251 ; Turkey, 25I ; Crete, 252; opinion of Lord Salisbury, 252 ; present from the Sultan, 253; illness, 254, 256; death, 257-60 ; position in death, 261 ; features, 262, 264, 284; coffin, 263, 266; funeral service, 267; mausoleum, 270; retention of his faculties, 277-80; the Bismarck Hetze of 1891-2, 278; retirement, 280-3 ; attachment to his country, 281 ; popularity, 283; his hands, 285 ; size of his feet, 286 ; dress, 286 ; physical strength, 287 ; voice, 288 ; charm of his manner, 289 ; freedom from class prejudice, 290; early training, 291; noble birth, 291; antipathies and preferences,
293 ; his mother, 294 ; sympathy, 295; no taste for music, 295; dislike of dogmatism, 296 ; religious feeling, 296; mode of speaking of the dead, 297; taste in reading, 297 ; veracity, 300.

Bismarck, Princess, 14; ill-health, 14; on the messages received by Prince Bismarck, 37 ; at Varzin, 66 ; sleeplessness, I43; fondness for music, 144; at Kissingen, I 76 ; visit to Munich, I77; her death, 205 ; character, 206 ; extent of her reading, 208; lack of veneration for rank, 209; reminiscences of her wedding tour, 210 ; simplicity in the style of living, 210-12; unceasing care for-her family and guests, 213 ; sufferings, 214 ; perspicacity, 214; dislike of the snob, 215 ; descent, 215 ; strong feelings, 216; keen sense of humour, 217

Blackie, Professor J. S., 5

Bleichroeder, 76

Blowitz, Chevalier de, his share in the Berlin Congress, 105

Blumenthal, 279

Boers, sympathy with, 249

Bohemia, letter of congratulation on Prince Bismarck's birthday, 203

Bonn University, deputation of students, 185

Boots, Russian leather, 134

Bora, Katherine von, 22

Braddon, C., 208

Breidenbach, 208

Bucher, Lothar, Privy Councillor of Legation, 136; French origin, 137 ; appearance, 138 ; character, 138 ; study of astronomy, 139 ; intimacy with Lassalle, $\mathrm{r} 39$; "Letters from Abroad,"139; Der Parliamentarismus Wie Er Ist, 140 n., 149; his refusal to pay taxes in 1848,141 ; on the memoirs of Prince Bismarck, 146 ; on the ingratitude of his treatment, 146; pessimism, 147; on the result of his dismissal, 147; animosity towards Mr. Gladstone, 148; 
his study of England's social and political institutions, I49; dislike of them, 150 ; his volume of essays, I 51 ; illness and death, I53; valuable services, I53; acute perception, 154

Budapest, 62

Bulgaria, Prince Ferdinand of, advice from Prince Bismarck, I79

Bülow, Hans von, r8o

Caprivi, Count, his policy of conciliation, I08; treatment of Herr von Sybel, I65; character, I75; succeeds Prince Bismarck, 282

Carlweiss, 208

Carlyle, Thomas, extract from his History of the French Revolution, 5 ; autograph letter from Prince Bismarck, 128; denunciation of Mr. Gladstone, 149

Carolath, Prince, 246

Cassagnac, Paul de, 22 ; on Prince Bismarck's retirement, 220

Chamberlain, Mr., 251

Chamfort, his aphorism, I3 I

Champagne, German, 160

Cherbuliez, Victor, Olivier Maugant, $3 \mathrm{I} n$.

Chrysander, Dr., secretary to Prince Bismarck, I4 ; his work, 202, 234

Cigars, price of, 244

Clive, Lord, 132

Coburg, Duke Ernest of, his pamphlet on Mitregenten Und Fremde Hände in Deutschland, 99 ; antipathy for Lord Palmerston, 100

Cohen, his attempt on the life of Prince Bismarck, 96

Conrad, E. Werner, 208

Constantinople, 114, 253

Crest, the Bismarck, 5I, 75

Crete, 252

Crispi, Signor, 26

Daudet, Alphonse, 46

Delbrück, Professor Hans, 246

Denmark, King Frederick VII. of, 103
Donnersmarck, Count Henkel von, 222

Dresden, cost of the Central Railway Station, 243

Dufferin, Lord, on the character of the Russians, $142 n$.

Dürkheimer, 243

Edward VII., King, his telegram on Prince Bismarck's birthday, 234

Egypt, Khedive of, $192^{\circ}$

Elbe, valley of the, 47 ; system of dykes, $55 n$. ; inundations, $56 n$.

Engel, Dr. Ernst, 6, 7

England, fashion of drinking water in, 86; Socialism, 93 ; cession of Heligoland, I21 ; colonial power, 123; social and political institutions, 149; impressions of, 200; relations with Germany, 245, 254

Erlangen, University of, nominates Prince Bismarck Doctor of Law, $223 n$.

Farming, system of, I6

Fehrbellin, Battle of, 50

Fir tree plantations, I2

Fischbeck village, 47

Fish, various kinds of, 67

France, Prince Bismarck's policy towards, I Io

Frederick, Empress, 97 ; her attachment for England, 98; telegrams on Prince Bismarck's birthday, I90, 234

Frederick the Great, anecdotes of, 198

Freisinnige Zeitung, 203

Freytag, Gustav, 49

Friedericia, siege of, 103

Friedrichsruh, visits to, 9, 134, 155, 182, 239, 256, 270; the Schloss, 10; dining-room, 14 ; the Forest, 16; drawing-room, 21 ; pictures, 21 ; visitors' rooms, 29 ; photographs, 29 ; staircases, 30 ; sim. plicity, 31 ; space, 32 ; position, 32 ; fête at, on the celebration of 
Prince Bismarck's birthday, 22I ; management of the telegraphic service, $233 n$.

"Friedrichsruh, Drei Tage in," $63 n$.

Froude, Professor J. A., on Bismarck, 5 ; gift of a walking-stick, 77

Frundsberg, Georg von, his words to Luther at the Diet of Worms, 2

Galitzin, Prince, anecdote of, 238

Gambetta, his intended visit to Prince Bismarck, 201 ; estimate of his parliamentary colleagues, 201

Gastein, 127

Gautsch, Herr von, 63

Geestemiunde election, 22, 24

Geffcken, the case of, 126

Gehlsen, I63

George IV., King, I03

Germany, character of the people, 3, I30; the Thirty Years' War, 47 ; lack of "backbone," 83 ; type of the Streber, $8 \mathbf{3}$; patriotic conduct of the sovereigns, 88 ; growth of Socialism, 89 ; the outcome of industrialism, 94 ; exchanges Zanzibar for Heligoland, 122 ; cost of defending, I22; colonial expansion, 123; power of the priesthood, 148; mixed character of the races, 155 ; liberty of the Press, 162; Reichstag declines to congratulate Prince Bismarck, 220 ; relations with England, 245, 254

Giessen, University of, proclaims Prince Bismarck Doctor of Theo$\operatorname{logy}, 223 n$.

Gladstone, Herbert, ${ }^{52}$

Gladstone, W. E., his policy towards Ireland, 83; temperament, $\mathrm{I}_{30}$; animosity of Lothar Bucher, 148 ; sentiments towards Prince Bismarck, 152; his " principles," 237

Gladstone, An Apology for the Life of the Right Hon. W. E., I49n.

Gneist, Professor Rudolph von, his admiration for England's political institutions, 149
Goethe, his birthplace, 46 ; temperament, 131 ; death, 264, 279

Gortschakoff, Prince, his rencontre with Tyras, 20 ; temperament, I3I

Göttingen, University of, nominates Prince Bismarck Doctor of Law, $223 n$.

Grant, General, portraits of, 30, 106 ; at Berlin, 107

Halle, University of, confers on Prince Bismarck Doctor of Philosophy, $223 n$.

Hamburg, 257, 269; illuminations in in honour of Prince Bismarck's birthday, $22 \mathrm{I}$; deputation of senators, 222

Hamburger Nachrichten, 63, 245

Hammerinuhle Station, 65

Harper's Magazine, article on the relations between England and Germany, 254

Harte, Bret, 208

Hatzfeldt, Count, 216

Heligoland, cession of, 121 ; cost of defending, 122

Helmerding, Carl, 39

Hesse-Darmstadt, Grand Duke of, 104

Hödel, his attempt on the life of Emperor William I., 96

Holmes, O. W., on the effects of advancing age, 276

Hopfen, Hans, 208

Hoyos, Countess George, 157

Hoyos, Countess Margaret, her engagement, I 55

\section{Imperial Germany, 7, I I}

Innocent III., Pope, his extermination of the Albigenses, 89

Insurance Laws, 95

Irish Home Rule, 82

Izzet Bey, Second Secretary to the Sultan of Turkey, 253

Jameson Raid, the, 248 
Jena, Battle of, 48 ; University of, confers degree of Doctor of Medicine on Prince Bismarck, $223 n$.

Jennings, L. J., Mr. Gladstone: a Study, I 49

Jokai, Maurus, 208

Junker, 208

Ke dell, Herr von, Erinnerungen, I 29 n, , 205, 295

Kissingen, visit to, 170 ; battle of, in 1866, 171; baths of, 171; "Obere Saline," I7 1

Kleist-Retzow, Herr von, 104

Körner, Theodor, 39 , 48

Krïger, President, 247

Kullmann, his attempt on the life of Prince Bismarck, 96

Lange, the head forester, 34

Lassalle, Ferdinand, 95 ; his intimacy with Bucher, 139

Lenbach, Franz von, 64, 66; his portraits of Prince Bismarck, 36, 70, 241; intimacy with him, 68; gift of humour, 68; visit from Prince Ludwig of Bavaria, I33; from Prince and Princess Bismarck, 177; at Friedrichsruh, 182, 222; his sketch of Countess Herbert Bismarck, 183; proposes Prince Bismarck's health, 190; on the reports of his wealth, 19I; his character, 193 ; on his death, 264

Letters, number of, received by Prince Bismarck, 202, 234

Levi, Hermann, at Friedrichsruh, 201

Lewald, 208

Li Hung Chang, 252 ; picture of, 263

Liberation, War of, 50

Liebknecht, 95

Lindau, Paul, 208

Loë, Legationsrath von, 125

Loescher and Petsch, their profile photograph of Prince Bismarck, 284

Louis XIV., his revocation of the Edict of Nantes, 89

Louis Philippe, 20I
Luther, Dr. Martin, 2, 2 I

Liitzow, Major von, benediction of his Free Corps in the church of Schoenhausen, 48

Mahmud, Sultan, portrait of, 253

"Marena," 67

Marbot, General, his Memoirs, 297

Marlitt, 208

Marmont, Marshal, his Reminiscences, 297

Marx, 95

Mascagni, Cavalleria Rusticana, 144 Mathew, Father, 87

Menzel, A. von, 43

Merck, Baron von, 157

Merck, Baroness von, 18, 157, 163; her intimacy with Prince and Princess Bismarck, 142; study of astronomy, 143

Meyer, Herr, 237

Middle-European time-table, introduction of the, 196

Mitregenten Und Fremde Hände in Deutschland, authorship of, 99

Mollhausen, 208

Moltke, Count, 65, 76, 116 ; his death, 42, 279; temperament, 130 ; in Turkey, 253; "undress" uniform, 283; his mother, 294

Motley, J. L., his character, 18; friendship with Prince Bismarck, I06; correspondence of, $129 \boldsymbol{n}$.

Motto, the, "In Trinitate robur," 75 Müller, Professor Max, 128

Munich, 177

Napoleon I., 48

Neue Freie Presse, 63, 69

New York Herald, 233 ; special correspondent of the, 253

Nicholas I., Emperor of Russia, 112

Niemann, 208

Nietzsche, quotation from, 172

Nobiling, his attempt on the life of William I., 97

Norddeutsche Allgemeine Zeitung, 175 
Olmütz, I 18

Oysters, number of, eaten by Prince Bismarck, 68

Palmerston, Lord, his jealousy of foreign influence, 100; temperament, I3I

Paris Exhibition of 1867,104

Petersburg, St., I 12

Pfleiderer, Professor, his address on Prince Bismarck's birthday, 223; concluding words, 227

Phelps, Mr., photograph of, 30

Poles, number of, III ; character, 112

Postal service, number of letters and parcels received by Prince Bismarck, 235

Prussia, Queen Louise of, 48

Pultawa, 50

Rantzau, Count, 66 ; on the number of deputations received by Prince Bismarck, 239 ; on his illness, 254 ; letter on the article dealing with the relations between England and Germany, 255

Rantzau, Marie, Countess, I4 ; repeats English rhymes, 19; at the "Waldfest" gathering, I 57

Rawson, Sir Rawson W., 62

Reichenbach, M. von, 208

Reichsglocke, 163

Rendel, Lord, 152

Reservemann, a, 59

Reuss, Princess, her welcome to Prince Bismarck, I 78

Rhodes, Mr., 247

Rhymes, English, 19

Richter, Eugen, 29I

Roon, Count, 65, I 16

Rosebery, Lord, his friendship with Count Herbert Bismarck, 120

Rothschilds, his mode of conducting business, 237

Roumania, King of, his telegram on Prince Bismarck's birthday, 234

Rudolsbad, I68
Russia, Prince Bismarck's attitude towards, 110; policy towards Constantinople, I I4; character of the people, I4I

Saale River, 172 ; valley, I 76

Sachsenwald, 163

Sadowa, anniversary of the victory of the, 173

Salisbury, Lord, 252

Saxon Forest, 9, 14I

Saxony, King Albert of, 89

Schaffgotsch, Count, his Schloss at Warmbrunn, 75

Schaper, Professor, 223

Scheibler, Dr., his lines on Prince Bismarck, $3^{8}$

Schelling, on the insurrection in Berlin, 55

Scherr, Johannes, 49

Schill, Major, his Free Corps, 50

Schlawe, 8I, 201

Schleiermacher, 27 I

Schleswig-Holstein question, 188

Schoenhausen, 256; visit to, 43 ; museum, 43 ; birthplace of Prince Bismarck, 44; foundation, 44 ; records of the village, 46 ; plundered by the French, 48 ; benediction of the reconstituted Free Corps of Major von Litzow, 48 ; population, 50; Schloss, 5I ; cannon, 53; grounds, 53 ; attachment of the villagers, 56 ; character, 57 ; church, $5^{8}$; monument, $5^{8}$; post office, $5^{8}$

Schopenhauer, Arthur, anecdote of, 68

Schouvaloff, Count, 27

Schwartz, his gift to Prince Bismarck, 37

Schwarzenberg, Prince, $118 n$.

Schweninger, Dr., 15, 76, 141, 171 ; on the health of Prince Bismarck, 18 J, 256; his recovery from an illness, 183 ; in Norway, 239 ; on the death of Prince Bismarck, 258-60; on his character, 268 
Shakespeare, W., quotation from the Midsummer Night's Dream, 83; from Hamlet, 135 ; controversy on the authorship of his plays, 135

Silesia, 62

Smith, Professor Goldwin, 5; his testimony to Prince Bismarck, 6

Socialism, the growth of, 89; the ethical side, 90 ; outcome of German industrialism, 94

Soudan, conquest of the, 25 I

Spinoza, his birthplace, 46

Stambulow, his assassination, 239

Sterlet, 67

Stinde, 208

Students, deputation of, 228; number, 229; character, 230; address from Prince Bismarck, 230; their gift, 23 I

Stuttgart, Deutsche Union Verlag, 169

Sunday, observance of, 197

Sybel, Professor Heinrich von, Die srïndung des Deutschen Reichs, 164; his reception at Friedrichsruh, 164 ; treatment by Count Caprivi, 165 ; on the wonders of the heavens, 166

Tangermünde, 46, 48

Tankard, a silver, 37

Telegrams, number of, received by

Prince Bismarck, 182, 190, 234, 235

Telegraphic service, management of, $233 n$.

Tench, 67

Tenniel, Sir John, a reprint woodcut of his cartoon "Dropping the Pilot," 30

Thiers, M. Adolphe, 20I; his temperament, 133

Thirty Years' War, result of the, 47

Tilsit, Peace of, 50

Time-table, Middle European, introduction of the, I96

Treitschke, Herr von, on the fate of Prince Bismarck, 168
Triestine Irredentists, 26

Triple Alliance, 25

Tübingen, University of, raises Prince Bismarck to the distinction of Doctor of Political Science, $223 n$.

Turkey, $25 \mathrm{I}$

Turkey, Sultan of, his present for Prince Bismarck, 253

Tyndall, Professor, his dictum on Mr. Gladstone, 149

United States, Socialism in, 92

Universities, German, deputation of professors, 223-8

Vaillant, Marshall, 104

Varzin, visit at, 64 ; Schloss, 66, 7I ; grounds, 71 ; life at, 72 ; schools, $8 \mathrm{r}$; absence of servility. in the people, $8 \mathrm{I}$

Veterans, deputation of, 187

Vienna, International Statistical Congress, 62 ; hospitality, 62

Vitzthum, Count, 228

Volksboten, 37

Vollmar, Herr von, the Bavarian Socialist, 91

Voss, 208

Wagner, Richard, element of tragedy in his music-dramas, 132

Waldersee, Count, 221

" Waldfest" gathering, I 57

Waldzedlitz, 208

Walking-sticks, number of, 77

Wallichs, Dr., 188

Warmbrunn, Schloss at, 75

Waugh, Arthur, his translation of the lines on Prince Bismarck, $3^{8} n$.

Weimar, Bernhard von, 49

"Werder, Hans," 70

Wesel, 50

Westkirch, 208

Wichert, 208

Wildenbruch, Ernst von, his lines on Prince Bismarck, 38

William I., Emperor, his despondency in the days of the "Conflict-Zeit," 


\section{IN DEX}

82 ; attempts on his life, 96,97 ; innate dignity, 97 ; his portrait at Friedrichsruh, 209; death, 279

William II., Emperor, on his sister's preference for England, 99; on German champagne, 160 ; his telegram to Prince Bismarck, 220; to President Krüger, 246; at the funeral of Prince Bismarck, 267

Windhorst, 93

Wine, Dürkheimer, 243 ; price of, 244
Wissmann, Major von, his supersession in East Africa, 124

Wolff, Julius, 208

X., Count, 195

Zanzibar, cession of, $122 \%$

Zanzibar, Sultan of, 192

Zitzewitz family, 8I

Zola, Emile, his works, 297 
PLYMOUTH

WILLIAM BRENDON AND SON

$+$.

\section{PRINTERS}

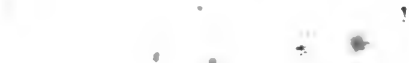

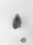




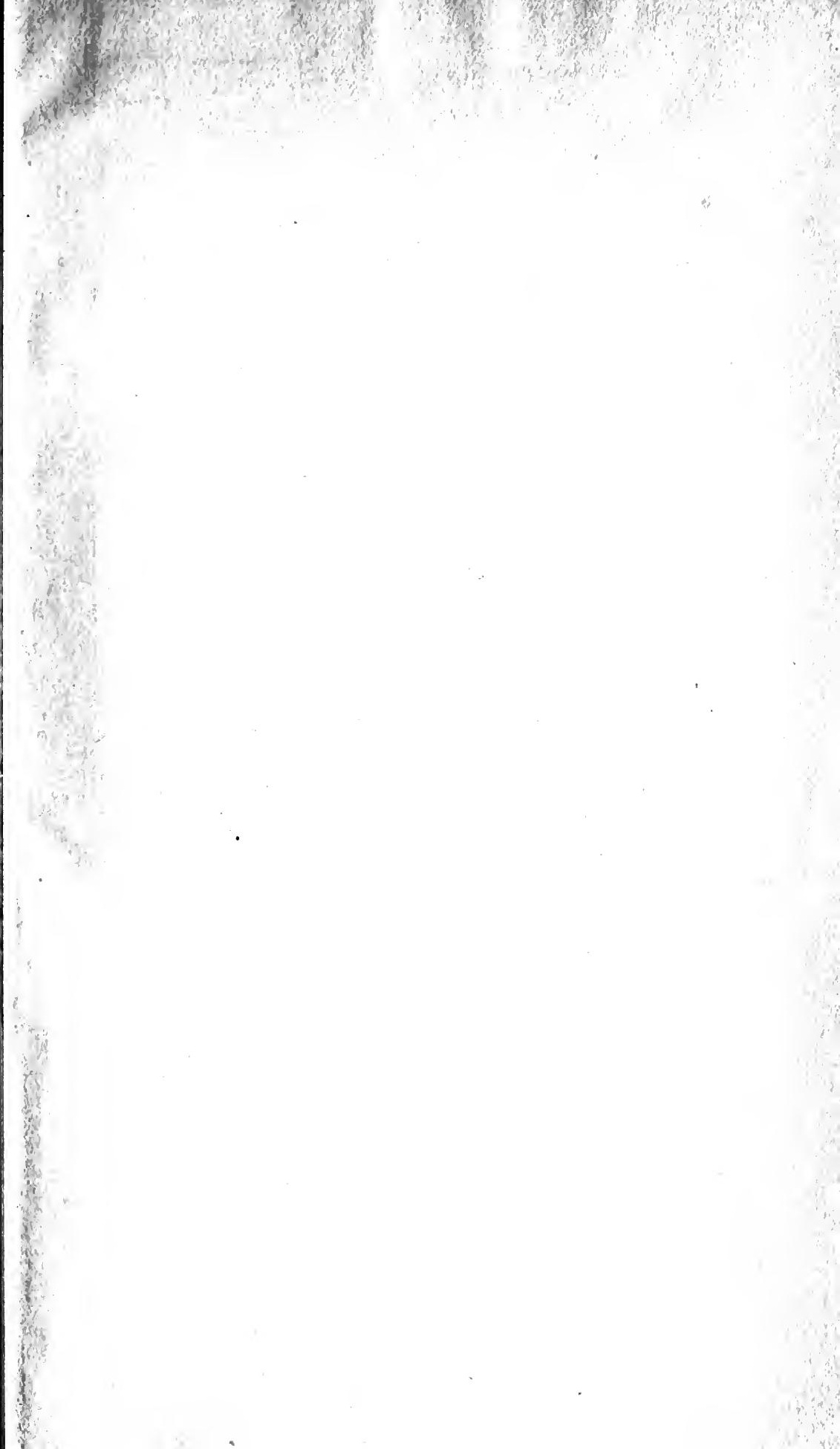


THIS BOOK IS DUE ON THE IAST DATE STAMPED BELOW

\section{AN INITIAL FINE OF 25 CENTS} WILL BE ASSESSED FOR FAILURE TO RETURN THIS BOOK ON THE DATE DUE. THE PENALTY WILL INCREASE TO $5 O$ CENTS ON THE FOURTH DAY AND TO \$1.00 ON THE SEVENTH DAY OVERDUE.

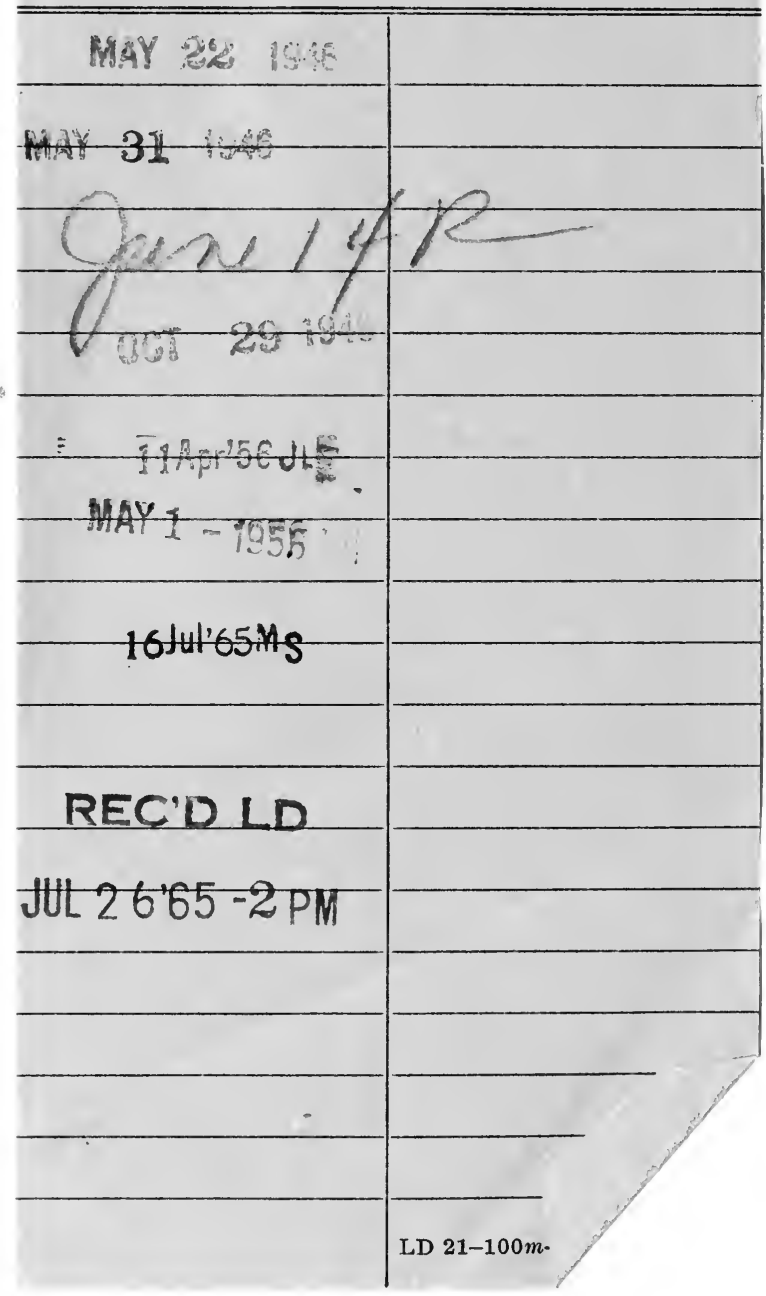



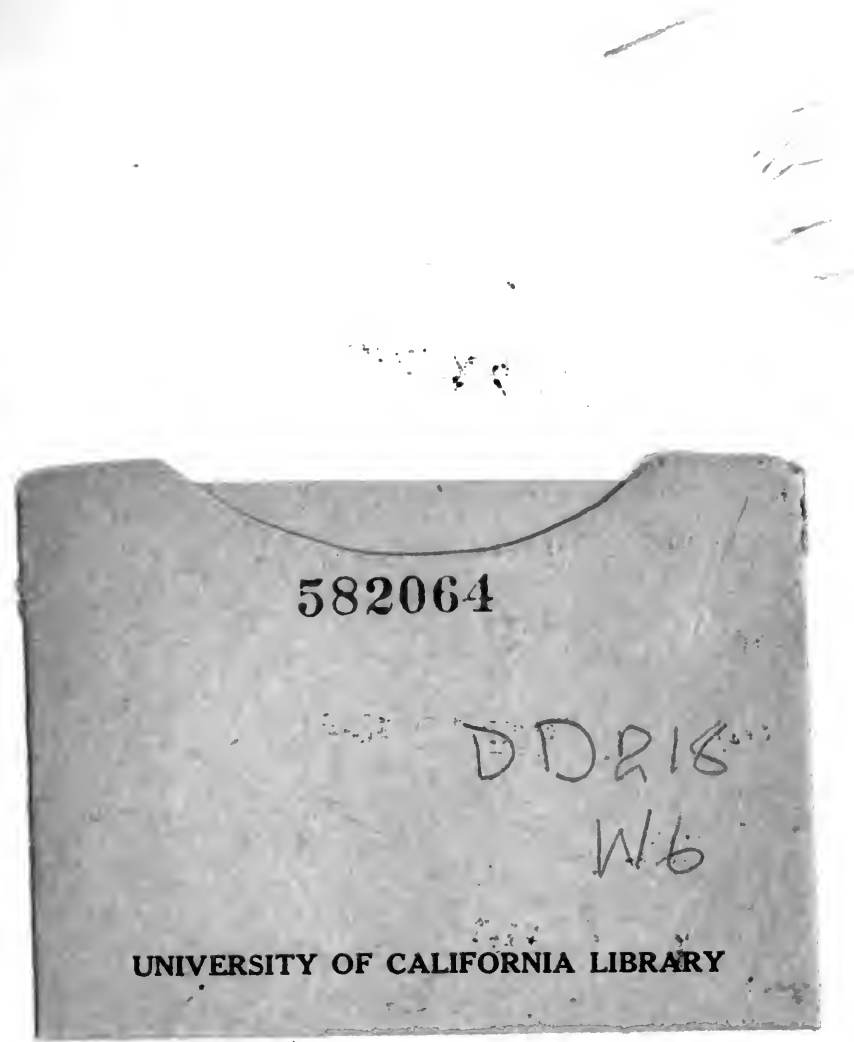
